\title{
Insights into Gastrointestinal Virome: Etiology and Public Exposure
}

\author{
Islam Nour ${ }^{1}{ }^{1}$, Atif Hanif $^{1}$, Martin Ryan ${ }^{2}$ and Saleh Eifan ${ }^{1, *}$ \\ 1 Botany and Microbiology Department, College of Science, King Saud University, Riyadh 11451, Saudi Arabia; \\ inour@ksu.edu.sa (I.N.); ahchaudhry@ksu.edu.sa (A.H.) \\ 2 Biomedical Sciences Research Complex, School of Biology, University of St. Andrews, \\ St. Andrews KY16 9AJ, UK; mdr1@st-andrews.ac.uk \\ * Correspondence: seifan@ksu.edu.sa
}

Citation: Nour, I.; Hanif, A.; Ryan,

M.; Eifan, S. Insights into

Gastrointestinal Virome: Etiology and

Public Exposure. Water 2021, 13, 2794

https://doi.org/10.3390/w13192794

Academic Editor:

Alessandra Marzadri

Received: 1 July 2021

Accepted: 4 October 2021

Published: 8 October 2021

Publisher's Note: MDPI stays neutral with regard to jurisdictional claims in published maps and institutional affiliations.

Copyright: (c) 2021 by the authors. Licensee MDPI, Basel, Switzerland. This article is an open access article distributed under the terms and conditions of the Creative Commons Attribution (CC BY) license (https:// creativecommons.org/licenses/by/ $4.0 /)$.

\begin{abstract}
Recycled wastewater is widely used owing to the potential shortage of water resources for drinking purposes, recreational activities, and irrigation. However, gut microbiomes of both human beings and animals negatively affect this water quality. Wastewater contamination is continuously monitored, using fecal contamination indicators or microbial source tracking approaches, to oppose arising enteric infections. Viral gastroenteritis is considered a principal manifestation of waterborne pathogenic virome-mediated infections, which are mainly transmitted via the fecal-oral route. Furthermore, acquired enteric viromes are the common cause of infantile acute diarrhea. Moreover, public exposure to wastewater via wastewater discharge or treated wastewater reuse has led to a significant surge of public health concerns. In this review, we discussed the etiology of waterborne enteric viromes, notably gastrointestinal virus infections, and public exposure to municipal wastewater. Conclusively, the early human virome is affected mainly by birth mode, dietary behavior, and maternal health, and could provide a signature of disease incidence, however, more virome diversification is acquired in adulthood. A multi-phase treatment approach offered an effective means for the elimination of wastewater reuse mediated public risks. The insights highlighted in this paper offer essential information for defining probable etiologies and assessing risks related to exposure to discharged or reused wastewater.
\end{abstract}

Keywords: virome; wastewater; etiology; viral gastroenteritis; exposure

\section{Introduction}

Virome diversity accounted for approximately 1031 members worldwide, including bacteriophages, as the major division according to a ten-fold diversity evaluation compared to their bacterial hosts' diversity [1]. Likewise, phage community dominates the early human enteric virome, along with the bacterial communities' expansion acquired by maternal-mediated vertical transmission and after weaning $[2,3]$. On the other hand, enteric viruses in infants are minimally acquired from their mothers [4], however, the enteric viromes mostly persist after the first two years [2,5]. Several enteric viruses could transfer to infants, and even children, via maternal transmission, through direct exposure, or through the use of contaminated water, such as hepatitis E virus (HEV) and hepatitis A virus (HAV) causing gastroenteritis or, in severe cases, fulminant hepatitis [6-8].

However, adenovirus, rotavirus, norovirus, hepatitis A virus, and astrovirus represent the most commonly acquired enteric viruses and contribute to virome shaping in its early phases [6,9-12]. Moreover, these viruses are of high persistence in various water environments. For example, noroviruses can survive in ground water for 1266 days at $25^{\circ} \mathrm{C}$ with $1.76 \log _{10}$ reduction [13]. However, adenoviruses can last for 36 and 132 days at $20^{\circ} \mathrm{C}$ and $4{ }^{\circ} \mathrm{C}$, respectively, and are associated with a $1 \log _{10}$ reduction [14]. Rotaviruses can also persist in fresh water and drinking water for 10 [15] and 64 [16] days, respectively, at $20^{\circ} \mathrm{C}$ with $2 \log _{10}$ reduction. 
People are frequently exposed to wastewater via surface water usage, toilet flushing, recreation water, and wastewater-or greywater-dependent irrigation [17-21]. Most commonly occurring enteric viruses are self-limiting, whereas their infection risk is determined by the prevalence of infectious viral particles in the appropriate environmental condition, since some enteric viruses are significantly influenced by seasonal variation (e.g., rotavirus favoring late autumn and early winter [22]) or their prevalence in water environments that people are exposed to. For instance, the prevalence of HAV was found to be higher in raw water $(16 / 27 ; 59 \%)$, than in treated water $(5 / 26 ; 19 \%)$ [23].

Wastewater discharge to surface water resources imposes public health concerns and directly affects water resources, causing both enteric and non-enteric diseases, especially with the recent COVID-19 pandemic [24-26]. On the contrary, wastewater reuse was proposed mainly because of the shortage of water supplies $[27,28]$. This demanded technical solutions for reuse of treated water for both non-potable uses, such as irrigation, with reported limitations (e.g., alterations of soil physicochemical parameters, microbiota [29], soil fertility, and subsequent productivity [21] and soil $\mathrm{pH}$ [29]) to be considered and de facto wastewater reuse associated with raised concerns (e.g., increased drinking water risks in case of wastewater effluent in source water [30]). Integration of these technical solutions with a water safety plan (WSP) could offer organized management solutions for limitations and concerns. Thus, the current review highlighted the etiology of enteric viromes in various water environments and the associated concerns related to public exposure to municipal wastewater via wastewater discharge or treated water reuse.

\section{Enteric Virome in Infants}

The microbiome is established as early as the gestation period, and develops into a steady state as the individual reaches early adulthood [2,31-34]. Infant microbiomes were shown to be influenced by various factors involving birth mode, gestational age, antibiotic usage, geographical location, lifestyle, diet, and age [35-37]. For instance, a greater virome diversity was observed in spontaneous vaginal delivery (SVD) than in caesarean section (CS) [38]. Moreover, microbiome diversification during the early months after birth was found to be followed by a secondary expansive phase owing to diet alterations that occur after weaning $[2,3,39]$. Furthermore, microbiome composition of the infants' gut is linked to that of the maternal gut $[4,40,41]$. However, it was demonstrated that vertical transmission of the virome was considerably lower than that of bacterial microbiome [4].

Interestingly, antibiotic usage acts as a stressor, causing microbiome imbalances that are reported to cause sepsis in newborn infants by vertical transmission [42]. Antibiotic treatment reduces both the size and diversity of the bacterial community, initiates pro-phage activation, and enriches phage-encoded antibiotic resistance genes that further influences the prokaryotic microbiome, which is associated with long-term implications [37,43-45]. Thus, such influences on the microbiome via these trans-domain interactions can be associated with probable metabolic deficiencies and inflammatory conditions [46-49]. On the other hand, the infant virome is affected by dietary behavior and could serve as a signature of malnutrition. For instance, members of the Anelloviridae and Circoviridae were found to discriminate between both healthy twin pairs and twin pairs developing malnutrition [50].

Although the microbiome is acquired during pregnancy or even at birth, the gut virome develops postnatally, since the meconium was found to lack any virus-like particles (VLPs) [51]. However, VLP numbers begin to surge to about $10^{8}$ per $\mathrm{g}$ feces in the first birth week, along with the primary colonizers that arise from dietary and maternal sources in addition to the surrounding environment [52]. Consequently, the infantile virome expands and includes significant shifts in the phage community along with age because of the expansion and diversification of the bacterial communities [2]. Moreover, enteric virus communities in infants, accounting for $15 \%$, are acquired from their mothers [4]. The virome peak is reached at adulthood, displaying persistent viruses of about $80 \%$ that persist for $>2.5$ years [2,5]. Moreover, eukaryotic viruses, including adenovirus, herpes simplex virus, 
cytomegalovirus (CMV), human parvovirus B19, enterovirus, respiratory syncytial virus, and Epstein-Barr virus, were characterized from healthy mothers' amniotic fluid, while neonates were healthy [53]. Furthermore, placental and vaginal transmission of viruses, comprising of $\mathrm{HIV}$, influenza, hepatitis, CMV, rubella, and herpes zoster virus, were also detected, rendering extra evidence of maternal-mediated infantile virome modification [54]. This eukaryotic virome encompasses these conventional pathogenic viruses and viruses of unidentified host interactions. Despite the presence of these classical pathogens, infected hosts can remain asymptomatic.

On the other hand, waterborne enteric viruses, further, nourish the infantile virome either through maternal-based vertical transmission [55] or ingestion of contaminated water or infant formula, as reported elsewhere [56]. For instance, acute maternal HAV infection could result in infant infection during the last trimester or the postpartum period [6]. Moreover, piped drinking water crossing sewage channels in India led to higher hepatitis E virus incidence in mothers, that was then vertically transmitted to fetuses [7]. Subsequently, two fetuses were aborted and four pre-matured babies were delivered [8]. Therefore, an obvious relationship between the gastrointestinal virome in infants and waterborne diseases or enteric viruses in wastewater is well-established and tightly linked to community behavior, life style, and infection risk via direct or indirect contact with contaminated water.

\section{Viral Etiology}

Viral gastroenteritis is mainly transmitted by the fecal-oral route. Currently, five common groups of viruses account for the most frequently occurring acute diarrheal cases worldwide: adenovirus, rotavirus, norovirus, hepatitis A virus, and astrovirus.

\subsection{Adenovirus}

Adenoviruses are members of the family Adenoviridae and the genus Mastadenovirus, comprising of more than 80 human serotypes [57]. Human adenoviruses are non-enveloped icosahedral particles with a double-stranded linear DNA genome of $\sim 34-36 \mathrm{~kb}$ [58]. They are currently grouped into seven human adenovirus species (A-G), alongside novel adenovirus types that are continuously emerging $[59,60]$. Virus types were identified in cross-neutralization assays as serotypes up to type 51, however a genotype designation was used for the more recent types based upon phylogenetic analyses of genes encoding the major capsid proteins [61].

Adenovirus infections can lead to a wide spectrum of clinical symptoms. Gastrointestinal infections are commonly caused by subgroup A, D, and F, while subgroup B is the main cause of infections of the lungs and the urinary tract. Subgroups $C$ and $E$ are, however, mainly related to infections of respiratory tract. Amongst subgroup F, serotypes 40 and 41, with serotype 31 of subgroup A, are mainly associated with gastroenteritis [62]. Adenovirus infections are mostly self-limiting, with the exception of immunocompromised individuals. However, a strain of adenovirus 14 that emerged previously resulted in a fatal respiratory disease in healthy personnel [63].

Human adenoviruses (HAdV) are specific to humans even though adenoviruses infect a range of animals. In domestic sewage, HAdV existed in notably high concentrations and their seasonal variability was insignificant [64-66]. As with most enteric viruses, adenoviruses are more persistent in various water environments, including lakes, irrigation water, and treated sewage (Table 1), than the currently used fecal indicator bacteria $[67,68]$. For instance, adenovirus was detected in rivers (18-100\%), recreational water (40-93.1\%), raw sewage water $(0.4-100 \%)$, and treated effluents (25-100\%, except for that reported in earlier study conducted in Tunisia) as shown in Table 1. Moreover, adenovirus was of the highest concentrations, estimated at $9.8 \times 10^{8} \mathrm{GC} / \mathrm{mL}$, in treated water influents and in treated effluents, at $4.9 \times 10^{8} \mathrm{GC} / \mathrm{mL}$, in Italy. HAdV was of the highest frequency $(100 \%)$ in raw sewage water in all countries, except for the U.K. and Italy, wherein the encountered frequency was $90 \%$ and $96 \%$ in the same source, respectively. However, the highest HAdV 
concentration was obtained from lagoons and beaches in Brazil ( $\left.10^{9} \mathrm{GC} / \mathrm{L}\right)$. Furthermore, adenoviruses are highly resistant to UV light and this significant resistance might be due to the host cell-mediated DNA repair mechanism [69]. In addition, adenoviruses have another mechanism that ameliorates the DNA damage response, mediated by the E4 or F4 protein, which are involved in efficient adenovirus replication [70]. Therefore, adenoviruses were proposed as a virological index for water quality control due to their potential environmental stability [71].

Table 1. Occurrence of adenovirus in various water environments.

\begin{tabular}{|c|c|c|c|c|c|c|c|}
\hline Country & Water Source & $\begin{array}{c}\text { Frequency } \\
\text { (\% Positive) }\end{array}$ & Study Period & Concentration & $\begin{array}{l}\text { Species } \\
\text { (Serotype) }\end{array}$ & Assessment Tools & Reference \\
\hline \multirow{4}{*}{$\begin{array}{l}\text { Saudi } \\
\text { Arabia }\end{array}$} & Treated effluents & $44.44-61.11 \%$ & \multirow{4}{*}{$\begin{array}{c}\text { April } \\
\text { 2018-March } 2019\end{array}$} & \multirow{4}{*}{-} & \multirow{4}{*}{$\mathrm{F}(41)$} & \multirow{4}{*}{$\begin{array}{l}\text { PCR and direct } \\
\text { sequencing }\end{array}$} & \multirow{4}{*}[72]{} \\
\hline & Lakes & $75-77.78 \%$ & & & & & \\
\hline & $\begin{array}{c}\text { Wastewater } \\
\text { landfill }\end{array}$ & $83.33 \%$ & & & & & \\
\hline & Irrigation water & $52.78 \%$ & & & & & \\
\hline \multirow{3}{*}{ Egypt } & $\begin{array}{c}\text { Raw sewage } \\
\text { water }\end{array}$ & $84.4 \%$ & \multirow{2}{*}{$\begin{array}{l}\text { January- } \\
\text { December } \\
2017\end{array}$} & $\begin{array}{r}4.3 \times 10^{5}-8.7 \\
\times 10^{6} \mathrm{GC} / \mathrm{mL}\end{array}$ & \multirow[t]{2}{*}{-} & \multirow{2}{*}{$\begin{array}{l}\text { Conventional PCR and } \\
\text { Real-Time PCR }\end{array}$} & \multirow{2}{*}[73]{} \\
\hline & Treated effluents & $50 \%$ & & $\begin{array}{l}1.22 \times 10^{4}-3.7 \\
\times 10^{6} \mathrm{GC} / \mathrm{mL}\end{array}$ & & & \\
\hline & $\begin{array}{l}\text { Irrigation water } \\
\text { (Nile River) }\end{array}$ & $62.5 \%$ & $\begin{array}{l}\text { September- } \\
\text { December } \\
2017\end{array}$ & $1.5 \times 10^{7} \mathrm{GC} / \mathrm{L}^{\mathrm{a}}$ & - & $\begin{array}{l}\text { Real-Time PCR and } \\
\text { amplicon cloning }\end{array}$ & [74] \\
\hline \multirow{3}{*}{ Japan } & $\begin{array}{l}\text { Raw sewage } \\
\text { water }\end{array}$ & $100 \%$ & \multirow{3}{*}{$\begin{array}{l}\text { July 2003-June } \\
2004\end{array}$} & 320 PCR units $/ \mathrm{mL}^{\mathrm{a}}$ & \multirow{3}{*}{-} & \multirow{3}{*}{$\begin{array}{l}\text { TaqMan PCR and } \\
\text { quantification by the } \\
\text { MPN (Most probable } \\
\text { number method }\end{array}$} & \multirow{3}{*}{ [75] } \\
\hline & $\begin{array}{c}\text { Secondary } \\
\text { treated water ** }\end{array}$ & $99 \%$ & & $7 \mathrm{PCR}$ units $/ \mathrm{mL}^{\mathrm{a}}$ & & & \\
\hline & $\begin{array}{c}\text { Treated } \\
\text { effluents }\end{array}$ & $100 \%$ & & & & & \\
\hline \multirow[t]{2}{*}{ Tunisia } & $\begin{array}{c}\text { Raw sewage } \\
\text { water }\end{array}$ & $0.4 \%$ & \multirow{2}{*}{$\begin{array}{c}\text { January } \\
\text { 2003-April } 2007\end{array}$} & \multirow[t]{2}{*}{-} & $\mathrm{F}(41)$ & \multirow{2}{*}{$\begin{array}{l}\text { PCR and direct } \\
\text { sequencing }\end{array}$} & \multirow[t]{2}{*}{ [76] } \\
\hline & Treated effluents & $0 \%$ & & & - & & \\
\hline \multirow[t]{2}{*}{ Uruguay } & River & $18 \%$ & $\begin{array}{l}\text { June 2015-May } \\
2016\end{array}$ & $1.5 \times 10^{4} \mathrm{GC} / \mathrm{L}^{\mathrm{a}}$ & B (3) & $\begin{array}{c}\text { Real-Time PCR, cell } \\
\text { culture, ICC-qPCR, } \\
\text { nested PCR and } \\
\text { amplicon sequencing }\end{array}$ & [77] \\
\hline & $\begin{array}{l}\text { Underground } \\
\text { water }\end{array}$ & $0.7 \%$ & $\begin{array}{c}\text { November } \\
\text { 2013-September } \\
2014\end{array}$ & - & - & Nested PCR & [78] \\
\hline \multirow{2}{*}{ South Africa } & River & $30.56 \%$ & $\begin{array}{c}\text { August } \\
\text { 2010-July } 2011\end{array}$ & $8.49 \times 10^{4} \mathrm{GC} / \mathrm{L}^{\mathrm{b}}$ & $\begin{array}{l}C(1,2,5 \& \\
6) \text { and } F(41)\end{array}$ & $\begin{array}{l}\text { Real-Time PCR and } \\
\text { Multiplex PCR } \\
\text { (Serotype-specific) }\end{array}$ & [79] \\
\hline & Treated effluents & $64 \%$ & $\begin{array}{c}\text { September } \\
\text { 2012-August } \\
2013\end{array}$ & $2.37 \times 10^{5} \mathrm{GC} / \mathrm{L}^{\mathrm{b}}$ & $\begin{array}{l}C(2) \text { and } F \\
(41)\end{array}$ & $\begin{array}{l}\text { Real-Time PCR and } \\
\text { serotype-specific PCR }\end{array}$ & [80] \\
\hline Pakistan & Tap water & $20 \%$ & - & - & - & PCR & [81] \\
\hline \multirow{8}{*}{ USA } & $\begin{array}{l}\text { Raw sewage } \\
\text { water }\end{array}$ & $100 \%$ & $\begin{array}{c}\text { August } \\
\text { 2005-August } \\
\text { 2006 }\end{array}$ & $1.15 \times 10^{6}$ viruses $/ \mathrm{L}$ & $\begin{array}{l}\text { F (41) and } \\
\quad \text { A (12) }\end{array}$ & \multirow{6}{*}{$\begin{array}{l}\text { Real-Time PCR, } \\
\text { Molecular cloning } \\
\text { and sequencing }\end{array}$} & \multirow{6}{*}{ [67] } \\
\hline & $\begin{array}{c}\text { Combined sewer } \\
\text { overflows }\end{array}$ & $100 \%$ & $\begin{array}{l}\text { February-June } \\
2008\end{array}$ & $5.35 \times 10^{5}$ viruses $/ L$ & - & & \\
\hline & $\begin{array}{l}\text { Primary treated } \\
\text { water }\end{array}$ & - & \multirow{3}{*}{$\begin{array}{l}\text { August } \\
\text { 2005-August } \\
2006\end{array}$} & $1.12 \times 10^{6}$ viruses $/ \mathrm{L}$ & $\begin{array}{l}\text { F (41) and } \\
\quad \text { A (12) }\end{array}$ & & \\
\hline & $\begin{array}{l}\text { Secondary } \\
\text { treated water }\end{array}$ & - & & $2 \times 10^{4}$ viruses $/ \mathrm{L}$ & - & & \\
\hline & $\begin{array}{l}\text { Tertiary treated } \\
\text { water }\end{array}$ & - & & $8.3 \times 10^{4}$ viruses $/ \mathrm{L}$ & - & & \\
\hline & Surface water & $30 \%$ & $2006-2007$ & $7.76 \times 10^{3}$ viruses $/ \mathrm{L}$ & - & & \\
\hline & $\begin{array}{c}\text { Raw sewage } \\
\text { water }\end{array}$ & $100 \%$ & \multirow{2}{*}{ Fall 2007} & - & - & \multirow{2}{*}{$\begin{array}{l}\text { Nested PCR and } \\
\text { sequencing }\end{array}$} & \multirow{2}{*}{ [82] } \\
\hline & Treated effluents & $25 \%$ & & - & - & & \\
\hline
\end{tabular}


Table 1. Cont.

\begin{tabular}{|c|c|c|c|c|c|c|c|}
\hline Country & Water Source & $\begin{array}{l}\text { Frequency } \\
\text { (\% Positive) }\end{array}$ & Study Period & Concentration & $\begin{array}{l}\text { Species } \\
\text { (Serotype) }\end{array}$ & Assessment Tools & Reference \\
\hline Brazil & $\begin{array}{l}\text { Recreational } \\
\text { water (Lagoons } \\
\text { and beaches) }\end{array}$ & $93.1 \%^{c}$ & $\begin{array}{l}\text { March 2015-July } \\
2016\end{array}$ & $10^{9} \mathrm{GC} / \mathrm{L}^{\mathrm{b}}$ & $\mathrm{C}$ & $\begin{array}{l}\text { qPCR, ICC-qPCR, } \\
\text { Nested PCR and } \\
\text { sequencing }\end{array}$ & [83] \\
\hline \multirow{3}{*}{ Italy } & $\begin{array}{l}\text { Raw sewage } \\
\text { water }\end{array}$ & $96 \%$ & \multirow{2}{*}{$\begin{array}{c}\text { May-September } \\
2007\end{array}$} & $9.8 \times 10^{8} \mathrm{GC} / \mathrm{mL}$ & \multirow[t]{2}{*}{-} & \multirow[t]{2}{*}{ TaqMan real-time PCR } & \multirow[t]{2}{*}{ [84] } \\
\hline & Treated effluent & $76 \%$ & & $4.9 \times 10^{8} \mathrm{GC} / \mathrm{mL}$ & & & \\
\hline & $\begin{array}{c}\text { Raw sewage } \\
\text { water }\end{array}$ & $60 \%$ & $\begin{array}{l}\text { January- } \\
\text { December } \\
2013\end{array}$ & - & $\mathrm{F}(41)$ & $\begin{array}{l}\text { Nested PCR, Sanger } \\
\text { sequencing and Next } \\
\text { generation sequencing }\end{array}$ & [85] \\
\hline \multirow{3}{*}{ UK } & $\begin{array}{l}\text { Raw sewage } \\
\text { water }\end{array}$ & $90 \%$ & \multirow{3}{*}{$\begin{array}{c}\text { March } 2016 \text { and } \\
\text { August } \\
\text { 2016-August } \\
2017\end{array}$} & $6 \times 10^{5} \mathrm{GC} / \mathrm{L}^{\mathrm{b}}$ & \multirow{3}{*}{-} & \multirow{3}{*}{ SYBR Green qPCR } & \multirow{3}{*}{ [86] } \\
\hline & Treated effluent & $87 \%$ & & $10^{3} \mathrm{GC} / \mathrm{L}^{\mathrm{b}}$ & & & \\
\hline & Surface water & $88 \%$ & & $10^{5} \mathrm{GC} / \mathrm{L}^{\mathrm{b}}$ & & & \\
\hline Netherlands & $\begin{array}{l}\text { Drinking water } \\
\text { influents } * * * *\end{array}$ & $54 \%$ & 2012 & $2.5 \log _{10} \mathrm{GC} / \mathrm{L}^{\mathrm{a}}$ & $\mathrm{F}(40,41)$ & $\begin{array}{l}\text { Real-Time PCR } \\
\text { and mpnPCR }\end{array}$ & [87] \\
\hline China & $\begin{array}{l}\text { Recreational } \\
\text { water } \\
\text { (Swimming } \\
\text { pool) }\end{array}$ & $40 \%$ & May 2013 & - & $\mathrm{E}(4)$ & $\begin{array}{l}\text { Conventional PCR, } \\
\text { sequencing and cell } \\
\text { culture }\end{array}$ & [88] \\
\hline \multirow[b]{2}{*}{ Canada } & River upstream & $50 \%^{c}$ & \multirow{2}{*}{$\begin{array}{l}\text { June 2012-May } \\
2013\end{array}$} & $2.66 \log _{10} \mathrm{GE}^{*}$ copies $/ \mathrm{L}^{\mathrm{a}}$ & \multirow[b]{2}{*}{-} & \multirow[b]{2}{*}{ qPCR and ICC-qPCR } & \multirow[b]{2}{*}{ [89] } \\
\hline & $\begin{array}{c}\text { River } \\
\text { downstream }\end{array}$ & $92 \%^{c}$ & & 4.55 $\log _{10}$ GE copies/L & & & \\
\hline France & River & $100 \%$ & $\begin{array}{c}\text { January-June } \\
2016\end{array}$ & $3.6 \times 10^{3} \mathrm{GC} / \mathrm{L}^{\mathrm{a}}$ & $\mathrm{F}(41)$ & $\begin{array}{l}\text { MPN assay, ddPCR } \\
\text { (digital droplet PCR) } \\
\text { and ICC-qPCR }\end{array}$ & {$[90]$} \\
\hline \multirow{4}{*}{ Sweden } & $\begin{array}{l}\text { Raw sewage } \\
\text { water }\end{array}$ & \multirow{3}{*}{$100 \%$} & \multirow{3}{*}{$\begin{array}{c}\text { November- } \\
\text { December } 2015\end{array}$} & $9.07 \times 10^{4} \mathrm{GC} / \mathrm{mL}^{\mathrm{a}}$ & \multirow{3}{*}{$\mathrm{F}(41)$} & \multirow{3}{*}{$\begin{array}{l}\text { Nested PCR, Library } \\
\text { construction, } \\
\text { Ion-Torrent sequencing } \\
\text { and qPCR }\end{array}$} & \multirow{3}{*}{ [91] } \\
\hline & $\begin{array}{c}\text { Conventionally } \\
\text { treated water }\end{array}$ & & & $1.06 \times 10^{3} \mathrm{GC} / \mathrm{mL}^{\mathrm{a}}$ & & & \\
\hline & $\begin{array}{l}\text { Ozone treated } \\
\text { water }\end{array}$ & & & $8.25 \times 10^{3} \mathrm{GC} / \mathrm{mL}^{\mathrm{a}}$ & & & \\
\hline & $\begin{array}{c}\text { Raw sewage } \\
\text { water }\end{array}$ & $100 \%$ & $\begin{array}{c}\text { January-May } \\
2013\end{array}$ & $3.3 \times 10^{5}$ virus $/ \mathrm{L}^{\mathrm{b}}$ & - & $\begin{array}{l}\text { Real-Time PCR and } \\
\text { sequencing }\end{array}$ & [92] \\
\hline
\end{tabular}

${ }^{a}$ : mean adenovirus concentration, ${ }^{b}$ : maximum adenovirus concentration, ${ }^{c}$ : maximum detection limit (frequency), GC: genome copy. $*$ : genome equivalent, ${ }^{* *}$ : treated water before chlorination, ${ }^{* * *}$ : treated water after chlorination, ${ }^{* * * *}$ : last storage reservoir before treatment of drinking water, (-): not defined.

\subsection{Rotavirus}

Rotavirus is a double stranded RNA virus composed of 11 segments of a genome size of $\sim 18,550 \mathrm{bp}$ [93]. These segments differ in size from 667 to 3302 nucleotides (Figure 1). Viral capsid proteins (VP1, VP2, VP3, VP4, VP6, and VP7) are encoded by segments 1, 2, 3, 4, 6, and 9, respectively. The non-structural proteins (NSP1, NSP2, NSP3, NSP4, NSP5, and NSP6) are encoded by segments 5, 8, 7, 10, and 11, respectively. All segments have methylated cap structures at the $5^{\prime}$ end and a $3^{\prime}$ UGACC consensus sequence instead of the poly-A tail [94,95].

Rotaviruses are divided into seven serogroups (A-G) [96]. Rotavirus A is considered the principal cause of severe acute gastroenteritis throughout the world and predominantly results in severe acute diarrhea in children [97,98]. Moreover, the incidence of rotavirus diarrhea in developing countries accounts for 0.07 to 0.8 episodes per child annually [99] or at least one diarrheal episode by five years of age [9]. Rotaviruses showed a high prevalence in different water sources (Table 2 ). This could be owing to its broad tolerance to a wide range of temperatures $\left(-20^{\circ} \mathrm{C}\right.$ to $37^{\circ} \mathrm{C}$ ) and $\mathrm{pH}$ levels ( 3 to 11$)$ without a significant infectivity loss [100-104]. However, rotavirus A prevalence is influenced by seasonal variations, favoring lower temperatures in temperate countries [22,105], unlike the endemic manner of rotavirus in tropical countries [106]. In terms of rotavirus frequency, sewage influent of Brazil and, surprisingly, wastewater treatment plant (WWTP) effluents in China recorded the highest frequency, even higher than that reported in Chinese raw water, indicating a 
deficiency in the WWTP performance or probable sampling cross-contamination, as shown in Table 2. Moreover, rotaviruses were detected in rivers (18.75-83.33\%), raw sewage water $(21.2-100 \%)$, and treated effluents $(5-100 \%)$. Furthermore, rotaviruses were detected at significantly high concentrations, up to $1.16 \times 10^{7} \mathrm{GC} / \mathrm{L}$, in treated water influents and in treated effluents, at levels of $2.8 \times 10^{6} \mathrm{GC} / \mathrm{L}$, in Brazil and the USA, respectively, as displayed in Table 2 .

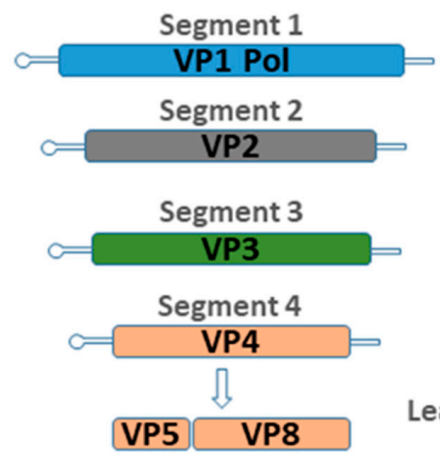

Structural Proteins
Segment 6 VP6

Segment 9

VP7 (1)

TVP7 (2)

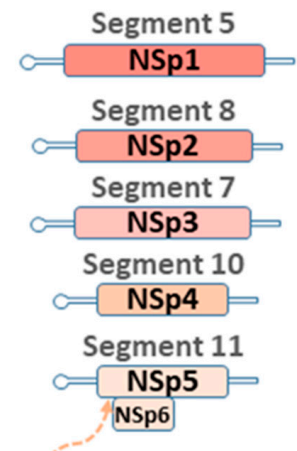

Leaky'scanning

\section{Non-structural Proteins}

Figure 1. Rotavirus genome structure.

The rotavirus outer capsid consists of two distinct neutralization antigens that are responsible for rotavirus attachment and entry, termed VP7 and VP4. They serve for virus classification, with each categorized into a G-genotype (16 genotype) and P-genotype (27 genotype thus far) [98]. Despite the wide spectrum of rotavirus genotypes resulting from G/P combinations, epidemiological studies showed that the most prevalent genotypes are $\mathrm{G} 1 \mathrm{P}(8), \mathrm{G} 3 \mathrm{P}(8), \mathrm{G} 4 \mathrm{P}(8), \mathrm{G} 9 \mathrm{P}(8)$, and G2P(4), which cause up to $90 \%$ of severe RVA infections worldwide $[107,108]$. Furthermore, there is no clear relationship between rotavirus genotypes and the severity of disease [109].

Table 2. Rotavirus frequency and dominant genotypes in different water sources.

\begin{tabular}{|c|c|c|c|c|c|c|c|}
\hline Country & Water Source & $\begin{array}{c}\text { Frequency } \\
(\% \text { Positive) }\end{array}$ & Study Period & Concentration & $\begin{array}{l}\text { Dominant } \\
\text { Genotypes }\end{array}$ & $\begin{array}{l}\text { Assessment } \\
\text { Tools }\end{array}$ & Reference \\
\hline \multirow{5}{*}{$\begin{array}{l}\text { Saudi } \\
\text { Arabia }\end{array}$} & Treated effluent & $5.56-13.89 \%$ & \multirow{4}{*}{$\begin{array}{l}\text { April 2018-March } \\
2019\end{array}$} & - & G2 & \multirow{4}{*}{$\begin{array}{l}\text { RT-PCR and } \\
\text { Sanger } \\
\text { sequencing }\end{array}$} & \multirow{4}{*}[22]{} \\
\hline & Lakes & $27.78-30.56 \%$ & & - & G2 & & \\
\hline & $\begin{array}{l}\text { Wastewater } \\
\text { landfill }\end{array}$ & $63.89 \%$ & & - & G2 & & \\
\hline & Irrigation water & 5.56 & & - & G2 & & \\
\hline & Dams & $13.33 \%$ & February-April 2017 & - & - & RT-PCR & [110] \\
\hline Japan & $\begin{array}{l}\text { Drinking water } \\
\text { effluent }\end{array}$ & $86 \%^{a}-95 \%{ }^{b}$ & $\begin{array}{c}\text { June 2017-August } \\
2018\end{array}$ & $5.5^{\mathrm{b}}-6.3^{\mathrm{a}} \log _{10} \mathrm{GC} / \mathrm{L}$ & - & $\begin{array}{c}\text { RT-PCR, } \\
\text { semi-nested PCR } \\
\text { and direct } \\
\text { sequencing }\end{array}$ & [111] \\
\hline \multirow{2}{*}{ Egypt } & Nile river & $18.75 \%$ & June 2016-May 2017 & - & $\begin{array}{l}\text { G1P(8) and } \\
\text { G1P(4) }\end{array}$ & $\begin{array}{c}\text { RT-PCR and } \\
\text { Multiplex } \\
\text { semi-nested PCR }\end{array}$ & [112] \\
\hline & $\begin{array}{l}\text { Irrigation water } \\
\text { (Nile river) }\end{array}$ & $50 \%$ & $\begin{array}{l}\text { September-December } \\
2017\end{array}$ & $2.7 \times 10^{5} \mathrm{GC} / \mathrm{L}^{\mathrm{d}}$ & - & $\begin{array}{c}\text { RT-PCR, } \\
\text { amplicon cloning } \\
\text { and qPCR }\end{array}$ & [74] \\
\hline \multirow[t]{2}{*}{ Tunisia } & $\begin{array}{c}\text { Raw sewage } \\
\text { water }\end{array}$ & $21.2 \%$ & \multirow{2}{*}{$\begin{array}{c}\text { January 2003-April } \\
2007\end{array}$} & \multirow[t]{2}{*}{-} & \multirow[t]{2}{*}{$\begin{array}{l}\mathrm{GxP}(8) \text { and } \\
\mathrm{GxP}(4)\end{array}$} & $\begin{array}{l}\text { RT-PCR and } \\
\text { direct }\end{array}$ & \multirow[t]{2}{*}{ [76] } \\
\hline & Treated effluent & $10.8 \%$ & & & & sequencing & \\
\hline \multirow{2}{*}{ Uruguay } & $\begin{array}{c}\text { River } \\
\text { watersheds }\end{array}$ & $41 \%^{c}$ & June 2015-May 2016 & $1.3 \times 10^{5} \mathrm{GC} / \mathrm{L}^{\mathrm{d}}$ & - & $\begin{array}{l}\text { RT-PCR and } \\
\text { Real-Time PCR }\end{array}$ & [105] \\
\hline & $\begin{array}{l}\text { Underground } \\
\text { water }\end{array}$ & $32 \%$ & $\begin{array}{c}\text { November } \\
\text { 2013-September } 2014\end{array}$ & $1.72 \times 10^{3} \mathrm{GC} / \mathrm{L}^{\mathrm{a}}$ & & $\begin{array}{l}\text { RT-PCR and } \\
\text { qPCR }\end{array}$ & [78] \\
\hline
\end{tabular}


Table 2. Cont.

\begin{tabular}{|c|c|c|c|c|c|c|c|}
\hline Country & Water Source & $\begin{array}{l}\text { Frequency } \\
\text { (\% Positive) }\end{array}$ & Study Period & Concentration & $\begin{array}{l}\text { Dominant } \\
\text { Genotypes }\end{array}$ & $\begin{array}{l}\text { Assessment } \\
\text { Tools }\end{array}$ & Reference \\
\hline $\begin{array}{l}\text { South } \\
\text { Africa }\end{array}$ & Treated effluents & $41.7 \% \mathrm{e}^{\mathrm{e}}$ & $\begin{array}{c}\text { September } \\
\text { 2012-August } 2013\end{array}$ & $5.2 \times 10^{3}-1.2 \times 10^{5} \mathrm{GC} / \mathrm{L}^{\mathrm{f}}$ & - & $\begin{array}{c}\text { RT-PCR and } \\
\text { Real-Time PCR }\end{array}$ & [113] \\
\hline \multirow[b]{3}{*}{ Pakistan } & Treated effluents & $5 \%$ & \multirow{2}{*}{ February-July 2014} & \multirow[t]{2}{*}{-} & \multirow[t]{2}{*}{-} & \multirow{2}{*}{$\begin{array}{l}\text { Enzyme-linked } \\
\text { immunosorbent } \\
\text { assay (ELISA) }\end{array}$} & \multirow{2}{*}{ [114] } \\
\hline & Drinking water & $5 \%$ & & & & & \\
\hline & $\begin{array}{c}\text { Surface water } \\
\text { (River and dam } \\
\text { water) }\end{array}$ & $23 \%$ & $\begin{array}{c}\text { November } \\
\text { 2014-February } 2015 \\
\text { and April 2015-July } \\
2015\end{array}$ & - & G3 and G9 & $\begin{array}{c}\text { RT-PCR, } \\
\text { Nested-PCR and } \\
\text { sequencing }\end{array}$ & [115] \\
\hline USA & Treated effluents & $83 \%$ & $\begin{array}{l}\text { August 2011-July } \\
2012\end{array}$ & $2.8 \times 10^{6} \mathrm{GC} / \mathrm{L}^{\mathrm{f}}$ & - & $\begin{array}{l}\text { RT-PCR and } \\
\text { qPCR }\end{array}$ & [116] \\
\hline \multirow[t]{2}{*}{ Brazil } & $\begin{array}{c}\text { Raw sewage } \\
\text { water }\end{array}$ & $100 \%$ & \multirow{2}{*}{$\begin{array}{l}\text { August 2009-July } \\
2010\end{array}$} & $\begin{array}{c}2.40 \times 10^{5}-1.16 \\
\times 10^{7} \mathrm{GC} / \mathrm{L}^{\mathrm{e}} \\
\end{array}$ & \multirow{2}{*}{$\begin{array}{l}\text { G2P(4) and } \\
\text { G2P(6) }\end{array}$} & \multirow{2}{*}{$\begin{array}{l}\text { RT-PCR, qPCR, } \\
\text { Nested PCR and } \\
\text { amplicon } \\
\text { sequencing }\end{array}$} & \multirow[t]{2}{*}[117]{} \\
\hline & Treated effluents & $71 \%$ & & $\begin{array}{c}1.35 \times 10^{3}-1.64 \\
\times 10^{5} \mathrm{GC} / \mathrm{L}^{\mathrm{e}}\end{array}$ & & & \\
\hline Italy & $\begin{array}{l}\text { Raw sewage } \\
\text { water }\end{array}$ & $60.4 \%$ & 2010-2011 & - & $\begin{array}{l}\text { G1P(8) and } \\
\text { G2P(4) }\end{array}$ & $\begin{array}{l}\text { RT-PCR, Nested } \\
\text { PCR and } \\
\text { amplicon } \\
\text { sequencing }\end{array}$ & [118] \\
\hline Netherlan & Is Drinking water & $48 \%$ & 1999-2002 & $2.2 \times 10^{3} \mathrm{PDU} /$ liter $^{\mathrm{f}}$ & - & $\begin{array}{l}\text { RT-PCR, and } \\
\text { molecular } \\
\text { cloning }\end{array}$ & [119] \\
\hline \multirow{4}{*}{ China } & $\begin{array}{l}\text { Surface water } \\
\text { (Rivers) }\end{array}$ & $75-83.33 \%$ & \multirow{4}{*}{$\begin{array}{c}\text { September } \\
\text { 2014-August } 2015\end{array}$} & \multirow{4}{*}{-} & \multirow{4}{*}{-} & \multirow{4}{*}{$\begin{array}{l}\text { (RT-)qPCR and } \\
\text { sequencing }\end{array}$} & \multirow{4}{*}{ [120] } \\
\hline & Treated effluent & $100 \%$ & & & & & \\
\hline & $\begin{array}{l}\text { Raw sewage } \\
\text { water }\end{array}$ & $91.67 \%$ & & & & & \\
\hline & Tap water & $91.67 \%$ & & & & & \\
\hline Canada & $\begin{array}{l}\text { Surface water } \\
\text { (Rivers) }\end{array}$ & $37 \%{ }^{g}-75 \%$ h & June 2012-May 2013 & $4.5 \log _{10} \mathrm{GE}^{*}$ copies $/ \mathrm{L}^{\mathrm{f}}$ & G1 & $\begin{array}{l}\text { (RT-)qPCR, cell } \\
\text { culture and } \\
\text { ICC-qPCR } \\
\text { (integrated cell } \\
\text { culture with } \\
\text { qPCR) and } \\
\text { sequencing }\end{array}$ & [89] \\
\hline
\end{tabular}

${ }^{\mathrm{a}}$ : in epidemic season, ${ }^{\mathrm{b}}$ : in non-epidemic season, ${ }^{\mathrm{c}}$ : mean detection frequency, ${ }^{\mathrm{d}}$ : mean rotavirus concentration, ${ }^{\mathrm{e}}:$ maximum detection frequency, ${ }^{\mathrm{f}}$ : maximum rotavirus concentrations, $\mathrm{g}$ : in upstream sites, ${ }^{\mathrm{h}}$ : in downstream sites. *: genome equivalent, GC: genome copy, (-): not defined.

\subsection{Norovirus}

Norovirus (NoV) is a member of the family Caliciviridae, with a polyadenylated, positive-sense, single-stranded RNA genome sized $\sim 7.5 \mathrm{~kb}$. The $\geq 40$ genotypes are classified into seven genogroups (GI-GVII) [121,122]. NoV infection is considered the most prevalent non-bacterial mediated gastroenteritis, causing $\sim 20 \%$ of entire gastroenteritis cases worldwide [123], particularly in five years old and younger children [124]. NoV causes $\sim 685$ million diarrheal episodes [125] and 200,000 deaths per year [126]. Norovirus infection symptoms occurs after an average incubation period of 24 to $48 \mathrm{~h}$, typically involving vomiting, nausea diarrhea, dehydration, fever, and abdominal cramps [127].

The NoV genome organization involves three or four open reading frames (ORFs). The first ORF (ORF1) encodes for six non-structural (NS) proteins, including NS1/2 (NTerm), NS3 (NTPase), NS4 (3A-like), NS5 (VPg), NS6 (Protease), and NS7 (RNA-dependent RNA polymerase; RdRp), which are responsible for viral replication. However, the other two ORFs (ORF2 and ORF3) encode two structural viral proteins (VP), comprising of VP1 (major) and VP2 (minor capsid protein), respectively (Figure 2) [128]. Norovirus typing was conventionally based upon sequence diversity within the capsid protein sequence. Noroviruses could be grouped into ten genogroups (GI-GX). Generally, genogroups vary by around $40-60 \%$ of their amino acid sequence: less sequence variance (20-40\%) in the case of genotypes [129]. Moreover, genotypes can be sub-divided into variants [130]. Currently, 
the RdRp-encoding region is used for dual genotyping of norovirus based on genotype and P type; GI.1[P1], for example [129].

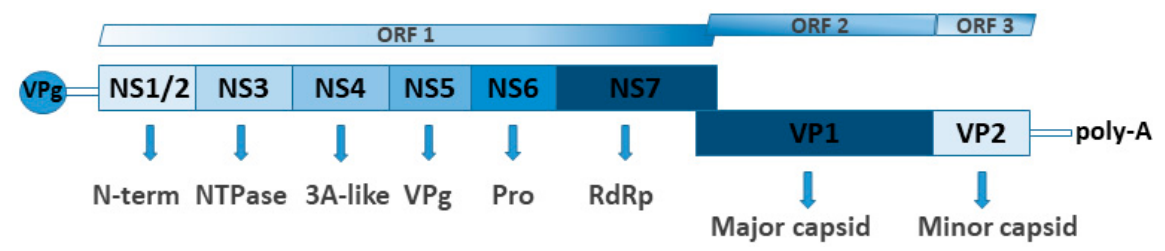

Figure 2. Genome organization of norovirus.

Humans can be infected by more than 30 genotypes of noroviruses. Furthermore, noroviruses show significant host specificity, which is at variance with evidence suggesting inter-species transmission [131-133], in addition to the detection of viral RNA from human strains in different animals [133-137]. Initially, human strains of viral RNA displayed a potentially limited replication capacity in animals [138-140]. Moreover, GI and GII viruses are mainly responsible for human infections [130], GIII viruses are associated with ovine and bovine species [141,142], GV viruses are specific for murine species (mice and rats) [143,144], and GIV, GVI, and GVII viruses are associated with various carnivorous species, notably felines and canines [145-147]. Furthermore, GVIII and GIX, which are novel genogroups, were detected in humans, while GX was described in bats [129]. However, there are some exceptions to the species specificity of GII and GIV genogroups. For instance, GII.11, GII.18, and GII.19 were described in pigs [148], but not detected in humans, while GIV.1 and GIV.NA1 were associated with humans only, but not found in canines or felines [149].

Analyses of outbreaks identified GII noroviruses as the most frequently circulating strains causing gastrointestinal infections worldwide [150]. Over the past 20 years, GII.4 became the predominant genotype, resulting in $70-80 \%$ of NoV outbreaks in various countries [151]. This genotype is potentially evolving, yielding new pandemic variants, including Grimsby 1995 (or US95_96), Farmington Hills 2002, Hunter 2004, Den Haag 2006b, New Orleans 2009, and Sydney 2012 [152,153]. This strain diversity arises from both genome recombinations and mutational events, since significantly higher non-synonymous changes were observed in comparison with other NoVs, supporting the antigenic drift proposal, although occurring at a higher rate [154,155].

Noroviruses are mainly transmitted via the fecal-oral route, through the ingestion of contaminated food or water, or by oral contact with a contaminated fomite existing in the surrounding environment [156]. Moreover, high rates of secondary infection arise via airborne transmission, although the fomite route is more dominant $[157,158]$. The biological characteristics of norovirus were extensively studied through human feeding study volunteers [159-162]. Norovirus inocula as low as 10 viral particles were sufficient to initiate infection $[161,163]$. This potentially low count-mediated infection is regarded as highly critical when discussing norovirus survival. Strikingly, norovirus was depicted to be of stable infectivity under freezing and thawing conditions [164], although a more recent study showed altered stability upon exposure to three cycles of freezing and thawing [165]. Moreover, it shows a high capacity of survival in a wide spectrum of water bodies (Table 3), as well as thermal resistance, despite being exposure time-restricted to up to $21 \mathrm{~min}$ decimal reduction time (time required at a given temperature to perform a log reduction) in the temperature range of $50-72{ }^{\circ} \mathrm{C}[166,167]$. Furthermore, longer exposure time was detected at $50-60{ }^{\circ} \mathrm{C}$, despite irreversible capsid disruption at $>65^{\circ} \mathrm{C}$ and loss of binding capacity at $72{ }^{\circ} \mathrm{C}$ [168]. This high survival capacity can be demonstrated in a norovirus outbreak that occurred in a long-term care facility in which fomite-mediated survival of norovirus resulted in a continuous infection for 14 days following the initial peak of illness [169]. Notably, noroviruses were detected in rivers $(0-100 \%)$, recreational water $(25-50 \%)$, raw sewage water $(2.8-100 \%)$, and treated effluents $(1.6-100 \%)$, as displayed in Table 3. Furthermore, noroviruses were detected at the highest concentrations, of $7.9 \log _{10} \mathrm{GC} / \mathrm{L}$, in combined wastewater in the USA (Table 3). 
Table 3. Norovirus occurrence in various water bodies.

\begin{tabular}{|c|c|c|c|c|c|c|c|}
\hline Country & Water Source & $\begin{array}{c}\text { Frequency } \\
(\% \text { Positive) }\end{array}$ & Study Period & Concentration & Genogroups (Genotype) & Assessment Tools & Reference \\
\hline Saudi Arabia & Raw sewage water & $19 \%$ & January 2009-February 2010 & - & - & One step RT-PCR & [170] \\
\hline \multirow{5}{*}{ Egypt } & Raw sewage water & $25 \%$ & \multirow{2}{*}{ April 2017-March 2018} & \multirow{2}{*}{-} & \multirow{2}{*}{$\mathrm{GI}^{\ddagger}$ and GII } & \multirow{2}{*}{ Semi-nested RT-PCR } & \multirow{2}{*}{ [171] } \\
\hline & River & $0 \% *-16.6 \% * *$ & & & & & \\
\hline & Irrigation water & $31.25 \%$ & September-December 2017 & $3.5 \times 10^{3} \mathrm{GC} / \mathrm{L}^{\mathrm{a}}$ & GI & $\begin{array}{l}\text { One step RT-PCR, Amplicon cloning and } \\
\text { Real-Time PCR }\end{array}$ & [74] \\
\hline & Urban sewage water & $33.3 \%$ & \multirow{2}{*}{ October 2017-September 2018} & \multirow{2}{*}{-} & $\mathrm{GI}^{\ddagger}$ and GII & \multirow{2}{*}{ RT-PCR and Semi- nested RT-PCR } & \multirow{2}{*}{ [172] } \\
\hline & Treated effluents & $25 \%$ & & & GI and GII & & \\
\hline \multirow[t]{3}{*}{ Japan } & Raw sewage water & $50 \%$ & \multirow{2}{*}{ March 2005-February 2006} & $6.9 \times 10^{4} \mathrm{GC} / \mathrm{L}^{\mathrm{b}}$ & \multirow{3}{*}{ GIV } & \multirow{3}{*}{ RT-PCR and TaqMan-based real-time PCR } & \multirow{3}{*}{ [174] } \\
\hline & Treated effluents & $25 \%$ & & $4.8 \times 10^{3} \mathrm{GC} / \mathrm{L}^{\mathrm{b}}$ & & & \\
\hline & River water & $31 \%$ & April 2003-March 2004 & $1.5 \times 10^{4} \mathrm{GC} / \mathrm{L}^{\mathrm{b}}$ & & & \\
\hline \multirow{2}{*}{ Tunisia } & Raw sewage water & $2.8 \%$ & \multirow{2}{*}{ January 2003-April 2007} & \multirow{2}{*}{-} & \multirow{2}{*}{$\begin{array}{l}\mathrm{GI}(2), \mathrm{GI}(5), \mathrm{GI}(9) \text { and } \\
\mathrm{GII}(4)^{\ddagger}\end{array}$} & \multirow{2}{*}{$\begin{array}{l}\text { RT-PCR, Second-round typing PCR and } \\
\text { amplicon sequencing }\end{array}$} & \multirow{2}{*}{ [76] } \\
\hline & Treated effluents & $1.6 \%$ & & & & & \\
\hline \multirow{2}{*}{ South Africa } & Raw sewage water & $72.2 \%$ & \multirow{2}{*}{ April 2015-March 2016} & $6.0 \times 10^{5} \mathrm{GC} / \mathrm{L}^{\mathrm{b}}$ & \multirow{2}{*}{$\begin{array}{c}\left.\mathrm{GI}(4){ }^{\ddagger}, \mathrm{GII}(2)\right)^{\ddagger} \text { and } \\
\mathrm{GII}(17)^{\ddagger}\end{array}$} & \multirow{2}{*}{$\begin{array}{l}\text { Real-time reverse transcription-PCR, } \\
\text { semi-nested RT-PCR, conventional PCR, } \\
\text { amplicon cloning and clone sequencing }\end{array}$} & \multirow[t]{2}{*}{ [175] } \\
\hline & Treated effluents & $83.3 \%$ & & $6.8 \times 10^{6} \mathrm{GC} / \mathrm{L}^{\mathrm{b}}$ & & & \\
\hline India & Tap water ư & $16.67 \%$ & $\begin{array}{l}\text { June-July } 2015 \text { and } \\
\text { April-October } 2017\end{array}$ & $\begin{array}{c}1.9 \times 10^{4} \mathrm{GC} / \mathrm{L}^{+, \mathrm{b}} \text { and } \\
8.0 \times 10^{4} \mathrm{GC} / \mathrm{L}^{¥}, \mathrm{~b}\end{array}$ & GI and GII & $\begin{array}{l}\text { RT-PCR, ddPCR (singleplex and multiplex } \\
\text { probe-based assays) }\end{array}$ & [177] \\
\hline \multirow[b]{2}{*}{ USA } & Untreated graywater & $6 \%$ & \multirow[b]{2}{*}{ December-April, June, July } & $2.5 \log _{10} \mathrm{GC} / \mathrm{L}$ & GII & \multirow[b]{2}{*}{ two-step RT-qPCR and duplexed RT-ddPCR } & \multirow[b]{2}{*}{ [178] } \\
\hline & Combined wastewater & $39 \%^{+}-96 \%{ }^{¥}$ & & $\begin{array}{c}4.0 \log _{10} \mathrm{GC} / \mathrm{L}^{+, \mathrm{b}} \text { and } \\
7.9 \log _{10} \mathrm{GC} / \mathrm{L}^{¥, \mathrm{~b}}\end{array}$ & GI and GII ${ }^{\ddagger}$ & & \\
\hline Mexico & $\begin{array}{l}\text { Recreational water } \\
\text { (karst aquifer) }\end{array}$ & $40 \%{ }^{*}-50 \%{ }^{+}$ & - & $\begin{array}{c}1.6 \times 103 \mathrm{GC} / \mathrm{L}^{+, \mathrm{b}} \text { and } \\
2.9 \times 10^{2} \mathrm{GC} / \mathrm{L}^{¥, \mathrm{~b}}\end{array}$ & $\mathrm{GI}(2)$ and $\mathrm{GII}(17)^{\ddagger}$ & $\begin{array}{l}\text { RT-qPCR, Nested PCR, amplicon cloning, and } \\
\text { Sanger sequencing }\end{array}$ & [179] \\
\hline \multirow{2}{*}{ Norway } & Raw sewage water & $100 \%$ & \multirow{2}{*}{ February 2008-February 2009} & $\begin{array}{l}6.1 \log _{10} \mathrm{GC} / \mathrm{L}^{+, \mathrm{b}} \text { and } \\
\quad 6.3 \log _{10} \mathrm{GC} / \mathrm{L}^{¥, \mathrm{~b}}\end{array}$ & \multirow{2}{*}{ GI and GII } & \multirow{2}{*}{$\begin{array}{l}\text { RT-PCR, two genogroup-specific monoplex PCR } \\
\text { and direct sequencing }\end{array}$} & $5180]$ \\
\hline & Treated effluents & $95 \%^{\mathrm{c}}$ & & $\begin{array}{c}5.65 \log _{10} \mathrm{GC} / \mathrm{L}^{+, \mathrm{b}} \\
5.75 \mathrm{GC} / \mathrm{L}^{¥, \mathrm{~b}}\end{array}$ & & & {$[100]$} \\
\hline
\end{tabular}


Table 3. Cont

\begin{tabular}{|c|c|c|c|c|c|c|c|}
\hline Country & Water Source & $\begin{array}{c}\text { Frequency } \\
(\% \text { Positive) }\end{array}$ & Study Period & Concentration & Genogroups (Genotype) & Assessment Tools & Reference \\
\hline \multirow{3}{*}{ Brazil } & Raw sewage water & $38.5 \%^{\dagger}-96.1 \%{ }^{¥}$ & \multirow{3}{*}{ May 2013-May 2014} & \multirow{3}{*}{$\begin{array}{l}6.2 \log _{10} \mathrm{GC} / \mathrm{L}^{+, \mathrm{b}_{-}} \\
7.3 \log _{10} \mathrm{GC} / \mathrm{L}^{¥, \mathrm{~b}}\end{array}$} & \multirow{3}{*}{$\begin{array}{l}\text { GI, GII.4 }{ }^{\ddagger}, \text { GII.17, GII.5, } \\
\text { GII.2, GII.3 and GII.1 }\end{array}$} & \multirow{3}{*}{ RT-PCR, qPCR and Sanger sequencing } & \multirow{3}{*}{ [181] } \\
\hline & Primary effluent & $40.4 \%^{+}-96.1 \%^{*}$ & & & & & \\
\hline & Final effluent & $1.9 \%^{\dagger}-5.8 \%{ }^{¥}$ & & & & & \\
\hline \multirow{2}{*}{ Italy } & $\begin{array}{c}\text { Treated urban } \\
\text { wastewater stream }\end{array}$ & $30 \%$ & \multirow{2}{*}{ May-September 2018} & $13 \mathrm{GC} / \mathrm{L}^{\mathrm{b}}$ & \multirow{2}{*}{$\mathrm{GI}(4)$ and $\mathrm{GII}{ }^{\ddagger}$} & \multirow{2}{*}{$\begin{array}{l}\text { Real-time RT-qPCR and Qualitative } \\
\text { nested (RT)-PCR }\end{array}$} & \multirow{2}{*}{ [182] } \\
\hline & $\begin{array}{l}\text { Recreational (bathing) } \\
\text { water }\end{array}$ & $25 \%$ & & $3.2 \mathrm{GC} / \mathrm{L}^{\mathrm{b}}$ & & & \\
\hline \multirow{3}{*}{ Netherlands } & Raw sewage water & \multirow{2}{*}{$100 \%$} & \multirow{3}{*}{ November 1998-April 1999} & $8.5 \times 10^{6} \mathrm{PDU}^{\S} /$ liter $^{\mathrm{b}}$ & \multirow{2}{*}{$\begin{array}{l}\mathrm{GI}(2), \mathrm{GI}(1), \mathrm{GI}(2), \mathrm{GII}(3) \\
\mathrm{GII}(4)^{\ddagger} \stackrel{\text { and }}{\mathrm{GII}}(7)\end{array}$} & \multirow{3}{*}{$\begin{array}{l}\text { RT-PCR, Southern blotting, amplicon cloning } \\
\text { and sequencing }\end{array}$} & \multirow{3}{*}{ [183] } \\
\hline & Treated effluents & & & $2.7 \times 10^{5} \mathrm{PDU} /$ liter $^{\mathrm{b}}$ & & & \\
\hline & Surface water (Rivers) & $100 \%$ & & $4.6 \times 10^{4} \mathrm{PDU} /$ liter $^{\mathrm{b}}$ & $\begin{array}{l}\mathrm{GI}(2), \mathrm{GI}(4), \mathrm{GII}(3), \mathrm{GII}(4)^{\ddagger} \\
\text { and } \mathrm{GII}(7)\end{array}$ & & \\
\hline \multirow[b]{2}{*}{ China } & Drinking (barreled) water & $45.5 \%^{\mathrm{d}}$ & February 2014 & - & GII & RT-PCR & [184] \\
\hline & $\begin{array}{l}\text { Tap water (Secondary } \\
\text { Water Supply System) }\end{array}$ & $50 \%$ & May 2017 & - & GII(17) & RT-PCR, Targeted gene (RdRP) sequencing & [185] \\
\hline \multirow{2}{*}{ Canada } & River upstream & $50 \%{ }^{\mathrm{d}}$ & \multirow{2}{*}{ June 2012-May 2013} & $3.24 \log _{10}$ GE copies/L & \multirow{2}{*}{-} & \multirow{2}{*}{ Two-step RT-qPCR } & \multirow{2}{*}{ [89] } \\
\hline & River downstream & $75 \%^{d}$ & & $4.43 \log _{10}$ GE copies/L & & & \\
\hline \multirow{4}{*}{ Sweden } & Raw sewage water & $100 \%$ & \multirow{3}{*}{ November-December 2015} & $\begin{array}{l}4.3 \times 10^{4} \mathrm{GC} / \mathrm{mL}^{\mathrm{b},+}{ }_{-} \\
6.5 \times 10^{4} \mathrm{GC} / \mathrm{mL}^{\mathrm{b}, ¥}\end{array}$ & GI and GII & \multirow{3}{*}{$\begin{array}{l}\text { RT-PCR, nested PCR, library construction, } \\
\text { Ion-torrent sequencing and qPCR }\end{array}$} & \multirow{3}{*}{ [91] } \\
\hline & $\begin{array}{l}\text { Conventionally treated } \\
\text { effluents }\end{array}$ & & & $3.9 \times 10^{2} \mathrm{GC} / \mathrm{mL}^{\mathrm{b}}$ & GII & & \\
\hline & Ozone treated effluents & $33.3 \%$ & & $61 \mathrm{GC} / \mathrm{mL}$ & GII & & \\
\hline & Raw sewage water & $100 \%$ & January-May 2013 & $\begin{array}{c}3.5 \times 10^{3} \text { virus } \\
\text { particle } / \mathrm{L}^{\mathrm{b}, \mathrm{t}}-3.2 \times 10^{5} \text { virus } \\
\text { particle } / \mathrm{L}^{\mathrm{b}, \mathrm{F}}\end{array}$ & GI and GII & RT-PCR and qPCR & [92] \\
\hline
\end{tabular}

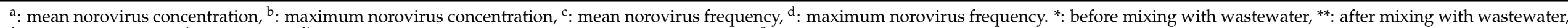

$\ddagger$ : dominant genotype ${ }^{\dagger}:$ : genogroup I, $\stackrel{¥}{*}$ : genogroup II, ${ }^{\circ}$ : dead-end ultrafiltration (DEUF) samples,, : PCR-detectable units (PDU), GC: genome copy, (-): not defined. 


\subsection{Hepatitis A Virus (HAV)}

The hepatitis A virus belongs to the family Picornaviridae, genus Hepatovirus, and is a non-enveloped positive-sense, single-stranded RNA virus of $\sim 7.5 \mathrm{~kb}$ genome packaged within a 27-32 nm icosahedral capsid [186]. The HAV genome is composed of a single ORF, whose translation occurs by means of a cap-independent mechanism, making the use of the internal ribosome entry site (IRES) located upstream of the genome producing a polyprotein composed of $\sim 2230$ amino acids [187]. This polyprotein consists of three distinct domains (P1, P2, and P3), which are further processed into 10 mature proteins by the virus-encoded proteinase, $3 C^{\text {pro }}[186,188]$. $\mathrm{P} 1$ encodes the four major capsid proteins VP1-VP4. The nonstructural viral proteins are comprised of the polyprotein domains P2 and P3, and also "processed" by 3C ${ }^{\text {pro }}$ [189]. HAV displays a high degree of conservation of the antigenic determinants—notably in amino acid sequences of viral capsids-now expanded to include the recently identified HAV-like viruses [190,191]. This could have resulted from negative selection pressures imposed upon any naturally-occurring mutants, producing the observed consensus conservation [192]. Despite the high conservation of HAV, a degree of genomic sequence divergence exists defining the various HAV genotypes and the identity of sub-genogroups $[192,193]$. Consequently, HAV genotyping is dependent on different regions of its genome used to recognize HAV variants, including the VP1 entire region, notably the VP1 amino terminus, the $168 \mathrm{bp}$ VP1-2A junction, the VP1-2B region, the VP3-2B region, the VP3 carboxy-terminus, and the $5^{\prime}$ untranslated region [194,195]. Based on VP1-2A junction region variability (of $~ 15 \%$ ), seven genotypes of HAV were primarily defined. However, according to the $23.7 \%$ variation denoted by the entire VP1 sequence analyses, six HAV genotypes (I-VI) are currently defined, encompassing genotypes $1 \mathrm{~A}$, 1B, II, III, IV, V, and VI [196,197]. Genotypes I, II, and III infect humans and are divided into A and B subtypes, however genotypes IV to VI are called simian HAV (SHAV) since they infect non-human primates [196,198]. Amongst human HAV genotypes, subtype IA was found to be the most frequently circulating subtype worldwide [199]. Interestingly, individuals cannot be re-infected by HAV since the presence of a single HAV serotype results in the neutralization of IgG production against $\mathrm{HAV}$, elicited upon vaccination or even natural infection [200].

On the other hand, HAV infections can range in associated severity from asymptomatic to fulminant hepatitis-mediated deaths [201,202]. However, HAV commonly causes selflimiting infections that do not lead to chronic liver disease [200,203]. Moreover, clinical manifestations can increase with age, manifested by jaundice, and unusually high serum aminotransferase levels as the common symptoms, which are exhibited by over $70 \%$ of infected adult patients [201,204]. Furthermore, the incubation period of HAV lasts for $\sim 15-50$ days, with an average of 28 days [205]. A wide range of symptoms occur upon $\mathrm{HAV}$ infection, including gastroenteritis, malaise, fever, nausea, anorexia, jaundice, dark urine (genitourinary symptom), and abdominal discomfort [206]. Fulminant hepatitis is considered as a rare complication associated with HAV infections that occurs in less than $1 \%$ of infected patients, wherein the highest incidence rates occur in young children and the elderly with reported underlying liver illnesses [205,207]. Nucleotide substitutions at the $5^{\prime}$ UTR, P2, and P3 regions of the HAV genome were found to be associated with this fulminant disease $[207,208]$.

HAV is mainly transmitted via the fecal-oral route, as well as through personal contact and exposure to contaminated water/food supplies, whereas transmission routes of the other typically hepatitis-causing viruses, in particular hepatitis B and C, involve contaminated blood or other body fluids via injection, intimate contact, or perinatal period vertical transmission [209]. Remarkably, waterborne HAV outbreaks are uncommon in developed countries owing to proper sanitation procedures, as well as water supply facilities [210]. On the other hand, HAV was found to be of high stability and abundance in the surrounding water environments (Table 4) for long periods, whenever associated with organic matter $[207,211]$. For instance, HAV was detected to be infectious after more than one year of storage at $4{ }^{\circ} \mathrm{C}$ in bottled water, with $<1$ log reduction owing to 
concentrations of the added proteins [211,212]. Moreover, HAV shows significant resistance to surprisingly low $\mathrm{pH}$, since it was reported that infectivity remains after treatment at $\mathrm{pH} 1$ for up to $5 \mathrm{~h}$ at room temperature, and for $1.5 \mathrm{~h}$ at $38^{\circ} \mathrm{C}$ and a $\mathrm{pH} 3$ for up to 21 days at $4^{\circ} \mathrm{C}[213,214]$. The environmental stability of HAV, displayed by its low $\mathrm{pH}$ as well as heat resistance $\left(60^{\circ} \mathrm{C}\right.$ for $\left.1 \mathrm{~h}\right)$, could be due to the inherent molecular stability of the HAV capsid, concurrent with its particular codon usage, along with the unique folding pattern of the VP2 protein $[190,215,216]$. Moreover, HAV was detected in rivers $(1.19-76 \%)$, recreational water $(0-13.95 \%)$, raw sewage water $(1.75-100 \%)$, and treated effluents (0-64.7\%), as shown in Table 2. In addition, HAV was detected at potentially high concentrations, up to $6.0 \times 10^{6} \mathrm{GC} / \mathrm{L}$, in treated effluents and, at $2.7 \times 10^{6} \mathrm{GC} / \mathrm{L}$, in raw sewage water in Tunisia.

Ingestion of HAV-contaminated food accounts for $2-7 \%$ of all HAV-mediated outbreaks worldwide [217]. Epidemiological investigations provide a potential solution since they have succeeded previously in identifying the source of contamination. For example, a large and persistent food-borne mediated multi-state HAV outbreak occurred in Europe, from 2013 to 2014, which was determined to be due to the ingestion of HAV-contaminated frozen berries. This led to over 1589 cases and 2 deaths [218,219]. Moreover, bivalve molluscan shellfish was reported to have significant HAV levels, showing various prevalence spatially and temporally [220-222]. For example, the prevalence of HAV severely declined over the years from $40 \%$ to $<8 \%$, according to the 20 year-systematic survey conducted on bivalve molluscan shellfish from three estuaries in Spain [220], accompanied by a reduction in HAV cases. However, the reduction in cases could be due to the increasing availability of the HA vaccine, alongside increased surveillance that can rapidly identify contaminated food $[217,223]$.

\subsection{Astrovirus}

Human astroviruses (HAstV) are members of the family Astroviridae, genus Mamastrovirus. They are non-enveloped icosahedral viruses, with a linear positive sense, single-stranded, RNA genome ranging from 6.4-7.9 kb [238]. The genome consists of three ORFs, comprising of ORF1a, ORF1b, and ORF2, which are flanked by $5^{\prime}$ and $3^{\prime}$ UTRs (85 and 83 nts, respectively) and a $3^{\prime}$ poly-A tail (Figure 3). ORF1a and ORF1b encode two functional polyproteins (nsp1a and nsp1ab), encompassing a serine protease and a RNA-dependent RNA-polymerase (RdRp). ORF2 encodes the capsid proteins precursor, translated from a sub-genomic RNA (sgRNA), and comprises of two principal domains: the highly conserved amino (N)-terminus and the hypervariable carboxy (C)terminus $[239,240]$. In addition, the viral genome encodes genomic linked protein (VPg) that plays a major role in viral infectivity (notably the TEEEY-like tract), the replication of the virus genome, and protein synthesis [241,242].

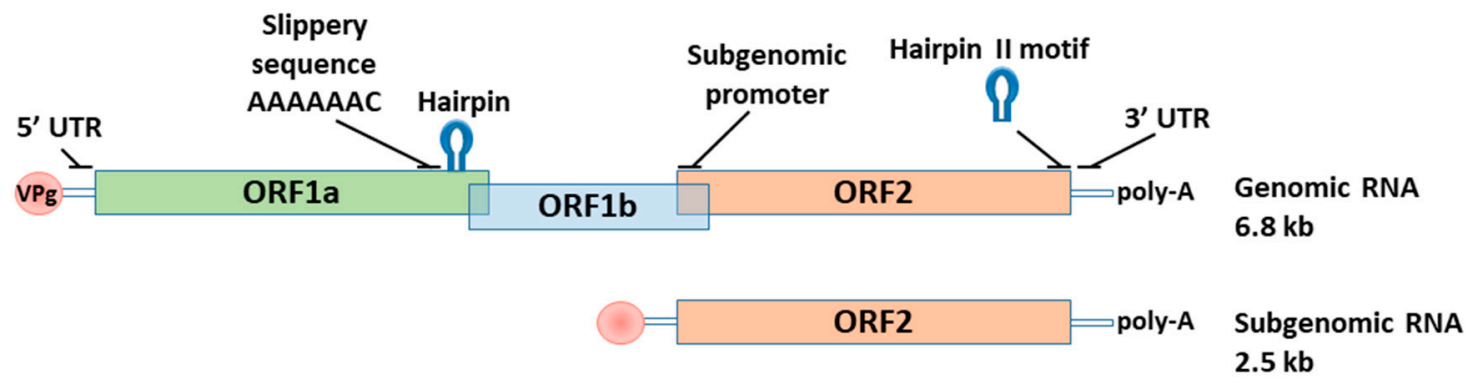

Figure 3. Genome structure of astrovirus. The hepanucleotide slippery sequence and the RNA hairpin structure acts as the frameshifting signal that produces ORF1b translation. ORF2 is a subset of sgRNA produced during virus replication.

HAstV was commonly associated with the incidence of acute gastroenteritis in young children, immunocompromised individuals, and the elderly. HAstV is responsible for sporadic non-bacterial diarrheal cases, representing up to $20 \%$ and $0.5-15 \%$ of related 
outbreaks [243-245]. HAstV is considered the second or third major cause of infantile gastroenteritis after rota- and calciviruses [246]. Nonetheless, regional studies demonstrate a significantly different relative prevalence of HAstV in water resources (Table 5) and clinical settings. For instance, in particular developing countries, $30 \%$ of all diarrheal cases were due to HAstV infection [94,247]. Moreover, HAstV was detected in rivers $(8.3-100 \%)$, seawater $(4-11 \%)$, raw sewage water $(40.2-100 \%)$, and treated effluents $(0-84 \%)$, as displayed in Table 2. Moreover, HAstV was detected at the highest concentration estimated, $4.3 \times 10^{7} \mathrm{GC} / \mathrm{L}$, in raw sewage water in Uruguay in comparison to other countries.

Gastroenteritis caused by HAstV is characterized by symptoms involving 2-3 daywatery diarrhea, vomiting, abdominal pain, malaise, and headache [248]. The incubation period is somewhat longer than gastroenteritis caused by other types of virus at an average of 4.5 days [96,249]. HAstV encompasses eight genotypes, HAstV-1 to HAstV-8 [250], while HAstV-1 is the most common genotype identified in both wastewater and stools [251].

Table 4. HAV abundance in water environments and prevalent genogroups.

\begin{tabular}{|c|c|c|c|c|c|c|c|}
\hline Country & Water Source & $\begin{array}{l}\text { Frequency } \\
\text { (\% Positive) }\end{array}$ & Study Period & Concentration & $\begin{array}{l}\text { Genotypes- } \\
\text { Subgenotype }\end{array}$ & Assessment Tools & Reference \\
\hline \multirow{3}{*}{ Bahrain } & $\begin{array}{l}\text { Raw sewage } \\
\text { water }\end{array}$ & $12.5 \%$ & \multirow{3}{*}{$\begin{array}{c}\text { January-February and } \\
\text { May-June }\end{array}$} & \multirow{3}{*}{-} & \multirow{3}{*}{-} & \multirow{3}{*}{ RT-PCR } & \multirow{3}{*}{ [224] } \\
\hline & $\begin{array}{c}\text { Tertiary treated } \\
\text { effluents }\end{array}$ & $0 \%$ & & & & & \\
\hline & $\begin{array}{c}\text { Bay } \\
\text { downstream } \\
\text { water (effluent } \\
\text { discharge) }\end{array}$ & $0 \%$ & & & & & \\
\hline \multirow{3}{*}{ Egypt } & $\begin{array}{l}\text { Irrigation } \\
\text { water }\end{array}$ & $34.4 \%$ & $\begin{array}{l}\text { September-December } \\
2017\end{array}$ & $\begin{array}{l}1.2 \times 10^{4} \\
\mathrm{GC} / \mathrm{L}^{\mathrm{a}}\end{array}$ & - & $\begin{array}{l}\text { One-step RT-PCR and } \\
\text { Real-Time PCR }\end{array}$ & {$[74]$} \\
\hline & $\begin{array}{l}\text { Raw sewage } \\
\text { water }\end{array}$ & $97.4 \%$ & \multirow{2}{*}{2014} & \multirow{2}{*}{-} & \multirow{2}{*}{ IB } & \multirow{2}{*}{$\begin{array}{l}\text { RT-PCR, cell culture and } \\
\text { direct sequencing }\end{array}$} & \multirow{2}{*}{ [225] } \\
\hline & $\begin{array}{l}\text { Treated } \\
\text { effluents }\end{array}$ & $47 \%$ & & & & & \\
\hline \multirow{4}{*}{ Tunisia } & $\begin{array}{l}\text { Raw sewage } \\
\text { water }\end{array}$ & $66.9 \%$ & \multirow{2}{*}{$\begin{array}{c}\text { December } \\
\text { 2009-December } 2010\end{array}$} & $\begin{array}{l}2.7 \times 10^{3} \\
\mathrm{GC} / \mathrm{mL}\end{array}$ & \multirow{2}{*}{$\begin{array}{l}\text { IA } \ddagger \text { and } \\
\text { IB- }\end{array}$} & \multirow{2}{*}{$\begin{array}{l}\text { One-step real-time } \\
\text { RT-qPCR, semi nested } \\
\text { RT-PCR and sequencing }\end{array}$} & \multirow{2}{*}{ [226] } \\
\hline & $\begin{array}{l}\text { Treated } \\
\text { effluents }\end{array}$ & $40.7 \%$ & & $\begin{array}{l}6.0 \times 10^{3} \\
\mathrm{GC} / \mathrm{mL}\end{array}$ & & & \\
\hline & $\begin{array}{l}\text { Raw sewage } \\
\text { water }\end{array}$ & $68.3 \%$ & \multirow{2}{*}{$2007-2008$} & $\begin{array}{l}3.5 \times 10^{5} \\
\mathrm{GC} / \mathrm{L}^{\mathrm{a}}\end{array}$ & \multirow{2}{*}{$\mathrm{IA} \ddagger$ and IB } & \multirow{2}{*}{$\begin{array}{l}\text { RT-PCR, nested RT-PCR, } \\
\text { sequencing, qPCR }\end{array}$} & \multirow{2}{*}{ [227] } \\
\hline & $\begin{array}{c}\text { Treated } \\
\text { effluents }\end{array}$ & $64.7 \%$ & & $\begin{array}{l}2.5 \times 10^{5} \\
\mathrm{GC} / \mathrm{L}^{\mathrm{a}}\end{array}$ & & & \\
\hline \multirow{4}{*}{ Uruguay } & $\begin{array}{l}\text { Surface water } \\
\text { (rivers and } \\
\text { logoon) }\end{array}$ & $13.95 \%$ & \multirow{4}{*}{ 2009-2012 } & $\begin{array}{c}3.7 \times 10^{3} \\
\mathrm{GC} / \mathrm{L}\end{array}$ & \multirow{4}{*}{-} & \multirow{4}{*}{$\begin{array}{l}\text { qualitative PCR and } \\
\text { TaqMan-based qPCR }\end{array}$} & \multirow{4}{*}{ [228] } \\
\hline & Drinking water & $0 \%$ & & & & & \\
\hline & $\begin{array}{l}\text { Raw sewage } \\
\text { water }\end{array}$ & $2.3 \%$ & & - & & & \\
\hline & $\begin{array}{c}\text { Treated } \\
\text { effluents }\end{array}$ & $0 \%$ & & & & & \\
\hline \multirow{3}{*}{$\begin{array}{l}\text { South } \\
\text { Africa }\end{array}$} & $\begin{array}{l}\text { Surface water } \\
\text { (Rivers and } \\
\text { dams) }\end{array}$ & $76 \%$ & \multirow{2}{*}{$\begin{array}{l}\text { August 2010-December } \\
2011^{\curlyvee} \text {, and January } \\
2012 \text {-August } 2012^{¥}\end{array}$} & \multirow[t]{2}{*}{-} & \multirow[t]{2}{*}{ IB } & \multirow{2}{*}{$\begin{array}{c}\text { One-step RT-qPCR, } \\
\text { nested PCR, amplicon } \\
\text { cloning and sequencing }\end{array}$} & \multirow[t]{2}{*}{ [229] } \\
\hline & $\begin{array}{c}\text { Treated } \\
\text { effluents }\end{array}$ & $37 \%$ & & & & & \\
\hline & $\begin{array}{l}\text { Irrigation } \\
\text { water }\end{array}$ & $73 \%$ & $\begin{array}{c}\text { January, March and } \\
\text { May } 2013\end{array}$ & $\begin{array}{l}2.37 \times 10^{5} \\
\mathrm{GC} / \mathrm{L}^{\mathrm{b}}\end{array}$ & $\mathrm{V}$ & $\begin{array}{l}\text { real-time RT-PCR, } \\
\text { molecular cloning and } \\
\text { sequencing }\end{array}$ & [230] \\
\hline
\end{tabular}


Table 4. Cont.

\begin{tabular}{|c|c|c|c|c|c|c|c|}
\hline Country & Water Source & $\begin{array}{l}\text { Frequency } \\
(\% \text { Positive })\end{array}$ & Study Period & Concentration & $\begin{array}{l}\text { Genotypes- } \\
\text { Subgenotype }\end{array}$ & Assessment Tools & Reference \\
\hline Pakistan & $\begin{array}{l}\text { Surface and } \\
\text { subsurface water }\end{array}$ & $12.63 \%$ & June 2014-May 2015 & - & - & RT-PCR & [231] \\
\hline USA & Well water & $60 \%$ & $\begin{array}{c}\text { September } \\
\text { 1995-December } 1995\end{array}$ & - & $1 \mathrm{~A}$ & $\begin{array}{l}\text { IC (immunocapture)-RT- } \\
\text { PCR and amplicon } \\
\text { sequencing }\end{array}$ & [232] \\
\hline \multirow{2}{*}{ Brazil } & River water & $1.19 \%$ & 2012-2014 & $\begin{array}{c}1.5 \times 10^{4} \\
\mathrm{GC} / \mathrm{L}\end{array}$ & - & $\begin{array}{c}\text { RT-TaqMan } \\
\text { probe-mediated qPCR } \\
\text { and ICC-RT-qPCR }\end{array}$ & [233] \\
\hline & $\begin{array}{l}\text { Recreational } \\
\text { water (Lagoons } \\
\text { and beaches) }\end{array}$ & $0 \%$ & March 2015-July 2016 & - & - & RT-PCR & [83] \\
\hline \multirow{6}{*}{ Italy } & $\begin{array}{l}\text { Raw sewage } \\
\text { water }\end{array}$ & $28.16 \%$ & \multirow{3}{*}{ 2015-2018 } & & & & \\
\hline & $\begin{array}{l}\text { Coastal } \\
\text { discharge } \\
\text { water }\end{array}$ & $3.97 \%$ & & & $\mathrm{IA}^{\ddagger}$ and $\mathrm{IB}$ & $\begin{array}{l}\text { RT-nested-PCR and } \\
\text { amplicon sequencing }\end{array}$ & [199] \\
\hline & Seawater & $12.8 \%$ & & & & & \\
\hline & $\begin{array}{l}\text { Raw sewage } \\
\text { water }\end{array}$ & $33.3 \%$ & \multirow{3}{*}{$\begin{array}{l}\text { January-December } \\
2013\end{array}$} & \multirow{3}{*}{-} & IA and IB $\ddagger$ & \multirow{3}{*}{$\begin{array}{l}\text { nested RT-PCR and } \\
\text { sequencing }\end{array}$} & \multirow{3}{*}{ [234] } \\
\hline & $\begin{array}{l}\text { Treated } \\
\text { effluents }\end{array}$ & $14.3 \%$ & & & $\mathrm{IA} \ddagger$ and IB & & \\
\hline & River water & $7.4 \%$ & & & IB & & \\
\hline \multirow{2}{*}{ Spain } & $\begin{array}{l}\text { Raw sewage } \\
\text { water }\end{array}$ & $1.75 \%$ & \multirow[b]{2}{*}{2019} & \multirow[b]{2}{*}{-} & \multirow[b]{2}{*}{-} & \multirow[b]{2}{*}{ Real-time RT-PCR } & \multirow{2}{*}{ [235] } \\
\hline & $\begin{array}{l}\text { Tertiary- } \\
\text { treated } \\
\text { effluent }\end{array}$ & $0.35 \%$ & & & & & \\
\hline $\begin{array}{l}\text { Hong } \\
\text { Kong }\end{array}$ & Seawater $\S$ & $57.14 \%$ & 2011 & $\begin{array}{l}1.028 \times 10^{3} \\
\text { particle } / \mathrm{L}^{\mathrm{b}}\end{array}$ & IB & $\begin{array}{c}\text { RT-PCR, amplicon } \\
\text { cloning, sequencing and } \\
\text { TaqMan real-time PCR }\end{array}$ & [236] \\
\hline Canada & Drinking water & $10 \%$ & 1974-2001 & - & - & $\diamond$ & [237] \\
\hline \multirow{2}{*}{ France } & $\begin{array}{l}\text { Raw sewage } \\
\text { water }\end{array}$ & $59.3 \%$ & \multirow{2}{*}{$\begin{array}{l}\text { October 2014-October } \\
2015\end{array}$} & \multirow[t]{2}{*}{ - } & $\begin{array}{l}\text { IIIA and } \\
\text { IA }\end{array}$ & \multirow{2}{*}{$\begin{array}{l}\text { RT-PCR and sanger } \\
\text { sequencing }\end{array}$} & \multirow{2}{*}{ [23] } \\
\hline & $\begin{array}{l}\text { Treated } \\
\text { effluents }\end{array}$ & $19.2 \%$ & & & - & & \\
\hline Sweden & $\begin{array}{l}\text { Raw sewage } \\
\text { water }\end{array}$ & $100 \%$ & January-May 2013 & $\begin{array}{l}1.4 \times 10^{4} \\
\text { virus } / \mathrm{L}^{\mathrm{b}}\end{array}$ & - & $\begin{array}{c}\text { Two-step real-time } \\
\text { RT-qPCR }\end{array}$ & [92] \\
\hline
\end{tabular}

${ }^{a}$ : mean HAV concentration, ${ }^{b}$ : maximum HAV concentration. ${ }^{\Upsilon}$ : for surface water samples, ${ }^{\ddagger}$ : for WWTP outflow water, ${ }^{\ddagger}$ : dominant genotype, ${ }^{\S}$ : sewage polluted sea water, ${ }^{\diamond}$ : outbreaks data summary, GC: genome copy, (-): not defined.

Table 5. Prevalence of waterborne astroviruses, predominant genogroups, and assessment tools.

\begin{tabular}{|c|c|c|c|c|c|c|c|}
\hline Country & Water Source & $\begin{array}{c}\text { Frequency ( } \% \\
\text { Positive) }\end{array}$ & Study Period & Concentration & $\begin{array}{l}\text { Genogroups- } \\
\text { Genotypes }\end{array}$ & Assessment Tools & Reference \\
\hline \multirow{4}{*}{ Egypt } & $\begin{array}{c}\text { Raw sewage } \\
\text { water }\end{array}$ & $40.2 \%$ & \multirow[t]{2}{*}{ April 2017-March 2018} & \multirow[t]{2}{*}{-} & \multirow[t]{2}{*}{$A$ and $B$} & \multirow[t]{2}{*}{ Semi-nested RT-PCR } & \multirow[t]{2}{*}{ [171] } \\
\hline & River & $8.3 \% *-25 \% * *$ & & & & & \\
\hline & $\begin{array}{c}\text { Urban sewage } \\
\text { water }\end{array}$ & $58.3 \%$ & \multirow{2}{*}{$\begin{array}{l}\text { October 2017-September } \\
2018\end{array}$} & \multirow[t]{2}{*}{-} & $\mathrm{B} \ddagger$ and $\mathrm{A}$ & \multirow[t]{2}{*}{ Semi-nested RT-PCR } & \multirow[t]{2}{*}{ [172] } \\
\hline & Treated effluent & $33.3 \%$ & & & $\mathrm{~A}$ and $\mathrm{B}$ & & \\
\hline
\end{tabular}


Table 5. Cont.

\begin{tabular}{|c|c|c|c|c|c|c|c|}
\hline Country & Water Source & $\begin{array}{l}\text { Frequency } \\
\text { (\% Positive) }\end{array}$ & Study Period & Concentration & $\begin{array}{l}\text { Genogroups- } \\
\text { Genotypes }\end{array}$ & Assessment Tools & Reference \\
\hline Japan & $\begin{array}{l}\text { Raw Sewage } \\
\text { water }\end{array}$ & $91.67 \%$ & July 2015-June 2016 & - & $\begin{array}{l}\text { A(1), MLB1 } \\
\ddagger \text { and MLB2 }\end{array}$ & RT-PCR and sequencing & [252] \\
\hline \multirow{4}{*}{ Kenya } & $\begin{array}{l}\text { Raw sewage } \\
\text { water }\end{array}$ & $98 \% d$ & April 2015-April 2016 & $30.8^{f}$ & - & Real-time RT-PCR & [253] \\
\hline & Urban river & $60 \%{ }^{b}$ & \multirow{3}{*}{ May 2007-February 2008} & \multirow{3}{*}{-} & \multirow{3}{*}{-} & \multirow{3}{*}{$\begin{array}{l}\text { Qualitative singleplex } \\
\text { real-time RT-PCR }\end{array}$} & \multirow{3}{*}{ [254] } \\
\hline & Rural river & $41.7 \%$ & & & & & \\
\hline & $\begin{array}{l}\text { Urban sewage } \\
\text { water }\end{array}$ & $87.5 \%$ b & & & & & \\
\hline Uruguay & $\begin{array}{l}\text { Raw sewage } \\
\text { water }\end{array}$ & $45 \%$ & $\begin{array}{l}\text { March 2011-February } \\
2012\end{array}$ & $4.3 \times 10^{7} \mathrm{GC} / \mathrm{L}^{\mathrm{a}}$ & - & $\begin{array}{c}\text { Qualitative RT-PCR and } \\
\text { qPCR }\end{array}$ & [255] \\
\hline \multirow{2}{*}{$\begin{array}{l}\text { South } \\
\text { Africa }\end{array}$} & River water & $21.6 \%$ & \multirow{2}{*}{ June 1997-May 1998} & \multirow{2}{*}{-} & \multirow{2}{*}{-} & \multirow{2}{*}{$\begin{array}{l}\text { Cell culture, RT-PCR, } \\
\text { dot-blot Hybridisation assay }\end{array}$} & \multirow{2}{*}{ [256] } \\
\hline & Dam water & $5.9 \%$ & & & & & \\
\hline \multirow{2}{*}{ Nepal } & Ground water & $8.1 \%$ & \multirow{2}{*}{ August 2009-May 2011} & \multirow{2}{*}{-} & $\begin{array}{l}\mathrm{A}(1,2,4,5 \\
\text { and } 8) \neq \\
\text { and MLB }\end{array}$ & \multirow{2}{*}{$\begin{array}{l}\text { RT- semi-nested PCR and } \\
\text { Next-generation amplicon } \\
\text { sequencing }\end{array}$} & \multirow{2}{*}{ [257] } \\
\hline & River water & $100 \%$ & & & $\begin{array}{l}\mathrm{A}, \mathrm{B}, \mathrm{MLB} \\
\text { and VA }\end{array}$ & & \\
\hline \multirow[t]{2}{*}{ USA } & $\begin{array}{l}\text { Raw sewage } \\
\text { water }\end{array}$ & $75 \%$ b & \multirow[t]{2}{*}{ August 2011 and July 2012} & \multirow[t]{2}{*}{-} & \multirow{2}{*}{$\begin{array}{l}\mathrm{A} \ddagger, \mathrm{B}, \mathrm{MLB} \\
\text { and VA }\end{array}$} & \multirow{2}{*}{$\begin{array}{l}\text { RT- semi-nested PCR and } \\
\text { Next-generation amplicon } \\
\text { sequencing }\end{array}$} & \multirow[t]{2}{*}{ [257] } \\
\hline & Treated effluent & $63 \% \mathrm{~b}$ & & & & & \\
\hline Brazil & $\begin{array}{l}\text { Surface water } \\
\text { (basins) }\end{array}$ & $15.4 \%{ }^{b}$ & August 2004-June 2005 & - & $\mathrm{A}(1)$ & $\begin{array}{l}\text { RT-PCR, nested PCR and } \\
\text { amplicon sequencing }\end{array}$ & [258] \\
\hline \multirow{4}{*}{ Italy } & $\begin{array}{l}\text { Seawater } \\
\text { (receiving } \\
\text { treated water) }\end{array}$ & $9 \%$ & \multirow{4}{*}{$\begin{array}{l}\text { February 2019-August } \\
2020\end{array}$} & \multirow{4}{*}{$1 \times 10^{2} \mathrm{GC} / \mathrm{L}$} & \multirow{4}{*}{$\mathrm{A}(1)$} & \multirow{4}{*}{$\begin{array}{c}\text { Real-time (RT) qPCR, } \\
\text { OneStep RT-PCR, nested or } \\
\text { semi-nested PCR and } \\
\text { sequencing }\end{array}$} & \multirow{4}{*}[259]{} \\
\hline & $\begin{array}{c}\begin{array}{c}\text { Seawater } \\
\text { (receiving } \\
\text { non-treated } \\
\text { water) }\end{array} \\
\end{array}$ & $7 \%$ & & & & & \\
\hline & $\begin{array}{c}\text { Seawater } \\
\text { (receiving rain } \\
\text { drain and raw } \\
\text { water) }\end{array}$ & $4 \%$ & & & & & \\
\hline & $\begin{array}{l}\text { Seawater } \\
\text { receiving mixed } \\
\text { waters }\end{array}$ & $11 \%$ & & & & & \\
\hline UK & Water supplies & $1 \%$ & 1992-2003 & - & - & $\ddagger$ & [260] \\
\hline China & $\begin{array}{l}\text { Sewage } \\
\text { treatment } \\
\text { plant water }\end{array}$ & $6.3 \%$ & $\begin{array}{l}\text { November 2006-October } \\
2007\end{array}$ & - & - & RT-nested PCR & [261] \\
\hline \multirow[b]{2}{*}{ Canada } & River upstream & $42 \%{ }^{b}$ & \multirow{2}{*}{ June 2012-May 2013} & $\begin{array}{l}\text { 2.52 } \log _{10} \mathrm{GE}^{\S} \\
\text { copies } / \mathrm{L}^{\mathrm{a}}\end{array}$ & & & \\
\hline & $\begin{array}{c}\text { River } \\
\text { downstream }\end{array}$ & $92 \%$ b & & $\begin{array}{l}4.1 \log _{10} \mathrm{GE}^{\S} \\
\text { copies } / \mathrm{L}^{\mathrm{a}}\end{array}$ & - & Two-step RT-qPCR & [89] \\
\hline & River water & $36 \%$ & & $10^{3} \mathrm{GC} / \mathrm{L}^{\mathrm{a}}$ & & & \\
\hline France & Tributaries water & $16 \%$ & May 2013-May 2014 & $10^{3} \mathrm{GC} / \mathrm{L}^{\mathrm{a}}$ & - & Real-time RT-qPCR & [262] \\
\hline & Treated effluents & $84 \%$ & & $10^{4} \mathrm{GC} / \mathrm{L}^{\mathrm{a}}$ & & & \\
\hline & $\begin{array}{c}\text { Raw sewage } \\
\text { water }\end{array}$ & $100 \%$ & & $\begin{array}{l}1.1 \times 10^{6} \\
\mathrm{GC} / \mathrm{mL}^{\mathrm{a}}\end{array}$ & & & \\
\hline Sweden & $\begin{array}{l}\text { Conventionally } \\
\text { treated effluents }\end{array}$ & $33.3 \%$ & $\begin{array}{l}\text { November-December } \\
2015\end{array}$ & $\begin{array}{l}1.8 \times 10^{2} \\
\mathrm{GC} / \mathrm{mL}\end{array}$ & $\mathrm{A}(4)$ & $\begin{array}{l}\text { RT-nested PCR, Library } \\
\text { construction, NGS } \\
\text { sequencing and qPCR }\end{array}$ & [91] \\
\hline & $\begin{array}{l}\text { Ozone treated } \\
\text { effluents }\end{array}$ & $0 \%$ & & - & & & \\
\hline & $\begin{array}{l}\text { Raw sewage } \\
\text { water }\end{array}$ & $100 \%$ & January-May 2013 & $\begin{array}{l}4.6 \times 10^{5} \\
\text { virus } / L^{c}\end{array}$ & - & Two-step real-time RT-qPCR & [92] \\
\hline
\end{tabular}

${ }^{\mathrm{a}}$ : maximum astrovirus concentration, ${ }^{\mathrm{b}}$ : maximum astrovirus detection frequency, ${ }^{\mathrm{c}}$ : mean astrovirus concentration, ${ }^{\mathrm{d}}$ : mean astrovirus frequency, GC: genome copy. *: before mixing with wastewater **: after mixing with wastewater, $\$$ : genome equivalent, $\ddagger$ : dominant genogroup/genotype, $\int$ : average quantification cycle $(\mathrm{Cq})$, where low $\mathrm{Cq}$ values reflects high virus concentrations and vice versa, $\neq$ : review study of epidemiological and microbiological characteristics of 89 waterborne infectious intestinal outbreaks affecting England and Wales, (-): not defined. 


\section{Public Exposure to Municipal Wastewater}

People are exposed to wastewater by various means (recreational activities, food production, and agriculture). However, the infection risk due to waterborne enteric viruses is dependent on the infectious enteric viruses' prevalence or their infectivity in various water environments that humans interact with (Table 6). For instance, infection risk due to HAdV in drinking water accounted for $10^{-4}$ /year for each person, which was quite similar to astrovirus infection risk detected earlier in surface water in Mexico [87,263]. Moreover, HAdV and EV were found to be of the highest infectivity rate in secondary treated water and even in post-disinfection final effluent confirmed by cytopathic effect detection. However, a lower infectivity rate of $\mathrm{HAdV}$ and $\mathrm{EV}$ was detected in raw sewage $(64 \%)$ and dam water $(\sim 65 \%)$, respectively (Table 6$)$. Furthermore, infection risk was more reduced in surface water $(10,000 x / 180$ days and $10,000 x / 30$ days) than in ground water (1000x/'213 days and 10x/30 days) in the case of $R V$ and AstV, respectively. The main exposure routes frequently include recreational activities and surface water drinking. Moreover, shellfish production is regarded as an indirect route of exposure, since molluscs are filter feeders and, consequently, contaminated water pathogens become concentrated and lead to consumer infection $[264,265]$. Moreover, enteric viruses were detected using nested PCR for entero-, norwalk-like, and hepatitis A viruses and real-time PCR for adenovirus in 50\% to $60 \%$ of the total mussel samples (18) obtained from a bioremediation mussel farm [266]. Notably, non-enveloped viruses, such as noroviruses and the hepatitis A virus, can survive in the bivalves' tissues and are highly resilient to degradation [267,268]. Moreover, virus particle size was found to determine whether the particle is degradation resistant or susceptible [265]. For example, $<200 \mathrm{~nm}$ VLPs are typically of higher degradation resistance when compared to bacteria [269]. Human infectious diseases owing to consumption of contaminated filter-feeders and recreational activities in wastewater-polluted coastal waters account for USD 12 billion annually [270]. Moreover, wastewater-mediated irrigation, in particular sprinkler irrigation, generates aerosols that can cause infection upon direct exposure or ingestion of irrigated crops [271]. It is important to note that the RNA of the pandemic SARS-CoV-2 was detected in treated wastewater, representing a critical issue for usage in irrigation [272]. Therefore, SARS-CoV-2 RNA was investigated in various water resources for their incidence frequency (Figure 4) and prevalence using different genes (e.g., RdRP, S, N1, N2, N3, ORF1ab, and E) as genetic tracers [273-285]. However, the highest SARS-CoV-2 detection specificity was obtained when RdRP was applied in RT-qPCR and compared to other SARS-CoV-2 genes [286]. Furthermore, detection of SARS-CoV-2 RNA in treated wastewater is not usually associated with SARS-CoV-2 infection risk, as reported in treated sewage of nine WWTPs in Germany [286]. This could be owing to the significantly higher persistence of SARS-CoV-2 RNA than infectious SARS-CoV-2 in water environments. Moreover, the persistence of infectious SARS-CoV-2 in water environments is reliant on many factors, such as water source, temperature, and the initial virus titer. For instance, a T90 of infectious SARS-CoV-2 at room temperature was found 1.7 and 1.5 days in tap water and wastewater, respectively, that extended to 7 days when a higher initial titer $\left(10^{5} \mathrm{TCID} 50 / \mathrm{mL}\right)$ was applied [26]. By comparison, the T90 values declined in wastewater to a total of $15 \mathrm{~min}$ and $2 \mathrm{~min}$ at 50 and $70{ }^{\circ} \mathrm{C}$, respectively [26]. Toilet flushing and groundwater production render other routes of direct exposure to wastewater $[100,287]$. 
Table 6. Infectivity of enteric viruses in different water resources.

\begin{tabular}{|c|c|c|c|c|c|c|c|c|c|}
\hline \multirow{3}{*}{ Water Source } & \multirow{3}{*}{ Virus } & \multirow{3}{*}{ Genotype } & \multirow{3}{*}{ Infectivity Rate } & \multirow{3}{*}{ Number of Samples } & \multicolumn{3}{|c|}{ Infection Risk (IR) $\diamond$} & \multirow{3}{*}{ Detection Method } & \multirow{3}{*}{ Reference } \\
\hline & & & & & \multirow{2}{*}{ IR/person } & \multicolumn{2}{|c|}{ Infection Risk Reduction } & & \\
\hline & & & & & & Period (days) & RA ( $\log _{10}$ or fold) & & \\
\hline Recreational water & HAdV & $\mathrm{C}$ & $1 \mathrm{IVP} / 90 \%$ of sites * & $\begin{array}{c}159 \text { (144 [9 sites] and } \\
15 \text { [3 sites]) }\end{array}$ & & - & & $\begin{array}{c}\text { Integrated cell } \\
\text { culture-qPCR assay }\end{array}$ & [83] \\
\hline Raw sewage water & \multirow{2}{*}{ HAV } & \multirow{2}{*}{ IIIA and IA } & $64.3 \%(9 / 14)^{* *}$ & 14 & \multirow{2}{*}{\multicolumn{2}{|c|}{ - }} & & \multirow{2}{*}{ Cell culture } & \multirow{2}{*}{ [23] } \\
\hline Treated effluents & & & $100 \%(1 / 1)^{* *}$ & 1 & & & & & \\
\hline $\begin{array}{c}\text { Drinking water } \\
\left(40 \mathrm{~mJ} / \mathrm{cm}^{2} \text { UV-treated }\right)\end{array}$ & \multirow{2}{*}{ HAdV } & \multirow[t]{2}{*}{$F(40,41)$} & \multirow{2}{*}{$1 / 1700\left(5.88 \times 10^{-4}\right)^{* * *}$} & \multirow[t]{2}{*}{35} & \multirow[t]{2}{*}{$10^{-4} /$ year $\$$} & \multirow[t]{2}{*}{-} & $5^{Y}$ & \multirow{2}{*}{$\begin{array}{l}\text { Integrated cell } \\
\text { culture PCR }\end{array}$} & \multirow[t]{2}{*}{ [87] } \\
\hline $\begin{array}{c}\text { Drinking water } \\
\text { (73 } \mathrm{mJ} / \mathrm{cm}^{2} \text { UV-treated) }\end{array}$ & & & & & & & $6.5^{Y}$ & & \\
\hline \multirow{3}{*}{ Groundwater } & \multirow{6}{*}{ RV } & \multirow{6}{*}{-} & & \multirow{3}{*}{35} & \multirow{6}{*}{-} & 90 & $100^{¥}$ & \multirow{8}{*}{$\begin{array}{l}\text { Immunoperoxidase focus } \\
\text { infectious assay }\end{array}$} & \multirow{8}{*}{ [263] } \\
\hline & & & & & & 150 & \multirow{2}{*}{$1000^{¥}$} & & \\
\hline & & & - & & & $\sim 213$ & & & \\
\hline \multirow{3}{*}{ Surface water } & & & & \multirow{3}{*}{35} & & 30 & $40^{¥}$ & & \\
\hline & & & & & & 150 & $1500^{¥}$ & & \\
\hline & & & & & & 180 & $10,000^{¥}$ & & \\
\hline Ground water & & & & 20 & - & 30 & $10^{¥}$ & & \\
\hline Surface water & & & & 5 & $10^{-4 \ddagger}$ & 30 & $10,000^{¥}$ & & \\
\hline Pre-DIS influent & $H A d V$ and $F Y$ & - & $100 \%+$ & 30 & - & - & - & Coll culture & [288] \\
\hline Post-DIS influent & HAdV and EV & 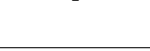 & $100 \%$ & 30 & 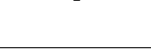 & 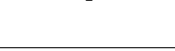 & $4.2^{Y, \mathrm{a}}$ & Cell culture & {$[200]$} \\
\hline Raw sewage water & HAdV & $\mathrm{F}$ & $64 \%(32 / 50) * *$ & 50 & - & - & - & Cell culture & [289] \\
\hline Dam water & EV & & $\begin{array}{c}64.6 \%(31 / 48)-66.7 \% \\
(44 / 66)^{* *}\end{array}$ & $\begin{array}{l}114 \text { (48 samples at } \\
\text { Jan.-Dec. } 2012 \text { and } \\
66 \text { samples at Oct. } \\
\text { 2013-Oct. 2015) }\end{array}$ & - & - & - & $\begin{array}{c}\text { Cytopathic effect } \\
\text { detection and Direct } \\
\text { immunofluorescence } \\
\text { assay }\end{array}$ & [290] \\
\hline
\end{tabular}

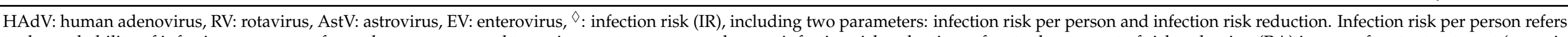

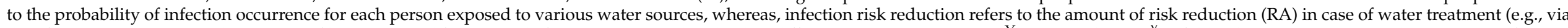

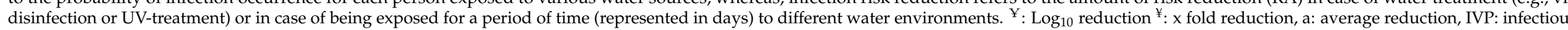

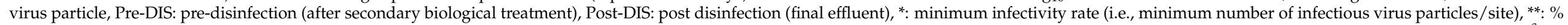

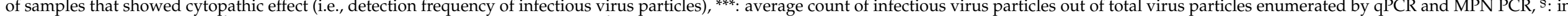
all four-treatment scenarios, ${ }^{\ddagger}$ : residual infectivity ( $\mathrm{x}$ of the original virus titer) ${ }^{\dagger}:$ defined by cytopathic effect detection, $(-)$ : not defined. 


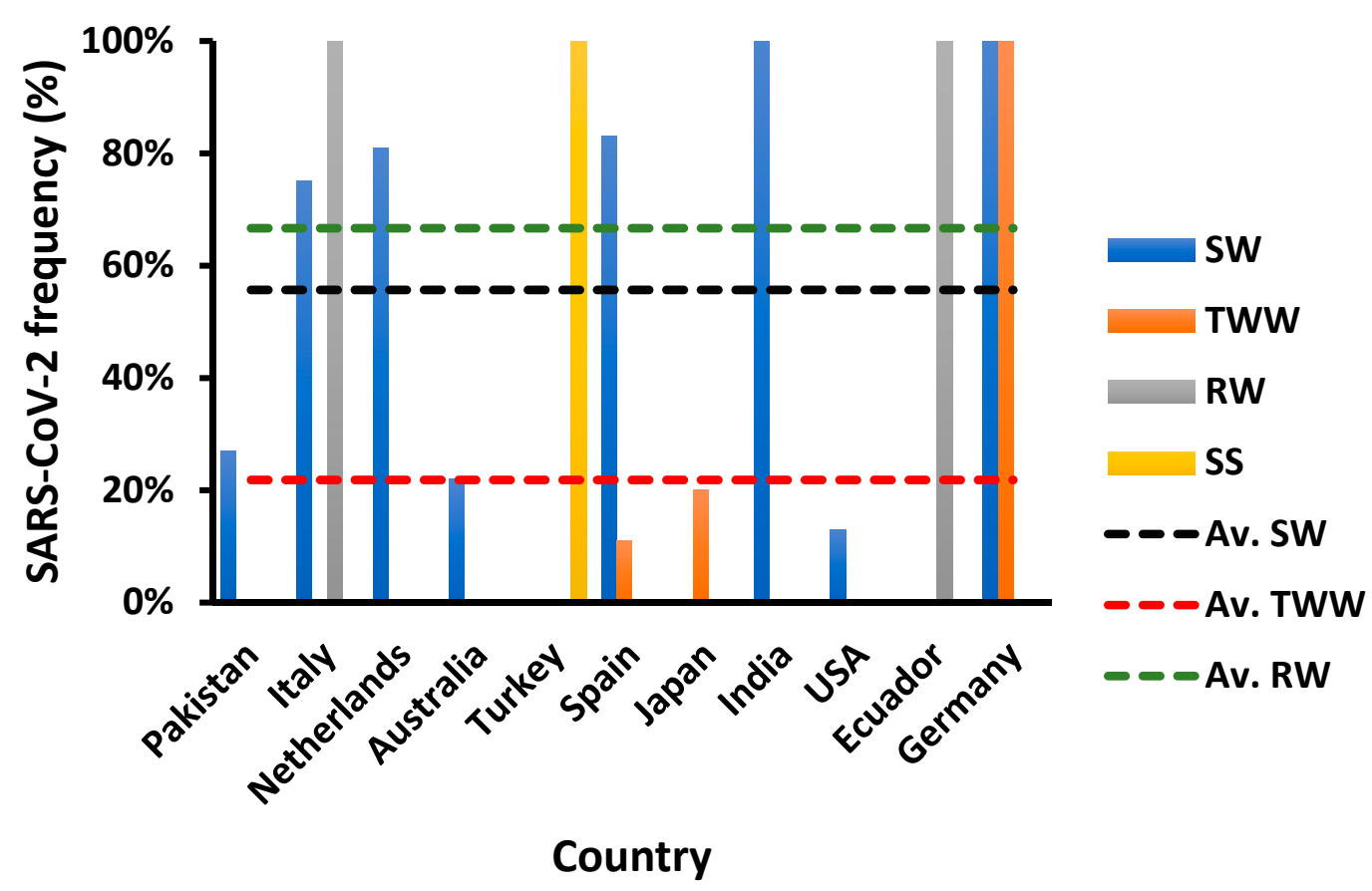

Figure 4. Frequency of SARS-CoV-2 RNA in various water environments [274,276-278,281-286,291]. SW: sewage water, TWW: Treated wastewater, RW: River water, SS: Wastewater sludge samples, Av.: Average frequency, for example, Av. SW: Average frequency of SARS-CoV-2 RNA in SW of countries that involved SW in their evaluation.

\section{Discharge of Wastewater}

Wastewater is commonly discharged into surface water resources. In addition to the public health concerns, fecal contamination of wastewater can negatively influence water environments essential for fishing, drinking water, and recreation. Enteric viruses are considered the main cause of waterborne illnesses associated with recreational water, including pools, spas, rivers, etc., and can reach waters via the accidental release of feces or body fluids [292]. Moreover, a surge in non-enteric diseases was reported to arise from wastewater contaminated with significant viral contamination [24,25]. Wastewater treatment (WWT) performance guidelines were established for reclamation and reuse (Table 7). These guidelines are concerned with microorganism levels and the degree of treatment, whereas receiving waters risk management mainly depends on fecal indicator bacteria monitoring [293]. Unfortunately, these bacterial indicators cannot meet the full criteria of the ideal water quality indicators [294]. On the other hand, excreted enteric viruses can be detected in wastewater, but a wastewater treatment plant (WWTP) may not completely eliminate viruses in terms of their concentration and infectivity, thus demonstrating a continued water-related health risk [295]. Furthermore, enteric virus presence in water does not necessarily link to the bacterial indicators' detection as Escherichia coli and coliforms [296]. Additionally, bacteriophage survival in water is more similar to human enteric viruses than the presently used bacterial indicators [293]. For instance, cross-assembly phage is currently implemented alongside pepper mild mottle virus (PMMoV) as the microbial source tracks markers simultaneously in this toolbox approach. This is owing to their inclusive distribution, associated with ever higher densities in sewage, than other detected viruses and the fact they follow a similar pattern to enteric viruses prevalence in different water bodies. Consequently, they are efficient as indicators of virus-mediated fecal pollution in lakes, rivers, and recreational waters [297-301]. Thus, traceability procedures provide a mandate to determine fecal contamination sources so that the risk can be assessed to initiate a proper water management to counteract it at its source. 
Table 7. Microbial guidelines for wastewater reuse.

\begin{tabular}{|c|c|c|c|c|}
\hline Usage & $\begin{array}{l}\text { Guideline } \\
\text { Category }\end{array}$ & Allowed Limit & Average Limit & Reference \\
\hline Irrigation (unrestricted) & Enteric viruses & $<2$ Virus/50 L & - & [302] \\
\hline $\begin{array}{l}\text { Toilet flushing, primary } \\
\text { contact recreation, food } \\
\text { aquaculture and } \\
\text { car wash }\end{array}$ & Total coliform & $<10 \mathrm{cfu} / 100 \mathrm{~mL}$ & - & [303] \\
\hline Irrigation (unrestricted) & Total coliform & $<10 \mathrm{cfu} / 100 \mathrm{~mL}$ & - & [304] \\
\hline $\begin{array}{l}\text { Gardens with access, } \\
\text { ponds parks, crops and } \\
\text { secondary contact } \\
\text { recreation }\end{array}$ & Total coliform & $<100 \mathrm{cfu} / 100 \mathrm{~mL}$ & - & \multirow{3}{*}{ [305] } \\
\hline $\begin{array}{l}\text { Gardens and parks with } \\
\text { no public access during } \\
\text { irrigation and passive } \\
\text { recreation }\end{array}$ & Total coliform & $<1000 \mathrm{cfu} / 100 \mathrm{~mL}$ & - & \\
\hline $\begin{array}{l}\text { Non-food crops, Pasture } \\
\text { and fodder irrigation }\end{array}$ & Total coliform & $<10,000 \mathrm{cfu} / 100 \mathrm{~mL}$ & - & \\
\hline Food crops & Total coliform & $<23 \mathrm{cfu} / 100 \mathrm{~mL}$ & $2.2 \mathrm{cfu} / 100 \mathrm{~mL}$ & \multirow{3}{*}{ [304] } \\
\hline Non-food crops & Total coliform & $<240 \mathrm{cfu} / 100 \mathrm{~mL}$ & $23 \mathrm{cfu} / 100 \mathrm{~mL}$ & \\
\hline $\begin{array}{l}\text { Recreational reuse } \\
\text { (unrestricted) }\end{array}$ & Total coliform & $<240 \mathrm{cfu} / 100 \mathrm{~mL}$ & $23 \mathrm{cfu} / 100 \mathrm{~mL}$ & \\
\hline Irrigation (unrestricted) & Fecal coliform & $<1000 \mathrm{cfu} / 100 \mathrm{~mL}$ & - & [305] \\
\hline Food crops & Fecal coliform & $<400 \mathrm{cfu} / 100 \mathrm{~mL}$ & $200 \mathrm{cfu} / 100 \mathrm{~mL}$ & \multirow{3}{*}{ [304] } \\
\hline Non-food crops & Fecal coliform & $<400 \mathrm{cfu} / 100 \mathrm{~mL}$ & $200 \mathrm{cfu} / 100 \mathrm{~mL}$ & \\
\hline $\begin{array}{l}\text { Recreational reuse } \\
\quad \text { (unrestricted) }\end{array}$ & Fecal coliform & $<23 \mathrm{cfu} / 100 \mathrm{~mL}$ & $2.2 \mathrm{cfu} / 100 \mathrm{~mL}$ & \\
\hline Irrigation (unrestricted) & Fecal coliform & $<1 \mathrm{cfu} / 100 \mathrm{~mL}$ & - & [302] \\
\hline Irrigation (unrestricted) & Nematode egg & $<2 \mathrm{egg} / \mathrm{L}$ & - & [305] \\
\hline Irrigation (unrestricted) & (Oo)cysts & $<1$ cyst/50 L & - & [302] \\
\hline
\end{tabular}

(-): not applicable.

\section{Reuse of Treated Water}

The reusing of wastewater is determined by economic factors as it is often either used for the recirculation of organic matter, to act as natural fertilizers, or due to a shortage of water resources $[27,28]$. For instance, wastewater and greywater (households' wastewater with no fecal contamination) were used for irrigation of agricultural products, as well as indoor activities involving toilet flushing and even for potable use [17-21]. However, intensive treatment measures are required to meet the suggested wastewater reuse guidelines and, in particular, for greywater in which significant coliform loads may exist. However, the performance of treatment procedures relying on coliform elimination may be biased and exaggerated owing to the capability of these bacteria to multiply within the greywater system.

Wastewater reuse is currently a frequent practice in many countries. For example, treated wastewater is utilized in agriculture and landscaping in many countries, including Egypt, Saudi Arabia, Italy, Cyprus, Malta, Spain, and the USA [306-310]. It is, for instance, used in Egypt for the irrigation of sandy soils to raise the organic matter content of soil and improve the capacity of cation exchange [311]. In Saudi Arabia in 2010, 25\% of treated wastewater was used to irrigate landscapes in the public parks of a number of cities [312]. In the Netherlands, particularly in Amsterdam, wastewater is regarded as a rich resource of organic matter, including alginic acid, cellulose, bioplastic, biogas, and phosphorus obtainment, that can be recovered and reused [313]. Moreover, wastewater reuse has converted Singapore into a universal hydro-hub via the implementation of novel water technologies that allowed the nation to meet $30 \%$ of its water demands, a number that is 
set to increase to $55 \%$ by 2060 [314]. Wastewater reuse usually demands higher standards of treatment, since it may well contain higher pathogen content than greywater [315]. Greywater reuse is, therefore, much easier when separated from wastewater [316]. However, water contamination is possible in all pathways to an extent that necessitates adequate safety measures prior to the establishment of new systems. In this regard, Singapore has approved a potential multi-phase approach to water reuse, involving primary sedimentation, followed by activated sludge and microfiltration, and then ultrafiltration, reverse osmosis and, eventually, disinfection by ultraviolet radiation exposure [314]. This approach can also be highly beneficial to eliminate or significantly reduce public health risks associated with the reuse of various wastewater streams. However, the targets should be well defined and technical solutions and proper assessment tools should be made available to ensure that it meets the recommended guidelines of safe water reuse.

Technical solutions for reuse of treated water includes: (i) the employment of innovative tools and technologies, such as the replacement of old equipment used for water treatment with new technologies, including membrane bioreactor (MBR)-based treatment [317,318], (ii) the establishment of an evaluation approach for determining water cost, that is energetic and equivalence-dependent, alongside treatment strategies [319], and (iii) solving the gap between water supply and water demand via desalination methodologies [320,321], control of runoff water [322], wastewater reuse [323], and cloud seeding [324]. However, the technical solution selection mandates the inclusion of a short costs analysis that depends on the nature of water reuse projects being chargeable or not [325]. For instance, regenerated water use for industrial purposes or course irrigation in the private sector required investment costs that reached AUD $>3 / \mathrm{m}^{3}$ in Australia [326] and up to EUR $736 / \mathrm{m}^{3}$ produced/day in Spain, with an additional EUR $0.06 / \mathrm{m}^{3}$ to EUR $0.45 / \mathrm{m}^{3}$ for operational costs that varied according to the regenerated water uses and the required treatment [327]. On the contrary, regenerated water for water resources restoration and maintenance, the recharging of aquifers, or reduction of treated effluent discharge into essential water bodies is not chargeable $[325,328]$. Technical solutions for water reuse should be assessed for, in particular, viral load reduction efficacy to avoid any associated health concerns due to direct exposure. The MBR treatment process was found to be of higher efficiency, in terms of both bacterial and virus removals, than the activated sludge process, which results in up to $2 \log _{10}$ bacterial load reduction and lacks virus removal capability [329]. For example, adenoviruses and enteroviruses, and even infectious enteroviruses, were 3.7, 1.7 , and $2 \log _{10}$ reduced, respectively, following MBR-based treatment in Saudi Arabia [318].

Nevertheless, such efforts for the reuse of treated water, alongside the offered technical solutions, were opposed by serious limitations raised against irrigation using treated water. The alteration of the texture properties and physicochemical parameters of soil, due to agricultural reuse, led to changed microbiota and biomass [29]. Moreover, probable modifications of soil microbiota could influence soil fertility and subsequent productivity [21]. In addition, organic matter mineralization [330] and nutrients and metals availability [331,332] were affected by altered soil $\mathrm{pH}$ caused by irrigation with WWTP effluents. Therefore, reuse of insufficiently treated wastewater, or even raw water, could serve as alternative sources for irrigation, avoiding these risk factors [29]. However, other risk factors may emerge from the high burden of enteric pathogens. The norovirus disease burden due to the consumption of lettuce irrigated with untreated greywater was assessed by QMRA model and revealed an annual disease burden fluctuation above the range of $2 \times 10^{-8}$ and $5 \times 10^{-4}$ [333].

On the other hand, wastewater reuse is commonly practiced for potable purposes owing to the incidental presence of treated wastewater in a water supply source, termed de facto wastewater reuse. Upstream WWTP discharge was reported by the EPA as influencing drinking water treatment plants (DWTPs), which included 2-16\% of upstream wastewater discharges [334]. For instance, DWTPs, containing 50\% upstream WWTP discharges, were used to serve over $10^{4}$ U.S. people, as reported in [335]. However, extensive risk assessment 
studies were concerned with the associated risks due to de facto reuse $[30,336,337]$ and an annual risk of $>1$ infection $/ 10^{5}$ people was recorded [338]. Moreover, the median norovirus risk per year was the highest in the case of de facto reuse, when compared to other treatment scenarios, to such an extent that de facto reuse scenarios exceeded risk benchmarks $\left(10^{-\mathrm{o}}\right)$. Alarmingly, $1 \%$ wastewater effluent was predicted to potentially surge drinking water risks if contributed to the source water [30]. De facto reuse is still applicable globally and de facto reuse is expected to increase in the future due to an increased frequency of water supplies shortages and droughts [339].

The Water Safety Plan (WSP) is receiving increasing attention as a recommended risk management approach for water reuse. The establishment of the WSP approach organized drinking-water-related management practices and assured the applicability of these practices to drinking-water quality management. A WSP encompasses, at least, a system assessment and effective operational monitoring and management to ensure drinking-water safety. Moreover, a WSP integrates various principles of other risk management approaches including, of a particular interest, the multiple-barrier approach and HACCP [340]. HACCP development presented an earlier framework for the improvement of drinking water treatment processes to minimize the probability of waterborne disease incidence [341]. Moreover, repairing and maintaining the drinking water distribution network was highlighted as a means of preventing drinking water contamination. In this regard, the necessity of HACCP implementation was reported in terms of avoiding microbial contamination incidence in drinking water treatment lines [342].

\section{Conclusions}

The high persistence of enteric viruses in various water environments enabled their detection in almost all water sources with a significantly higher frequency. However, detection frequency of enteric viruses could vary according to the virus type, geographical location, water source, and the assigned period for sampling, irrelevant to virus concentration. Second, virus detection is not usually associated with virus infectivity, wherein the presence of infectious virus particles indicate infectivity and the resultant infection risk. Moreover, infection risk relies on detection specificity since the virus origin, whether of human origin or not, could determine the course of infection. For example, the RDRP gene of SARS-CoV-2 was found to be of higher specificity than other genes. On the other hand, exposure to wastewater discharge should be monitored and controlled for probable health issues. Consequently, a toolbox approach, implementing both pepper mild mottle virus and cross-assembly phage together, was highly encouraged for the traceability of any possible fecal pollution. Moreover, MBR-based treatment for wastewater reuse was much more efficient in both bacterial and viral burden reduction than activated sludge, which cannot achieve virus removal. A WSP could likewise help in the quality management of de facto wastewater reuse through the employment of HACCP throughout the wastewater treatment strategies. This review article provided the information necessary for decision making in terms of determining the most probable viral etiologies as well as evaluating the resultant risks associated with direct or indirect exposure to both discharged or reused wastewater.

Author Contributions: Conceptualization, I.N., A.H., M.R. and S.E.; writing-original draft preparation, I.N.; writing-review and editing, I.N., A.H., M.R and S.E.; visualization, I.N.; funding acquisition, A.H. All authors have read and agreed to the published version of the manuscript.

Funding: This research was funded by Deanship of Scientific Research at King Saud University, grant number RG-1441-492.

Institutional Review Board Statement: Not applicable.

Informed Consent Statement: Not applicable.

Acknowledgments: The authors extend their gratitude to the Deanship of Scientific Research at King Saud University for funding this work through research group (no. RG-1441-492). 
Conflicts of Interest: The authors declare no conflict of interest.

\section{References}

1. Carding, S.R.; Davis, N.; Hoyles, L. The Human Intestinal Virome in Health and Disease. Aliment. Pharmacol. Ther. 2017, 46, 800-815. [CrossRef]

2. $\quad$ Lim, E.S.; Zhou, Y.; Zhao, G.; Bauer, I.K.; Droit, L.; Ndao, I.M.; Warner, B.B.; Tarr, P.I.; Wang, D.; Holtz, L.R. Early Life Dynamics of the Human Gut Virome and Bacterial Microbiome in Infants. Nat. Med. 2015, 21, 1228. [CrossRef] [PubMed]

3. Schloss, P.D.; Schubert, A.M.; Zackular, J.P.; Iverson, K.D.; Young, V.B.; Petrosino, J.F. Stabilization of the Murine Gut Microbiome Following Weaning. Gut Microbes 2012, 3, 383-393. [CrossRef] [PubMed]

4. Maqsood, R.; Rodgers, R.; Rodriguez, C.; Handley, S.A.; Ndao, I.M.; Tarr, P.I.; Warner, B.B.; Lim, E.S.; Holtz, L.R. Discordant Transmission of Bacteria and Viruses from Mothers to Babies at Birth. Microbiome 2019, 7, 1-13. [CrossRef]

5. Minot, S.; Bryson, A.; Chehoud, C.; Wu, G.D.; Lewis, J.D.; Bushman, F.D. Rapid Evolution of the Human Gut Virome. Proc. Natl. Acad. Sci. USA 2013, 110, 12450-12455. [CrossRef]

6. Lawrence, R.M. Transmission of infectious diseases through breast milk and breastfeeding. In Breastfeeding; Elsevier: Amsterdam, The Netherlands, 2022; pp. 393-456.

7. Khuroo, M.S.; Khuroo, M.S.; Khuroo, N.S. Transmission of Hepatitis E Virus in Developing Countries. Viruses 2016, 8, 253. [CrossRef] [PubMed]

8. Khuroo, M.S.; Kamili, S.; Khuroo, M.S. Clinical Course and Duration of Viremia in Vertically Transmitted Hepatitis E Virus (HEV) Infection in Babies Born to HEV-Infected Mothers. J. Viral Hepat. 2009, 16, 519-523. [CrossRef] [PubMed]

9. Grimwood, K.; Lambert, S.B.; Milne, R.J. Rotavirus Infections and Vaccines. Pediatr. Drugs 2010, 12, 235-256. [CrossRef] [PubMed]

10. Shrestha, S.K.; Shrestha, J.; Andreassen, A.K.; Strand, T.A.; Dudman, S.; Dembinski, J.L. Genetic Diversity of Astrovirus in Children from a Birth Cohort in Nepal. Front. Microbiol. 2021, 11, 3537. [CrossRef]

11. Armbrust, S.; Kramer, A.; Olbertz, D.; Zimmermann, K.; Fusch, C. Norovirus Infections in Preterm Infants: Wide Variety of Clinical Courses. BMC Res. Notes 2009, 2,1-6. [CrossRef]

12. Elnifro, E.M.; Cooper, R.J.; Dady, I.; Hany, S.; Mughal, Z.M.; Klapper, P.E. Three Nonfatal Cases of Neonatal Adenovirus Infection. J. Clin. Microbiol. 2005, 43, 5814-5815. [CrossRef]

13. Seitz, S.R.; Leon, J.S.; Schwab, K.J.; Lyon, G.M.; Dowd, M.; McDaniels, M.; Abdulhafid, G.; Fernandez, M.L.; Lindesmith, L.C.; Baric, R.S. Norovirus Infectivity in Humans and Persistence in Water. Appl. Environ. Microbiol. 2011, 77, 6884-6888. [CrossRef]

14. Ogorzaly, L.; Bertrand, I.; Paris, M.; Maul, A.; Gantzer, C. Occurrence, Survival, and Persistence of Human Adenoviruses and F-Specific RNA Phages in Raw Groundwater. Appl. Environ. Microbiol. 2010, 76, 8019-8025. [CrossRef] [PubMed]

15. Rzeżutka, A.; Cook, N. Survival of Human Enteric Viruses in the Environment and Food. FEMS Microbiol. Rev. 2004, 28, 441-453. [CrossRef] [PubMed]

16. Raphael, R.A.; Sattar, S.A.; Springthorpe, V.S. Long-Term Survival of Human Rotavirus in Raw and Treated River Water. Can. J. Microbiol. 1985, 31, 124-128. [CrossRef] [PubMed]

17. Gorgich, M.; Mata, T.M.; Martins, A.; Caetano, N.S.; Formigo, N. Application of Domestic Greywater for Irrigating Agricultural Products: A Brief Study. Energy Rep. 2020, 6, 811-817. [CrossRef]

18. Angelakis, A.N.; Asano, T.; Bahri, A.; Jimenez, B.E.; Tchobanoglous, G. Water Reuse: From Ancient to Modern Times and the Future. Front. Environ. Sci. 2018, 6, 26. [CrossRef]

19. Libutti, A.; Gatta, G.; Gagliardi, A.; Vergine, P.; Pollice, A.; Beneduce, L.; Disciglio, G.; Tarantino, E. Agro-Industrial Wastewater Reuse for Irrigation of a Vegetable Crop Succession under Mediterranean Conditions. Agric. Water Manag. 2018, 196, 1-14. [CrossRef]

20. Fountoulakis, M.S.; Markakis, N.; Petousi, I.; Manios, T. Single House On-Site Grey Water Treatment Using a Submerged Membrane Bioreactor for Toilet Flushing. Sci. Total Environ. 2016, 551, 706-711. [CrossRef]

21. Becerra-Castro, C.; Lopes, A.R.; Vaz-Moreira, I.; Silva, E.F.; Manaia, C.M.; Nunes, O.C. Wastewater Reuse in Irrigation: A Microbiological Perspective on Implications in Soil Fertility and Human and Environmental Health. Environ. Int. 2015, 75, 117-135. [CrossRef]

22. Nour, I.; Hanif, A.; Alanazi, I.O.; Al-Ashkar, I.; Alhetheel, A.; Eifan, S. Novel Insights of Waterborne Human Rotavirus A in Riyadh (Saudi Arabia) Involving G2 Predominance and Emergence of a Thermotolerant Sequence. Sci. Rep. 2021, 11, 1-12. [CrossRef] [PubMed]

23. Bisseux, M.; Colombet, J.; Mirand, A.; Roque-Afonso, A.-M.; Abravanel, F.; Izopet, J.; Archimbaud, C.; Peigue-Lafeuille, H.; Debroas, D.; Bailly, J.-L. Monitoring Human Enteric Viruses in Wastewater and Relevance to Infections Encountered in the Clinical Setting: A One-Year Experiment in Central France, 2014 to 2015. Eurosurveillance 2018, 23, 17-00237. [CrossRef] [PubMed]

24. Chaudhry, A.K.; Sachdeva, P. Coronavirus Disease 2019 (COVID-19): A New Challenge in Untreated Wastewater. Can. J. Civ. Eng. 2020, 47, 1005-1009. [CrossRef]

25. Tran, H.N.; Le, G.T.; Nguyen, D.T.; Juang, R.-S.; Rinklebe, J.; Bhatnagar, A.; Lima, E.C.; Iqbal, H.M.; Sarmah, A.K.; Chao, H.-P. SARS-CoV-2 Coronavirus in Water and Wastewater: A Critical Review about Presence and Concern. Environ. Res. 2020, 110265. [CrossRef] [PubMed]

26. Bivins, A.; Greaves, J.; Fischer, R.; Yinda, K.C.; Ahmed, W.; Kitajima, M.; Munster, V.J.; Bibby, K. Persistence of SARS-CoV-2 in Water and Wastewater. Environ. Sci. Technol. Lett. 2020, 7, 937-942. [CrossRef] 
27. Van Tung, T.; Tran, Q.B.; Thao, N.T.P.; Hieu, T.T.; Le, S.; Tuan, N.Q.; Sonne, C.; Lam, S.S.; Van Le, Q. Recycling of Aquaculture Wastewater and Sediment for Sustainable Corn and Water Spinach Production. Chemosphere 2021, 268, 129329. [CrossRef]

28. Garcia, X.; Pargament, D. Reusing Wastewater to Cope with Water Scarcity: Economic, Social and Environmental Considerations for Decision-Making. Resour. Conserv. Recycl. 2015, 101, 154-166. [CrossRef]

29. Jaramillo, M.F.; Restrepo, I. Wastewater Reuse in Agriculture: A Review about Its Limitations and Benefits. Sustainability 2017, 9 , 1734. [CrossRef]

30. Chaudhry, R.M.; Hamilton, K.A.; Haas, C.N.; Nelson, K.L. Drivers of Microbial Risk for Direct Potable Reuse and de Facto Reuse Treatment Schemes: The Impacts of Source Water Quality and Blending. Int. J. Environ. Res. Public Health 2017, 14, 635. [CrossRef]

31. Aagaard, K.; Ma, J.; Antony, K.M.; Ganu, R.; Petrosino, J.; Versalovic, J. The Placenta Harbors a Unique Microbiome. Sci. Transl. Med. 2014, 6, 237ra65. [CrossRef]

32. Bergström, A.; Skov, T.H.; Bahl, M.I.; Roager, H.M.; Christensen, L.B.; Ejlerskov, K.T.; Mølgaard, C.; Michaelsen, K.F.; Licht, T.R. Establishment of Intestinal Microbiota during Early Life: A Longitudinal, Explorative Study of a Large Cohort of Danish Infants. Appl. Environ. Microbiol. 2014, 80, 2889. [CrossRef]

33. Matamoros, S.; Gras-Leguen, C.; Le Vacon, F.; Potel, G.; de La Cochetiere, M.-F. Development of Intestinal Microbiota in Infants and Its Impact on Health. Trends Microbiol. 2013, 21, 167-173. [CrossRef]

34. Penders, J.; Thijs, C.; Vink, C.; Stelma, F.F.; Snijders, B.; Kummeling, I.; van den Brandt, P.A.; Stobberingh, E.E. Factors Influencing the Composition of the Intestinal Microbiota in Early Infancy. Pediatrics 2006, 118, 511-521. [CrossRef] [PubMed]

35. Hill, C.J.; Lynch, D.B.; Murphy, K.; Ulaszewska, M.; Jeffery, I.B.; O’Shea, C.A.; Watkins, C.; Dempsey, E.; Mattivi, F.; Tuohy, K. Evolution of Gut Microbiota Composition from Birth to 24 Weeks in the INFANTMET Cohort. Microbiome 2017, 5, 1-18. [CrossRef] [PubMed]

36. Milani, C.; Duranti, S.; Bottacini, F.; Casey, E.; Turroni, F.; Mahony, J.; Belzer, C.; Palacio, S.D.; Montes, S.A.; Mancabelli, L. The First Microbial Colonizers of the Human Gut: Composition, Activities, and Health Implications of the Infant Gut Microbiota. Microbiol. Mol. Biol. Rev. MMBR 2017, 81. [CrossRef] [PubMed]

37. Rodríguez, J.M.; Murphy, K.; Stanton, C.; Ross, R.P.; Kober, O.I.; Juge, N.; Avershina, E.; Rudi, K.; Narbad, A.; Jenmalm, M.C. The Composition of the Gut Microbiota throughout Life, with an Emphasis on Early Life. Microb. Ecol. Health Dis. 2015, $26,26050$. [CrossRef]

38. McCann, A.; Ryan, F.J.; Stockdale, S.R.; Dalmasso, M.; Blake, T.; Ryan, C.A.; Stanton, C.; Mills, S.; Ross, P.R.; Hill, C. Viromes of One Year Old Infants Reveal the Impact of Birth Mode on Microbiome Diversity. PeerJ 2018, 6, e4694. [CrossRef]

39. Kurokawa, K.; Itoh, T.; Kuwahara, T.; Oshima, K.; Toh, H.; Toyoda, A.; Takami, H.; Morita, H.; Sharma, V.K.; Srivastava, T.P. Comparative Metagenomics Revealed Commonly Enriched Gene Sets in Human Gut Microbiomes. Dna Res. 2007, 14, 169-181. [CrossRef]

40. Mueller, N.T.; Bakacs, E.; Combellick, J.; Grigoryan, Z.; Dominguez-Bello, M.G. The Infant Microbiome Development: Mom Matters. Trends Mol. Med. 2015, 21, 109-117. [CrossRef]

41. Goedert, J.J.; Hua, X.; Yu, G.; Shi, J. Diversity and Composition of the Adult Fecal Microbiome Associated with History of Cesarean Birth or Appendectomy: Analysis of the American Gut Project. EBioMedicine 2014, 1, 167-172. [CrossRef]

42. Zhou, P.; Zhou, Y.; Liu, B.; Jin, Z.; Zhuang, X.; Dai, W.; Yang, Z.; Feng, X.; Zhou, Q.; Liu, Y. Perinatal Antibiotic Exposure Affects the Transmission between Maternal and Neonatal Microbiota and Is Associated with Early-Onset Sepsis. Msphere 2020, 5. [CrossRef] [PubMed]

43. Modi, S.R.; Lee, H.H.; Spina, C.S.; Collins, J.J. Antibiotic Treatment Expands the Resistance Reservoir and Ecological Network of the Phage Metagenome. Nature 2013, 499, 219-222. [CrossRef] [PubMed]

44. Allen, H.K.; Looft, T.; Bayles, D.O.; Humphrey, S.; Levine, U.Y.; Alt, D.; Stanton, T.B. Antibiotics in Feed Induce Prophages in Swine Fecal Microbiomes. MBio 2011, 2. [CrossRef] [PubMed]

45. Sommer, M.O.; Dantas, G. Antibiotics and the Resistant Microbiome. Curr. Opin. Microbiol. 2011, 14, 556-563. [CrossRef] [PubMed]

46. Norman, J.M.; Handley, S.A.; Baldridge, M.T.; Droit, L.; Liu, C.Y.; Keller, B.C.; Kambal, A.; Monaco, C.L.; Zhao, G.; Fleshner, P. Disease-Specific Alterations in the Enteric Virome in Inflammatory Bowel Disease. Cell 2015, 160, 447-460. [CrossRef] [PubMed]

47. Schwartz, S.; Friedberg, I.; Ivanov, I.V.; Davidson, L.A.; Goldsby, J.S.; Dahl, D.B.; Herman, D.; Wang, M.; Donovan, S.M.; Chapkin, R.S. A Metagenomic Study of Diet-Dependent Interaction between Gut Microbiota and Host in Infants Reveals Differences in Immune Response. Genome Biol. 2012, 13, 1-16. [CrossRef] [PubMed]

48. Tremaroli, V.; Bäckhed, F. Functional Interactions between the Gut Microbiota and Host Metabolism. Nature 2012, 489, 242-249. [CrossRef]

49. Kinross, J.M.; Darzi, A.W.; Nicholson, J.K. Gut Microbiome-Host Interactions in Health and Disease. Genome Med. 2011 , 3, 1-12. [CrossRef]

50. Reyes, A.; Blanton, L.V.; Cao, S.; Zhao, G.; Manary, M.; Trehan, I.; Smith, M.I.; Wang, D.; Virgin, H.W.; Rohwer, F. Gut DNA Viromes of Malawian Twins Discordant for Severe Acute Malnutrition. Proc. Natl. Acad. Sci. USA 2015, 112, 11941-11946. [CrossRef]

51. Breitbart, M.; Haynes, M.; Kelley, S.; Angly, F.; Edwards, R.A.; Felts, B.; Mahaffy, J.M.; Mueller, J.; Nulton, J.; Rayhawk, S. Viral Diversity and Dynamics in an Infant Gut. Res. Microbiol. 2008, 159, 367-373. [CrossRef] 
52. Mukhopadhya, I.; Segal, J.P.; Carding, S.R.; Hart, A.L.; Hold, G.L. The Gut Virome: The ‘Missing Link'between Gut Bacteria and Host Immunity? Ther. Adv. Gastroenterol. 2019, 12, 1756284819836620. [CrossRef] [PubMed]

53. Baschat, A.A.; Towbin, J.; Bowles, N.E.; Harman, C.R.; Weiner, C.P. Prevalence of Viral DNA in Amniotic Fluid of Low-Risk Pregnancies in the Second Trimester. J. Matern. Fetal Neonatal Med. 2003, 13, 381-384. [CrossRef] [PubMed]

54. Lim, E.S.; Wang, D.; Holtz, L.R. The Bacterial Microbiome and Virome Milestones of Infant Development. Trends Microbiol. 2016, 24, 801-810. [CrossRef] [PubMed]

55. Watson, J.C.; Fleming, D.W.; Borella, A.J.; Olcott, E.S.; Conrad, R.E.; Baron, R.C. Vertical Transmission of Hepatitis A Resulting in an Outbreak in a Neonatal Intensive Care Unit. J. Infect. Dis. 1993, 167, 567-571. [CrossRef]

56. Ciccarelli, S.; Stolfi, I.; Caramia, G. Management Strategies in the Treatment of Neonatal and Pediatric Gastroenteritis. Infect. Drug Resist. 2013, 6, 133.

57. Opere, W.M.; John, M.; Ombori, O. Molecular Detection of Human Enteric Adenoviruses in Water Samples Collected from Lake Victoria Waters Along Homa Bay Town, Homa Bay County, Kenya. Food Environ. Virol. 2021, 13, 32-43. [CrossRef]

58. Dhingra, A.; Hage, E.; Ganzenmueller, T.; Böttcher, S.; Hofmann, J.; Hamprecht, K.; Obermeier, P.; Rath, B.; Hausmann, F.; Dobner, T. Molecular Evolution of Human Adenovirus (HAdV) Species C. Sci. Rep. 2019, 9, 1-13. [CrossRef]

59. Hashimoto, S.; Gonzalez, G.; Harada, S.; Oosako, H.; Hanaoka, N.; Hinokuma, R.; Fujimoto, T. Recombinant Type Human Mastadenovirus D85 Associated with Epidemic Keratoconjunctivitis since 2015 in Japan. J. Med Virol. 2018, 90, 881-889. [CrossRef]

60. Robinson, C.M.; Singh, G.; Lee, J.Y.; Dehghan, S.; Rajaiya, J.; Liu, E.B.; Yousuf, M.A.; Betensky, R.A.; Jones, M.S.; Dyer, D.W. Molecular Evolution of Human Adenoviruses. Sci. Rep. 2013, 3, 1-7. [CrossRef] [PubMed]

61. Seto, D.; Chodosh, J.; Brister, J.R.; Jones, M.S.; Community, A.R. Using the Whole-Genome Sequence to Characterize and Name Human Adenoviruses. J. Virol. 2011, 85, 5701. [CrossRef] [PubMed]

62. Eckardt, A.J.; Baumgart, D.C. Viral Gastroenteritis in Adults. Recent Pat. Antiinfect. Drug Discov. 2011, 6, 54-63. [CrossRef] [PubMed]

63. Centers for Disease Control and Prevention. CDC Acute Respiratory Disease Associated with Adenovirus Serotype 14-Four States, 2006-2007. MMWR. Morb. Mortal. Wkly. Rep. 2007, 56, 1181-1184.

64. Elmahdy, E.M.; Shaheen, M.N.; Rizk, N.M.; Saad-Hussein, A. Quantitative Detection of Human Adenovirus and Human Rotavirus Group A in Wastewater and El-Rahawy Drainage Canal Influencing River Nile in the North of Giza, Egypt. Food Environ. Virol. 2020, 12, 218-225. [CrossRef] [PubMed]

65. Farkas, K.; Marshall, M.; Cooper, D.; McDonald, J.E.; Malham, S.K.; Peters, D.E.; Maloney, J.D.; Jones, D.L. Seasonal and Diurnal Surveillance of Treated and Untreated Wastewater for Human Enteric Viruses. Environ. Sci. Pollut. Res. 2018, 25, 33391-33401. [CrossRef] [PubMed]

66. Fong, T.-T.; Phanikumar, M.S.; Xagoraraki, I.; Rose, J.B. Quantitative Detection of Human Adenoviruses in Wastewater and Combined Sewer Overflows Influencing a Michigan River. Appl. Environ. Microbiol. 2010, 76, 715-723. [CrossRef] [PubMed]

67. Sidhu, J.P.; Ahmed, W.; Palmer, A.; Smith, K.; Hodgers, L.; Toze, S. Optimization of Sampling Strategy to Determine Pathogen Removal Efficacy of Activated Sludge Treatment Plant. Environ. Sci. Pollut. Res. 2017, 24, 19001-19010. [CrossRef] [PubMed]

68. Lin, J.; Ganesh, A. Water Quality Indicators: Bacteria, Coliphages, Enteric Viruses. Int. J. Environ. Health Res. 2013, 23, 484-506. [CrossRef]

69. Eischeid, A.C.; Meyer, J.N.; Linden, K.G. UV Disinfection of Adenoviruses: Molecular Indications of DNA Damage Efficiency. Appl. Environ. Microbiol. 2009, 75, 23. [CrossRef]

70. Brestovitsky, A.; Nebenzahl-Sharon, K.; Kechker, P.; Sharf, R.; Kleinberger, T. The Adenovirus E4orf4 Protein Provides a Novel Mechanism for Inhibition of the DNA Damage Response. PLoS Pathog. 2016, 12, e1005420. [CrossRef] [PubMed]

71. Silva, H.D.; García-Zapata, M.T.; Anunciação, C.E. Why the Use of Adenoviruses as Water Quality Virologic Marker? Food Environ. Virol. 2011, 3, 138-140. [CrossRef]

72. Nour, I.; Hanif, A.; Zakri, A.M.; Al-Ashkar, I.; Alhetheel, A.; Eifan, S. Human Adenovirus Molecular Characterization in Various Water Environments and Seasonal Impacts in Riyadh, Saudi Arabia. Int. J. Environ. Res. Public Health 2021, 18, 4773. [CrossRef]

73. Elmahdy, E.M.; Ahmed, N.I.; Shaheen, M.N.; Mohamed, E.-C.B.; Loutfy, S.A. Molecular Detection of Human Adenovirus in Urban Wastewater in Egypt and among Children Suffering from Acute Gastroenteritis. J. Water Health 2019, 17, 287-294. [CrossRef]

74. Shaheen, M.N.; Elmahdy, E.M.; Chawla-Sarkar, M. Quantitative PCR-Based Identification of Enteric Viruses Contaminating Fresh Produce and Surface Water Used for Irrigation in Egypt. Environ. Sci. Pollut. Res. 2019, 26, 21619-21628. [CrossRef] [PubMed]

75. Katayama, H.; Haramoto, E.; Oguma, K.; Yamashita, H.; Tajima, A.; Nakajima, H.; Ohgaki, S. One-Year Monthly Quantitative Survey of Noroviruses, Enteroviruses, and Adenoviruses in Wastewater Collected from Six Plants in Japan. Water Res. 2008, 42, 1441-1448. [CrossRef] [PubMed]

76. Sdiri-Loulizi, K.; Hassine, M.; Aouni, Z.; Gharbi-Khelifi, H.; Chouchane, S.; Sakly, N.; Neji-Guédiche, M.; Pothier, P.; Aouni, M.; Ambert-Balay, K. Detection and Molecular Characterization of Enteric Viruses in Environmental Samples in Monastir, Tunisia between January 2003 and April 2007. J. Appl. Microbiol. 2010, 109, 1093-1104. [CrossRef] [PubMed]

77. Bortagaray, V.; Lizasoain, A.; Piccini, C.; Gillman, L.; Berois, M.; Pou, S.; del Pilar Díaz, M.; Tort, F.L.; Colina, R.; Victoria, M. Microbial Source Tracking Analysis Using Viral Indicators in Santa Lucía and Uruguay Rivers, Uruguay. Food Environ. Virol. 2019, 11, 259-267. [CrossRef] [PubMed] 
78. Gamazo, P.; Victoria, M.; Schijven, J.F.; Alvareda, E.; Tort, L.F.L.; Ramos, J.; Burutaran, L.; Olivera, M.; Lizasoain, A.; Sapriza, G. Evaluation of Bacterial Contamination as an Indicator of Viral Contamination in a Sedimentary Aquifer in Uruguay. Food Environ. Virol. 2018, 10, 305-315. [CrossRef] [PubMed]

79. Sibanda, T.; Okoh, A.I. Assessment of the Incidence of Enteric Adenovirus Species and Serotypes in Surface Waters in the Eastern Cape Province of South Africa: Tyume River as a Case Study. Sci. World J. 2012, 2012. [CrossRef] [PubMed]

80. Osuolale, O.; Okoh, A. Incidence of Human Adenoviruses and Hepatitis A Virus in the Final Effluent of Selected Wastewater Treatment Plants in Eastern Cape Province, South Africa. Virol. J. 2015, 12, 1-8. [CrossRef]

81. Rashid, M.; Khan, M.N.; Jalbani, N. Detection of Human Adenovirus, Rotavirus, and Enterovirus in Tap Water and Their Association with the Overall Quality of Water in Karachi, Pakistan. Food Env. Virol 2021, 13, 44-52. [CrossRef]

82. Symonds, E.M.; Griffin, D.W.; Breitbart, M. Eukaryotic Viruses in Wastewater Samples from the United States. Appl. Environ. Microbiol. 2009, 75, 1402-1409. [CrossRef]

83. Staggemeier, R.; Heck, T.M.; Demoliner, M.; Ritzel, R.G.; Röhnelt, N.M.; Girardi, V.; Venker, C.A.; Spilki, F.R. Enteric Viruses and Adenovirus Diversity in Waters from 2016 Olympic Venues. Sci. Total. Environ. 2017, 586, 304-312. [CrossRef] [PubMed]

84. La Rosa, G.; Pourshaban, M.; Iaconelli, M.; Muscillo, M. Quantitative Real-Time PCR of Enteric Viruses in Influent and Effluent Samples from Wastewater Treatment Plants in Italy. Ann. Ist. Super. Sanita 2010, 46, 266-273. [PubMed]

85. Iaconelli, M.; Valdazo-González, B.; Equestre, M.; Ciccaglione, A.R.; Marcantonio, C.; Della Libera, S.; La Rosa, G. Molecular Characterization of Human Adenoviruses in Urban Wastewaters Using next Generation and Sanger Sequencing. Water Res. 2017, 121, 240-247. [CrossRef] [PubMed]

86. Farkas, K.; Cooper, D.M.; McDonald, J.E.; Malham, S.K.; de Rougemont, A.; Jones, D.L. Seasonal and Spatial Dynamics of Enteric Viruses in Wastewater and in Riverine and Estuarine Receiving Waters. Sci. Total. Environ. 2018, 634, 1174-1183. [CrossRef] [PubMed]

87. Schijven, J.; Teunis, P.; Suylen, T.; Ketelaars, H.; Hornstra, L.; Rutjes, S. QMRA of Adenovirus in Drinking Water at a Drinking Water Treatment Plant Using UV and Chlorine Dioxide Disinfection. Water Res. 2019, 158, 34-45. [CrossRef]

88. Li, J.; Lu, X.; Sun, Y.; Lin, C.; Li, F.; Yang, Y.; Liang, Z.; Jia, L.; Chen, L.; Jiang, B. A Swimming Pool-Associated Outbreak of Pharyngoconjunctival Fever Caused by Human Adenovirus Type 4 in Beijing, China. Int. J. Infect. Dis. 2018, 75, 89-91. [CrossRef]

89. Pang, X.; Qiu, Y.; Gao, T.; Zurawell, R.; Neumann, N.F.; Craik, S.; Lee, B.E. Prevalence, Levels and Seasonal Variations of Human Enteric Viruses in Six Major Rivers in Alberta, Canada. Water Res. 2019, 153, 349-356. [CrossRef] [PubMed]

90. Sedji, M.I.; Varbanov, M.; Meo, M.; Colin, M.; Mathieu, L.; Bertrand, I. Quantification of Human Adenovirus and Norovirus in River Water in the North-East of France. Environ. Sci. Pollut. Res. 2018, 25, 30497-30507. [CrossRef]

91. Wang, H.; Sikora, P.; Rutgersson, C.; Lindh, M.; Brodin, T.; Björlenius, B.; Larsson, D.J.; Norder, H. Differential Removal of Human Pathogenic Viruses from Sewage by Conventional and Ozone Treatments. Int. J. Hyg. Environ. Health 2018, 221, 479-488. [CrossRef]

92. Hellmér, M.; Paxéus, N.; Magnius, L.; Enache, L.; Arnholm, B.; Johansson, A.; Bergström, T.; Norder, H. Detection of Pathogenic Viruses in Sewage Provided Early Warnings of Hepatitis A Virus and Norovirus Outbreaks. Appl. Environ. Microbiol. 2014, 80, 6771-6781. [CrossRef]

93. McDonald, S.M.; Patton, J.T. Assortment and Packaging of the Segmented Rotavirus Genome. Trends Microbiol. 2011, 19, 136-144. [CrossRef]

94. Lee, R.M.; Lessler, J.; Lee, R.A.; Rudolph, K.E.; Reich, N.G.; Perl, T.M.; Cummings, D.A. Incubation Periods of Viral Gastroenteritis: A Systematic Review. BMC Infect. Dis. 2013, 13, 1-11. [CrossRef]

95. Kirkwood, C.D. Genetic and Antigenic Diversity of Human Rotaviruses: Potential Impact on Vaccination Programs. J. Infect. Dis. 2010, 202, S43-S48. [CrossRef]

96. Giri, S.; Nair, N.P.; Mathew, A.; Manohar, B.; Simon, A.; Singh, T.; Kumar, S.S.; Mathew, M.A.; Babji, S.; Arora, R. Rotavirus Gastroenteritis in Indian Children <5 Years Hospitalized for Diarrhoea, 2012 to 2016. BMC Public Health 2019, 19, 1-10.

97. Phan, T.; Ide, T.; Komoto, S.; Khamrin, P.; Pham, N.T.K.; Okitsu, S.; Taniguchi, K.; Nishimura, S.; Maneekarn, N.; Hayakawa, S. Genomic Analysis of Group A Rotavirus G12P [8] Including a New Japanese Strain Revealed Evidence for Intergenotypic Recombination in VP7 and VP4 Genes. Infect. Genet. Evol. 2021, 87, 104656. [CrossRef] [PubMed]

98. Sai, L.; Sun, J.; Shao, L.; Chen, S.; Liu, H.; Ma, L. Epidemiology and Clinical Features of Rotavirus and Norovirus Infection among Children in Ji'nan, China. Virol. J. 2013, 10, 1-8. [CrossRef] [PubMed]

99. Bresee, J.S.; Glass, R.I.; Ivanoff, B.; Gentsch, J.R. Current Status and Future Priorities for Rotavirus Vaccine Development, Evaluation and Implementation in Developing Countries. Vaccine 1999, 17, 2207-2222. [CrossRef]

100. Alidjinou, E.K.; Sane, F.; Firquet, S.; Lobert, P.-E.; Hober, D. Resistance of Enteric Viruses on Fomites. Intervirology 2018, 61, 205-213. [CrossRef] [PubMed]

101. Desselberger, U. Rotaviruses. Virus research 2014, 190, 75-96. [CrossRef]

102. Estes, M.K.; Graham, D.Y.; Smith, E.M.; Gerba, C.P. Rotavirus Stability and Inactivation. J. Gen. Virol. 1979, 43, 403-409. [CrossRef] [PubMed]

103. Pinon, A.; Vialette, M. Survival of Viruses in Water. Intervirology 2018, 61, 214-222. [CrossRef] [PubMed]

104. Meng, Z.D.; Birch, C.; Heath, R.; Gust, I. Physicochemical Stability and Inactivation of Human and Simian Rotaviruses. Appl. Environ. Microbiol. 1987, 53, 727-730. [CrossRef] [PubMed] 
105. Bortagaray, V.; Girardi, V.; Pou, S.; Lizasoain, A.; Tort, L.F.L.; Spilki, F.R.; Colina, R.; Victoria, M. Detection, Quantification, and Microbial Risk Assessment of Group A Rotavirus in Rivers from Uruguay. Food Environ. Virol. 2020, 12, 89-98. [CrossRef] [PubMed]

106. Jain, P.; Jain, A. Waterborne viral gastroenteritis: An introduction to common agents. In Water and Health; Springer: Berlin, Germany, 2014; pp. 53-74.

107. Morozova, O.V.; Sashina, T.A.; Epifanova, N.V.; Kashnikov, A.Y.; Novikova, N.A. Increasing Detection of Rotavirus G2P [4] Strains in Nizhny Novgorod, Russia, between 2016 and 2019. Arch. Virol. 2021, 166, 115-124. [CrossRef]

108. Bányai, K.; László, B.; Duque, J.; Steele, A.D.; Nelson, E.A.S.; Gentsch, J.R.; Parashar, U.D. Systematic Review of Regional and Temporal Trends in Global Rotavirus Strain Diversity in the Pre Rotavirus Vaccine Era: Insights for Understanding the Impact of Rotavirus Vaccination Programs. Vaccine 2012, 30, A122-A130. [CrossRef]

109. Rivera, R.; Forney, K.; Castro, M.R.; Rebolledo, P.A.; Mamani, N.; Patzi, M.; Halkyer, P.; Leon, J.S.; Iñiguez, V. Rotavirus Genotype Distribution during the Pre-Vaccine Period in Bolivia: 2007-2008. Int. J. Infect. Dis. 2013, 17, e762-e767. [CrossRef]

110. Almalki, S.S.R. Molecular Detection of Hepatitis A Virus and Rotavirus in Water Samples Collected from Albaha, Saudi Arabia Egypt. Acad. J. Biol. Sciences. C Physiol. Mol. Biol. 2018, 10, 59-68. [CrossRef]

111. Miura, T.; Gima, A.; Akiba, M. Detection of Norovirus and Rotavirus Present in Suspended and Dissolved Forms in Drinking Water Sources. Food Environ. Virol. 2019, 11, 9-19. [CrossRef]

112. Neveen Magdy, R.; Allayeh, A.K. Genotyping of Rotaviruses in River Nile in Giza, Egypt. Iran. J. Public Health $2020,49,173$.

113. Osuolale, O.; Okoh, A. Human Enteric Bacteria and Viruses in Five Wastewater Treatment Plants in the Eastern Cape, South Africa. J. Infect. Public Health 2017, 10, 541-547. [CrossRef]

114. Yousuf, F.A.; Siddiqui, R.; Khan, N.A. Presence of Rotavirus and Free-Living Amoebae in the Water Supplies of Karachi, Pakistan. Rev. Inst. Med. Trop. São Paulo 2017, 59. [CrossRef]

115. Naqvi, S.S.; Javed, S.; Naseem, S.; Sadiq, A.; Khan, N.; Sattar, S.; Shah, N.A.; Bostan, N. G3 and G9 Rotavirus Genotypes in Waste Water Circulation from Two Major Metropolitan Cities of Pakistan. Sci. Rep. 2020, 10, 1-9. [CrossRef]

116. Kitajima, M.; Iker, B.C.; Pepper, I.L.; Gerba, C.P. Relative Abundance and Treatment Reduction of Viruses during Wastewater Treatment Processes-Identification of Potential Viral Indicators. Sci. Total. Environ. 2014, 488, 290-296. [CrossRef]

117. Fumian, T.M.; Leite, J.P.G.; Rose, T.L.; Prado, T.; Miagostovich, M.P. One Year Environmental Surveillance of Rotavirus Specie A (RVA) Genotypes in Circulation after the Introduction of the Rotarix®Vaccine in Rio de Janeiro, Brazil. Water Res. 2011, 45, 5755-5763. [CrossRef]

118. Ruggeri, F.M.; Bonomo, P.; Ianiro, G.; Battistone, A.; Delogu, R.; Germinario, C.; Chironna, M.; Triassi, M.; Campagnuolo, R.; Cicala, A. Rotavirus Genotypes in Sewage Treatment Plants and in Children Hospitalized with Acute Diarrhea in Italy in 2010 and 2011. Appl. Environ. Microbiol. 2015, 81, 241-249. [CrossRef]

119. Lodder, W.J.; Van Den Berg, H.; Rutjes, S.A.; de Roda Husman, A.M. Presence of Enteric Viruses in Source Waters for Drinking Water Production in The Netherlands. Appl. Environ. Microbiol. 2010, 76, 5965-5971. [CrossRef]

120. Shi, D.; Ma, H.; Miao, J.; Liu, W.; Yang, D.; Qiu, Z.; Shen, Z.; Yin, J.; Yang, Z.; Wang, H. Levels of Human Rotaviruses and Noroviruses GII in Urban Rivers Running through the City Mirror Their Infection Prevalence in Populations. Sci. Total. Environ. 2021, 754, 142203. [CrossRef]

121. Fonager, J.; Stegger, M.; Rasmussen, L.D.; Poulsen, M.W.; Rønn, J.; Andersen, P.S.; Fischer, T.K. A Universal Primer-Independent next-Generation Sequencing Approach for Investigations of Norovirus Outbreaks and Novel Variants. Sci. Rep. 2017, 7, 1-11. [CrossRef]

122. Vinjé, J. Advances in Laboratory Methods for Detection and Typing of Norovirus. J. Clin. Microbiol. 2015, 53, 373. [CrossRef]

123. Ahmed, S.M.; Hall, A.J.; Robinson, A.E.; Verhoef, L.; Premkumar, P.; Parashar, U.D.; Koopmans, M.; Lopman, B.A. Global Prevalence of Norovirus in Cases of Gastroenteritis: A Systematic Review and Meta-Analysis. Lancet Infect. Dis. 2014, 14, 725-730. [CrossRef]

124. Lartey, B.L.; Quaye, O.; Damanka, S.A.; Agbemabiese, C.A.; Armachie, J.; Dennis, F.E.; Enweronu-Laryea, C.; Armah, G.E. Understanding Pediatric Norovirus Epidemiology: A Decade of Study among Ghanaian Children. Viruses 2020, $12,1321$. [CrossRef]

125. Center for Disease Control and Prevention (CDC). Norovirus Worldwide; CDC: Atlanta, GA, USA, 2018.

126. Mans, J. Norovirus Infections and Disease in Lower-Middle-and Low-Income Countries, 1997-2018. Viruses 2019, 11, 341. [CrossRef]

127. Mathew, S.; Alansari, K.; Smatti, M.K.; Zaraket, H.; Al Thani, A.A.; Yassine, H.M. Epidemiological, Molecular, and Clinical Features of Norovirus Infections among Pediatric Patients in Qatar. Viruses 2019, 11, 400. [CrossRef]

128. KY, G.; Knipe DM, H.P.; Cohen, J.L.; Griffin, D.E.; Lamb, R.A.; Martin, M.A.; Racaniello, V.R. Caliciviridae: The Noroviruses. In Fields Virology, 6th ed.; Lippincott Williams \& Wilkins: Philadelphia, PA, USA, 2013; pp. 582-608.

129. Chhabra, P.; de Graaf, M.; Parra, G.I.; Chan, M.C.-W.; Green, K.; Martella, V.; Wang, Q.; White, P.A.; Katayama, K.; Vennema, H. Updated Classification of Norovirus Genogroups and Genotypes. J. Gen. Virol. 2019, 100, 1393. [CrossRef]

130. Parra, G.I.; Squires, R.B.; Karangwa, C.K.; Johnson, J.A.; Lepore, C.; Sosnovtsev, S.V.; Green, K.Y. Static and Evolving Norovirus Genotypes: Implications for Epidemiology and Immunity. PLoS Pathog. 2017, 13, e1006136. [CrossRef] 
131. Caddy, S.L.; De Rougemont, A.; Emmott, E.; El-Attar, L.; Mitchell, J.A.; Hollinshead, M.; Belliot, G.; Brownlie, J.; Le Pendu, J.; Goodfellow, I. Evidence for Human Norovirus Infection of Dogs in the United Kingdom. J. Clin. Microbiol. 2015, $53,1873$. [CrossRef]

132. Caddy, S.; Breiman, A.; le Pendu, J.; Goodfellow, I. Genogroup IV and VI Canine Noroviruses Interact with Histo-Blood Group Antigens. J. Virol. 2014, 88, 10377. [CrossRef]

133. Summa, M.; von Bonsdorff, C.-H.; Maunula, L. Evaluation of Four Virus Recovery Methods for Detecting Noroviruses on Fresh Lettuce, Sliced Ham, and Frozen Raspberries. J. Virol. Methods 2012, 183, 154-160. [CrossRef]

134. Farkas, T. Natural Norovirus Infections in Rhesus Macaques. Emerg. Infect. Dis. 2016, 22, 1272. [CrossRef]

135. Motomura, K.; Yokoyama, M.; Ode, H.; Nakamura, H.; Mori, H.; Kanda, T.; Oka, T.; Katayama, K.; Noda, M.; Tanaka, T. Divergent Evolution of Norovirus GII/4 by Genome Recombination from May 2006 to February 2009 in Japan. J. Virol. 2010, 84, 8085. [CrossRef]

136. Mattison, K.; Shukla, A.; Cook, A.; Pollari, F.; Friendship, R.; Kelton, D.; Bidawid, S.; Farber, J.M. Human Noroviruses in Swine and Cattle. Emerg. Infect. Dis. 2007, 13, 1184. [CrossRef]

137. van Der Poel, W.H.; Vinjé, J.; Van der Heide, R.; Herrera, M.-I.; Vivo, A.; Koopmans, M.P. Norwalk-like Calicivirus Genes in Farm Animals. Emerg. Infect. Dis. 2000, 6, 36. [CrossRef]

138. Jung, K.; Wang, Q.; Kim, Y.; Scheuer, K.; Zhang, Z.; Shen, Q.; Chang, K.-O.; Saif, L.J. The Effects of Simvastatin or Interferon- $\alpha$ on Infectivity of Human Norovirus Using a Gnotobiotic Pig Model for the Study of Antivirals. PLoS ONE 2012, 7, e41619. [CrossRef]

139. Bok, K.; Parra, G.I.; Mitra, T.; Abente, E.; Shaver, C.K.; Boon, D.; Engle, R.; Yu, C.; Kapikian, A.Z.; Sosnovtsev, S.V. Chimpanzees as an Animal Model for Human Norovirus Infection and Vaccine Development. Proc. Natl. Acad. Sci. USA 2011, 108, 325-330. [CrossRef]

140. Souza, M.; Azevedo, M.S.P.; Jung, K.; Cheetham, S.; Saif, L.J. Pathogenesis and Immune Responses in Gnotobiotic Calves after Infection with the Genogroup II. 4-HS66 Strain of Human Norovirus. J. Virol. 2008, 82, 1777. [CrossRef]

141. Wolf, S.; Williamson, W.; Hewitt, J.; Lin, S.; Rivera-Aban, M.; Ball, A.; Scholes, P.; Savill, M.; Greening, G.E. Molecular Detection of Norovirus in Sheep and Pigs in New Zealand Farms. Vet. Microbiol. 2009, 133, 184-189. [CrossRef]

142. Oliver, S.L.; Brown, D.W.G.; Green, J.; Bridger, J.C. A Chimeric Bovine Enteric Calicivirus: Evidence for Genomic Recombination in Genogroup III of the Norovirus Genus of the Caliciviridae. Virology 2004, 326, 231-239. [CrossRef]

143. Smith, D.B.; McFadden, N.; Blundell, R.J.; Meredith, A.; Simmonds, P. Diversity of Murine Norovirus in Wild-Rodent Populations: Species-Specific Associations Suggest an Ancient Divergence. J. Gen. Virol. 2012, 93, 259-266. [CrossRef]

144. Karst, S.M.; Wobus, C.E.; Lay, M.; Davidson, J.; Virgin, H.W. STAT1-Dependent Innate Immunity to a Norwalk-like Virus. Science 2003, 299, 1575-1578. [CrossRef]

145. Ford-Siltz, L.A.; Mullis, L.; Sanad, Y.M.; Tohma, K.; Lepore, C.J.; Azevedo, M.; Parra, G.I. Genomics Analyses of GIV and GVI Noroviruses Reveal the Distinct Clustering of Human and Animal Viruses. Viruses 2019, 11, 204. [CrossRef]

146. Di Martino, B.; Di Profio, F.; Melegari, I.; Sarchese, V.; Cafiero, M.A.; Robetto, S.; Aste, G.; Lanave, G.; Marsilio, F.; Martella, V. A Novel Feline Norovirus in Diarrheic Cats. Infect. Genet. Evol. 2016, 38, 132-137. [CrossRef]

147. Martella, V.; Lorusso, E.; Decaro, N.; Elia, G.; Radogna, A.; D’Abramo, M.; Desario, C.; Cavalli, A.; Corrente, M.; Camero, M.; et al. Detection and Molecular Characterization of a Canine Norovirus. Emerg. Infect. Dis. 2008, 14, 1306-1308. [CrossRef]

148. Wang, Q.-H.; Han, M.G.; Cheetham, S.; Souza, M.; Funk, J.A.; Saif, L.J. Porcine Noroviruses Related to Human Noroviruses. Emerg. Infect. Dis. 2005, 11, 1874. [CrossRef]

149. Parra, G.I. Emergence of Norovirus Strains: A Tale of Two Genes. Virus Evol. 2019, 5, vez048. [CrossRef]

150. Lu, Y.; Ma, M.; Wang, H.; Wang, D.; Chen, C.; Jing, Q.; Geng, J.; Li, T.; Zhang, Z.; Yang, Z. An Outbreak of Norovirus-Related Acute Gastroenteritis Associated with Delivery Food in Guangzhou, Southern China. BMC Public Health 2020, 20, 1-7. [CrossRef]

151. Xue, L.; Cai, W.; Gao, J.; Zhang, L.; Dong, R.; Li, Y.; Wu, H.; Chen, M.; Zhang, J.; Wang, J. The Resurgence of the Norovirus GII. 4 Variant Associated with Sporadic Gastroenteritis in the Post-GII. 17 Period in South China, 2015 to 2017. BMC Infect. Dis. 2019, 19, 1-8. [CrossRef]

152. Ge, L.; Chen, X.; Liu, J.; Zheng, L.; Chen, C.; Luo, S.; Guo, P.; Kong, J.; Song, Y.; Huo, Y. Genomic and Biological Characterization of a Pandemic Norovirus Variant GII. 4 Sydney 2012. Virus Genes 2020, 1-8. [CrossRef]

153. Tohma, K.; Lepore, C.J.; Gao, Y.; Ford-Siltz, L.A.; Parra, G.I. Population Genomics of GII. 4 Noroviruses Reveal Complex Diversification and New Antigenic Sites Involved in the Emergence of Pandemic Strains. MBio 2019, 10. [CrossRef]

154. Robilotti, E.; Deresinski, S.; Pinsky, B.A. Norovirus. Clin. Microbiol. Rev. 2015, 28, 134. [CrossRef]

155. Bull, R.A.; Eden, J.-S.; Rawlinson, W.D.; White, P.A. Rapid Evolution of Pandemic Noroviruses of the GII. 4 Lineage. PLoS Pathog. 2010, 6, e1000831. [CrossRef]

156. Bitler, E.J.; Matthews, J.E.; Dickey, B.W.; Eisenberg, J.N.S.; Leon, J.S. Norovirus Outbreaks: A Systematic Review of Commonly Implicated Transmission Routes and Vehicles. Epidemiol. Infect. 2013, 141, 1563-1571. [CrossRef]

157. Lei, H.; Li, Y.; Xiao, S.; Lin, C.-H.; Norris, S.L.; Wei, D.; Hu, Z.; Ji, S. Routes of Transmission of Influenza A H1N1, SARS CoV, and Norovirus in Air Cabin: Comparative Analyses. Indoor Air 2018, 28, 394-403. [CrossRef]

158. Xiao, S.; Tang, J.W.; Li, Y. Airborne or Fomite Transmission for Norovirus? A Case Study Revisited. Int. J. Environ. Res. Public Health 2017, 14, 1571. [CrossRef]

159. de Graaf, M.; van Beek, J.; Koopmans, M.P. Human Norovirus Transmission and Evolution in a Changing World. Nat. Rev. Microbiol. 2016, 14, 421-433. [CrossRef] 
160. Bernstein, D.I.; Atmar, R.L.; Lyon, G.M.; Treanor, J.J.; Chen, W.H.; Jiang, X.; Vinjé, J.; Gregoricus, N.; Frenck, R.W., Jr.; Moe, C.L. Norovirus Vaccine against Experimental Human GII. 4 Virus Illness: A Challenge Study in Healthy Adults. J. Infect. Dis. 2015, 211, 870-878. [CrossRef]

161. Teunis, P.F.; Moe, C.L.; Liu, P.; Miller, S.E.; Lindesmith, L.; Baric, R.S.; Le Pendu, J.; Calderon, R.L. Norwalk Virus: How Infectious Is It? J. Med Virol. 2008, 80, 1468-1476. [CrossRef]

162. Dolin, R.; Blacklow, N.R.; DuPont, H.; Formal, S.; Buscho, R.F.; Kasel, J.A.; Chames, R.P.; Hornick, R.; Chanock, R.M. Transmission of Acute Infectious Nonbacterial Gastroenteritis to Volunteers by Oral Administration of Stool Filtrates. J. Infect. Dis. 1971, 123, 307-312. [CrossRef]

163. Stegmaier, T.; Oellingrath, E.; Himmel, M.; Fraas, S. Differences in Epidemic Spread Patterns of Norovirus and Influenza Seasons of Germany: An Application of Optical Flow Analysis in Epidemiology. Sci. Rep. 2020, 10, 1-14. [CrossRef]

164. Richards, G.P.; Watson, M.A.; Meade, G.K.; Hovan, G.L.; Kingsley, D.H. Resilience of Norovirus GII. 4 to Freezing and Thawing: Implications for Virus Infectivity. Food Environ. Virol. 2012, 4, 192-197. [CrossRef]

165. Kauppinen, A.; Miettinen, I.T. Persistence of Norovirus GII Genome in Drinking Water and Wastewater at Different Temperatures. Pathogens 2017, 6, 48. [CrossRef]

166. Bozkurt, H.; D'Souza, D.H.; Davidson, P.M. Thermal Inactivation Kinetics of Human Norovirus Surrogates and Hepatitis A Virus in Turkey Deli Meat. Appl. Environ. Microbiol. 2015, 81, 4850. [CrossRef]

167. Cromeans, T.; Park, G.W.; Costantini, V.; Lee, D.; Wang, Q.; Farkas, T.; Lee, A.; Vinjé, J. Comprehensive Comparison of Cultivable Norovirus Surrogates in Response to Different Inactivation and Disinfection Treatments. Appl. Environ. Microbiol. 2014, 80, 5743. [CrossRef]

168. Robin, M.; Chassaing, M.; Loutreul, J.; de Rougemont, A.; Belliot, G.; Majou, D.; Gantzer, C.; Boudaud, N. Effect of Natural Ageing and Heat Treatments on GII. 4 Norovirus Binding to Histo-Blood Group Antigens. Sci. Rep. 2019, 9, 1-11. [CrossRef]

169. Wu, H.M.; Fornek, M.; Schwab, K.J.; Chapin, A.R.; Gibson, K.; Schwab, E.; Spencer, C.; Henning, K. A Norovirus Outbreak at a Long-Term-Care Facility: The Role of Environmental Surface Contamination. Infect. Control. Hosp. Epidemiol. 2005, 26, 802-810. [CrossRef]

170. Redwan, N.A.; Bagatadah, R.A. Health Risk Assessment Associated with Norovirus Incidence in Raw Wastewater in Jeddah, Saudi Arabia. Austr. J. Basic Appl. Sci. 2012, 6, 43-48.

171. Shaheen, M.N.; Elmahdy, E.M. Environmental Monitoring of Astrovirus and Norovirus in the Rosetta Branch of the River Nile and the El-Rahawy Drain, Egypt. Water Supply 2019, 19, 1381-1387. [CrossRef]

172. Shaheen, M.N.F.; Abd El-Daim, S.E.; Ahmed, N.I.; Elmahdy, E.M. Molecular Detection of Three Gastroenteritis Viruses in an Urban Sewage Treatment Plant and River Water in Egypt. Egypt. J. Aquat. Biol. Fish. 2018, 22, 615-627. [CrossRef]

173. Nakamura, K.; Iwai, M.; Zhang, J.; Obara, M.; Horimoto, E.; Hasegawa, S.; Kurata, T.; Takizawa, T. Detection of a Novel Recombinant Norovirus from Sewage Water in Toyama Prefecture, Japan. Jpn. J. Infect. Dis. 2009, 62, 394-398.

174. Kitajima, M.; Haramoto, E.; Phanuwan, C.; Katayama, H.; Ohgaki, S. Detection of Genogroup IV Norovirus in Wastewater and River Water in Japan. Lett. Appl. Microbiol. 2009, 49, 655-658. [CrossRef]

175. Mabasa, V.V.; Meno, K.D.; Taylor, M.B.; Mans, J. Environmental Surveillance for Noroviruses in Selected South African Wastewaters 2015-2016: Emergence of the Novel GII. 17. Food Environ. Virol. 2018, 10, 16-28. [CrossRef]

176. Mans, J.; Netshikweta, R.; Magwalivha, M.; Van Zyl, W.B.; Taylor, M.B. Diverse Norovirus Genotypes Identified in SewagePolluted River Water in South Africa. Epidemiol. Infect. 2013, 141, 303-313. [CrossRef]

177. Bivins, A.; Lowry, S.; Wankhede, S.; Hajare, R.; Murphy, H.M.; Borchardt, M.; Labhasetwar, P.; Brown, J. Microbial Water Quality Improvement Associated with Transitioning from Intermittent to Continuous Water Supply in Nagpur, India. Water Res. 2021, 117301. [CrossRef]

178. Jahne, M.A.; Brinkman, N.E.; Keely, S.P.; Zimmerman, B.D.; Wheaton, E.A.; Garland, J.L. Droplet Digital PCR Quantification of Norovirus and Adenovirus in Decentralized Wastewater and Graywater Collections: Implications for Onsite Reuse. Water Res. 2020, 169, 115213. [CrossRef]

179. Rosiles-González, G.; Ávila-Torres, G.; Moreno-Valenzuela, O.A.; Cháidez-Quiroz, C.; Hernández-Flores, C.I.; AcostA-González, G.; Brown, J.K.; Betancourt, W.Q.; Gerba, C.P.; Hernández-Zepeda, C. Norovirus and Human Adenovirus Occurrence and Diversity in Recreational Water in a Karst Aquifer in the Yucatan Peninsula, Mexico. J. Appl. Microbiol. 2019, 127, 1255-1269. [CrossRef]

180. Myrmel, M.; Lange, H.; Rimstad, E. A 1-Year Quantitative Survey of Noro-, Adeno-, Human Boca-, and Hepatitis E Viruses in Raw and Secondarily Treated Sewage from Two Plants in Norway. Food Environ. Virol. 2015, 7, 213-223. [CrossRef]

181. Fumian, T.M.; Fioretti, J.M.; Lun, J.H.; Dos Santos, I.A.; White, P.A.; Miagostovich, M.P. Detection of Norovirus Epidemic Genotypes in Raw Sewage Using next Generation Sequencing. Environ. Int. 2019, 123, 282-291. [CrossRef]

182. Bonadonna, L.; Briancesco, R.; Suffredini, E.; Coccia, A.; Della Libera, S.; Carducci, A.; Verani, M.; Federigi, I.; Iaconelli, M.; Ferraro, G.B. Enteric Viruses, Somatic Coliphages and Vibrio Species in Marine Bathing and Non-Bathing Waters in Italy. Mar. Pollut. Bull. 2019, 149, 110570. [CrossRef]

183. Lodder, W.J.; de Roda Husman, A.M. Presence of Noroviruses and Other Enteric Viruses in Sewage and Surface Waters in The Netherlands. Appl. Environ. Microbiol. 2005, 71, 1453-1461. [CrossRef] 
184. Shang, X.; Fu, X.; Zhang, P.; Sheng, M.; Song, J.; He, F.; Qiu, Y.; Wu, H.; Lu, Q.; Feng, Y. An Outbreak of Norovirus-Associated Acute Gastroenteritis Associated with Contaminated Barrelled Water in Many Schools in Zhejiang, China. PLoS ONE 2017, 12, e0171307. [CrossRef]

185. Zhou, X.; Kong, D.-G.; Li, J.; Pang, B.-B.; Zhao, Y.; Zhou, J.-B.; Zhang, T.; Xu, J.-Q.; Kobayashi, N.; Wang, Y.-H. An Outbreak of Gastroenteritis Associated with GII. 17 Norovirus-Contaminated Secondary Water Supply System in Wuhan, China, 2017. Food Environ. Virol. 2019, 11, 126-137. [CrossRef]

186. McKnight, K.L.; Lemon, S.M. Hepatitis A Virus Genome Organization and Replication Strategy. Cold Spring Harb. Perspect. Med. 2018, 8, a033480. [CrossRef]

187. Blight, K.J.; Grakoui, A.; Hanson, H.L.; Rice, C.M. The molecular biology of hepatitis C virus. In Hepatitis Viruses; Springer: Berlin, Germany, 2002; pp. 81-108.

188. Gosert, R.; Cassinotti, P.; Siegl, G.; Weitz, M. Identification of Hepatitis A Virus Non-Structural Protein 2B and Its Release by the Major Virus Protease 3C. J. Gen. Virol. 1996, 77, 247-255. [CrossRef]

189. Vaughan, G.; Xia, G.; Forbi, J.C.; Purdy, M.A.; Rossi, L.M.G.; Spradling, P.R.; Khudyakov, Y.E. Genetic Relatedness among Hepatitis A Virus Strains Associated with Food-Borne Outbreaks. PLoS ONE 2013, 8, e74546. [CrossRef]

190. Lemon, S.M.; Ott, J.J.; Van Damme, P.; Shouval, D. Type A Viral Hepatitis: A Summary and Update on the Molecular Virology, Epidemiology, Pathogenesis and Prevention. J. Hepatol. 2018, 68, 167-184. [CrossRef]

191. Drexler, J.F.; Corman, V.M.; Lukashev, A.N.; van den Brand, J.M.; Gmyl, A.P.; Bruenink, S.; Rasche, A.; Seggewi $\beta$, N.; Feng, H.; Leijten, L.M. Evolutionary Origins of Hepatitis A Virus in Small Mammals. Proc. Natl. Acad. Sci. USA 2015, 112, 15190-15195. [CrossRef]

192. Wang, H.; Zheng, H.; Cao, J.; Zhou, W.; Yi, Y.; Jia, Z.; Bi, S. Genetic Diversity of Hepatitis A Virus in China: VP3-VP1-2A Genes and Evidence of Quasispecies Distribution in the Isolates. PLoS ONE 2013, 8, e74752. [CrossRef]

193. Bruni, R.; Taffon, S.; Equestre, M.; Cella, E.; Presti, A.L.; Costantino, A.; Chionne, P.; Madonna, E.; Golkocheva-Markova, E.; Bankova, D. Hepatitis a Virus Genotypes and Strains from an Endemic Area of Europe, Bulgaria 2012-2014. BMC Infect. Dis. 2017, 17, 1-8. [CrossRef]

194. Yilmaz, H.; Karakullukcu, A.; Turan, N.; Cizmecigil, U.Y.; Yilmaz, A.; Ozkul, A.A.; Aydin, O.; Gunduz, A.; Mete, M.; Zeyrek, F.Y. Genotypes of Hepatitis a Virus in Turkey: First Report and Clinical Profile of Children Infected with Sub-Genotypes IA and IIIA. BMC Infect. Dis. 2017, 17, 1-8. [CrossRef]

195. D’Andrea, L.; Pérez-Rodríguez, F.J.; De Castellarnau, M.; Manzanares, S.; Lite, J.; Guix, S.; Bosch, A.; Pintó, R.M. Hepatitis A Virus Genotype Distribution during a Decade of Universal Vaccination of Preadolescents. Int. J. Mol. Sci. 2015, 16, 6842-6854 [CrossRef]

196. Roque-Afonso, A.M.; Desbois, D.; Dussaix, E. Hepatitis A Virus: Serology and Molecular Diagnostics. Future Virol. 2010, 5, 233-242. [CrossRef]

197. Robertson, B.H.; Jansen, R.W.; Khanna, B.; Totsuka, A.; Nainan, O.V.; Siegl, G.; Widell, A.; Margolis, H.S.; Isomura, S.; Ito, K. Genetic Relatedness of Hepatitis A Virus Strains Recovered from Different Geographical Regions. J. Gen. Virol. 1992, 73, 1365-1377. [CrossRef]

198. de Oliveira Carneiro, I.; Sander, A.-L.; Silva, N.; Moreira-Soto, A.; Normann, A.; Flehmig, B.; Lukashev, A.N.; Dotzauer, A.; Wieseke, N.; Franke, C.R. A Novel Marsupial Hepatitis A Virus Corroborates Complex Evolutionary Patterns Shaping the Genus Hepatovirus. J. Virol. 2018, 92. [CrossRef]

199. La Rosa, G.; Mancini, P.; Bonanno Ferraro, G.; Iaconelli, M.; Veneri, C.; Paradiso, R.; De Medici, D.; Vicenza, T.; Proroga, Y.T.R.; Di Maro, O. Hepatitis A Virus Strains Circulating in the Campania Region (2015-2018) Assessed through Bivalve Biomonitoring and Environmental Surveillance. Viruses 2021, 13, 16. [CrossRef]

200. Walker, C.M. Adaptive Immune Responses in Hepatitis A Virus and Hepatitis E Virus Infections. Cold Spring Harb. Perspect. Med. 2019, 9, a033472. [CrossRef]

201. World Health Organization. Hepatitis A; WHO: Geneva, Switzerland, 2020.

202. Benjamin, M.; Agnihotry, S.; Srivastava, A.; Bolia, R.; Yachha, S.K.; Aggarwal, R. Relationship of Severity of Hepatitis a with Polymorphisms in Hepatitis a Virus Cellular Receptor 1 (HAVCR1) Gene. Ann. Hepatol. 2018, 17, 561-568. [CrossRef]

203. Matheny, S.C.; Kingery, J.E. Hepatitis A. Am. Fam. Physician 2012, 86, 1027-1034.

204. Jeong, S.-H.; Lee, H.-S. Hepatitis A: Clinical Manifestations and Management. Intervirology 2010, 53, 15-19. [CrossRef]

205. Nelson, N.P.; Weng, M.K.; Hofmeister, M.G.; Moore, K.L.; Doshani, M.; Kamili, S.; Koneru, A.; Haber, P.; Hagan, L.; Romero, J.R. Prevention of Hepatitis A Virus Infection in the United States: Recommendations of the Advisory Committee on Immunization Practices; Center for Disease Control and Prevention: Atlanta, GA, USA, 2020.

206. Augustine, S.A.J.; Eason, T.N.; Simmons, K.J.; Griffin, S.M.; Curioso, C.L.; Ramudit, M.K.D.; Sams, E.A.; Oshima, K.H.; Dufour, A.; Wade, T.J. Rapid Salivary IgG Antibody Screening for Hepatitis A. J. Clin. Microbiol. 2020, 58. [CrossRef]

207. Nainan, O.V.; Xia, G.; Vaughan, G.; Margolis, H.S. Diagnosis of Hepatitis A Virus Infection: A Molecular Approach. Clin. Microbiol. Rev. 2006, 19, 63. [CrossRef]

208. Fujiwara, K.; Yokosuka, O.; Fukai, K.; Imazeki, F.; Saisho, H.; Omata, M. Analysis of Full-Length Hepatitis A Virus Genome in Sera from Patients with Fulminant and Self-Limited Acute Type A Hepatitis. J. Hepatol. 2001, 35, 112-119. [CrossRef] 
209. Behzadi, M.A.; LeyvA-Grado, V.H.; Namayandeh, M.; Ziyaeyan, A.; Feyznezhad, R.; Dorzaban, H.; Jamalidoust, M.; Ziyaeyan, M. Seroprevalence of Viral Hepatitis A, B, C, D and E Viruses in the Hormozgan Province Southern Iran. BMC Infect. Dis. 2019, 19, 1-12. [CrossRef]

210. Barrett, C.E. Impact of Public Health Interventions on Drinking Water-Associated Outbreaks of Hepatitis A-United States, 1971-2017. MMWR. Morb. Mortal. Wkly. Rep. 2019, 68. [CrossRef]

211. Sánchez, G.; Bosch, A. Survival of Enteric Viruses in the Environment and Food. Viruses Foods 2016, $367-392$.

212. Biziagos, E.; Passagot, J.; Crance, J.-M.; Deloince, R. Long-Term Survival of Hepatitis A Virus and Poliovirus Type 1 in Mineral Water. Appl. Environ. Microbiol. 1988, 54, 2705. [CrossRef]

213. Sewlikar, S.; D'Souza, D.H. Survival of Hepatitis A Virus and Aichi Virus in Cranberry-Based Juices at Refrigeration ( $\left.4{ }^{\circ} \mathrm{C}\right)$. Food Microbiol. 2017, 62, 251-255. [CrossRef]

214. Scholz, E.; Heinricy, U.; Flehmig, B. Acid Stability of Hepatitis A Virus. J. Gen. Virol. 1989, 70, 2481-2485. [CrossRef]

215. Agrawal, A.; Singh, S.; Kolhapure, S.; Hoet, B.; Arankalle, V.; Mitra, M. Increasing Burden of Hepatitis A in Adolescents and Adults and the Need for Long-Term Protection: A Review from the Indian Subcontinent. Infect. Dis. Ther. 2019, 8, $483-497$. [CrossRef]

216. Sánchez, G.; Bosch, A.; Pintó, R.M. Genome Variability and Capsid Structural Constraints of Hepatitis A Virus. J. Virol. 2003, 77, 452. [CrossRef] [PubMed]

217. Randazzo, W.; Sánchez, G. Hepatitis A Infections from Food. J. Appl. Microbiol. 2020, 129, 1120-1132. [CrossRef]

218. Scavia, G.; Alfonsi, V.; Taffon, S.; Escher, M.; Bruni, R.; De Medici, D.; Di Pasquale, S.; Guizzardi, S.; Cappelletti, B.; Iannazzo, S. A Large Prolonged Outbreak of Hepatitis A Associated with Consumption of Frozen Berries, Italy, 2013-2014. J. Med Microbiol. 2017, 66, 342-349. [CrossRef] [PubMed]

219. Severi, E.; Verhoef, L.; Thornton, L.; Guzman-Herrador, B.R.; Faber, M.; Sundqvist, L.; Rimhanen-Finne, R.; Roque-Afonso, A.M.; Ngui, S.L.; Allerberger, F. Large and Prolonged Food-Borne Multistate Hepatitis A Outbreak in Europe Associated with Consumption of Frozen Berries, 2013 to 2014. Eurosurveillance 2015, 20, 21192. [CrossRef] [PubMed]

220. Romalde, J.L.; Rivadulla, E.; Varela, M.F.; Barja, J.L. An Overview of 20 Years of Studies on the Prevalence of Human Enteric Viruses in Shellfish from Galicia, Spain. J. Appl. Microbiol. 2018, 124, 943-957. [CrossRef]

221. La Bella, G.; Martella, V.; Basanisi, M.G.; Nobili, G.; Terio, V.; La Salandra, G. Food-Borne Viruses in Shellfish: Investigation on Norovirus and HAV Presence in Apulia (SE Italy). Food Environ. Virol. 2017, 9, 179-186. [CrossRef]

222. Polo, D.; Feal, X.; Romalde, J.L. Mathematical Model for Viral Depuration Kinetics in Shellfish: An Useful Tool to Estimate the Risk for the Consumers. Food Microbiol. 2015, 49, 220-225. [CrossRef]

223. Amon, J.J.; Devasia, R.; Xia, G.; Nainan, O.V.; Hall, S.; Lawson, B.; Wolthuis, J.S.; MacDonald, P.D.; Shepard, C.W.; Williams, I.T. Molecular Epidemiology of Foodborne Hepatitis A Outbreaks in the United States, 2003. J. Infect. Dis. 2005, 192, 1323-1330. [CrossRef]

224. Janahi, E.M.; Mustafa, S.; Parkar, S.F.; Naser, H.A.; Eisa, Z.M. Detection of Enteric Viruses and Bacterial Indicators in a Sewage Treatment Center and Shallow Water Bay. Int. J. Environ. Res. Public Health 2020, 17, 6483. [CrossRef]

225. Hamza, H.; Abd-Elshafy, D.N.; Fayed, S.A.; Bahgat, M.M.; El-Esnawy, N.A.; Abdel-Mobdy, E. Detection and Characterization of Hepatitis A Virus Circulating in Egypt. Arch. Virol. 2017, 162, 1921-1931. [CrossRef]

226. Ouardani, I.; Turki, S.; Aouni, M.; Romalde, J.L. Detection and Molecular Characterization of Hepatitis A Virus from Tunisian Wastewater Treatment Plants with Different Secondary Treatments. Appl. Environ. Microbiol. 2016, 82, 3834-3845. [CrossRef]

227. Beji-Hamza, A.; Khélifi-Gharbi, H.; Hassine-Zaafrane, M.; Della Libera, S.; Iaconelli, M.; Muscillo, M.; Petricca, S.; Ciccaglione, A.R.; Bruni, R.; Taffon, S. Qualitative and Quantitative Assessment of Hepatitis A Virus in Wastewaters in Tunisia. Food Environ. Virol. 2014, 6, 246-252. [CrossRef]

228. Fumian, T.M.; Victoria, M.; Vieira, C.B.; Fioretti, J.M.; Rocha, M.S.; Prado, T.; Guimarães, F.R.; da Gama, N.P.; de Oliveira, J.M.; Mendes, A.C.O. Enteric Viruses' Dissemination in a Private Reserve of Natural Heritage. Lett. Appl. Microbiol. 2018, 66, 313-320. [CrossRef] [PubMed]

229. Saïd, R.; Wolfaardt, M.; Taylor, M.B. Molecular Characterisation of Hepatitis A Virus Strains from Water Sources in South Africa. Water Sci. Technol. 2014, 69, 923-933. [CrossRef]

230. Rachida, S.; Matsapola, P.N.; Wolfaardt, M.; Taylor, M.B. Genetic Characterization of a Novel Hepatitis A Virus Strain in Irrigation Water in South Africa. J. Med Virol. 2016, 88, 734-737. [CrossRef]

231. Ahmad, T.; Arshad, N.; Adnan, F. Prevalence of Rotavirus, Adenovirus, Hepatitis A Virus and Enterovirus in Water Samples Collected from Different Region of Peshawar, Pakistan. Ann. Agric. Environ. Med. 2016, 23, 576-580. [CrossRef]

232. Serres, G.D.; Cromeans, T.L.; Levesque, B.; Brassard, N.; Barthe, C.; Dionne, M.; Prud'homme, H.; Paradis, D.; Shapiro, C.N.; Nainan, O.V. Molecular Confirmation of Hepatitis A Virus from Well Water: Epidemiology and Public Health Implications. J. Infect. Dis. 1999, 179, 37-43. [CrossRef]

233. de Souza, F.G.; da Silva, F.P.; Staggemeier, R.; Rigotto, C.; Spilki, F.R. Low Occurrence of Hepatitis A Virus in Water Samples from an Urban Area of Southern Brazil. Rev. Inst. Med. Trop. São Paulo 2018, 60, e69. [CrossRef]

234. Iaconelli, M.; Purpari, G.; Della Libera, S.; Petricca, S.; Guercio, A.; Ciccaglione, A.R.; Bruni, R.; Taffon, S.; Equestre, M.; Fratini, M. Hepatitis A and E Viruses in Wastewaters, in River Waters, and in Bivalve Molluscs in Italy. Food Environ. Virol. 2015, 7, 316-324. [CrossRef] 
235. Truchado, P.; Garre, A.; Gil, M.I.; Simón-Andreu, P.J.; Sánchez, G.; Allende, A. Monitoring of Human Enteric Virus and Coliphages throughout Water Reuse System of Wastewater Treatment Plants to Irrigation Endpoint of Leafy Greens. Sci. Total. Environ. 2021, 782, 146837. [CrossRef] [PubMed]

236. Yang, N.; Chu, D.L.H.; Wong, M.M.L.; Qi, H.; Wu, R.S.S.; Kong, R.Y.C. Major Human Hepatitis A Virus Genotype in Hong Kong Marine Waters and Detection by Real-Time PCR. Mar. Pollut. Bull. 2011, 62, 2654-2658. [CrossRef] [PubMed]

237. Schuster, C.J.; Aramini, J.J.; Ellis, A.G.; Marshall, B.J.; Robertson, W.J.; Medeiros, D.T.; Charron, D.F. Infectious Disease Outbreaks Related to Drinking Water in Canada, 1974-2001. Can. J. Public Health 2005, 96, 254-258. [CrossRef]

238. Fernández-Correa, I.; Truchado, D.A.; Gomez-Lucia, E.; Doménech, A.; Pérez-Tris, J.; Schmidt-Chanasit, J.; Cadar, D.; Benítez, L. A Novel Group of Avian Astroviruses from Neotropical Passerine Birds Broaden the Diversity and Host Range of Astroviridae. Sci. Rep. 2019, 9, 1-9. [CrossRef] [PubMed]

239. Lulla, V.; Firth, A.E. A Hidden Gene in Astroviruses Encodes a Viroporin. Nat. Commun. 2020, 11. [CrossRef] [PubMed]

240. Toh, Y.; Harper, J.; Dryden, K.A.; Yeager, M.; Arias, C.F.; Méndez, E.; Tao, Y.J. Crystal Structure of the Human Astrovirus Capsid Protein. J. Virol. 2016, 90, 9008. [CrossRef]

241. Fuentes, C.; Bosch, A.; Pintó, R.M.; Guix, S. Identification of Human Astrovirus Genome-Linked Protein (VPg) Essential for Virus Infectivity. J. Virol. 2012, 86, 10070. [CrossRef]

242. Goodfellow, I. The Genome-Linked Protein VPg of Vertebrate Viruses-A Multifaceted Protein. Curr. Opin. Virol. 2011, 1, 355-362. [CrossRef]

243. Vu, D.-L.; Sabrià, A.; Aregall, N.; Michl, K.; Rodriguez Garrido, V.; Goterris, L.; Bosch, A.; Pintó, R.M.; Guix, S. Novel Human Astroviruses: Prevalence and Association with Common Enteric Viruses in Undiagnosed Gastroenteritis Cases in Spain. Viruses 2019, 11, 585. [CrossRef]

244. Hargest, V.; Davis, A.; Schultz-Cherry, S. Astroviridae. Elsevier 2019.

245. Soares, C.C.; de Albuquerque, M.C.M.; Maranhão, A.G.; Rocha, L.N.; Ramírez, M.L.G.; Benati, F.J.; do Carmo Timenetsky, M.; Santos, N. Astrovirus Detection in Sporadic Cases of Diarrhea among Hospitalized and Non-Hospitalized Children in Rio De Janeiro, Brazil, from 1998 to 2004. J. Med Virol. 2008, 80, 113-117. [CrossRef]

246. Espul, C.; Martínez, N.; Noel, J.S.; Cuello, H.; Abrile, C.; Grucci, S.; Glass, R.; Berke, T.; Matson, D.O. Prevalence and Characterization of Astroviruses in Argentinean Children with Acute Gastroenteritis. J. Med Virol. 2004, 72, 75-82. [CrossRef]

247. De Benedictis, P.; Schultz-Cherry, S.; Burnham, A.; Cattoli, G. Astrovirus Infections in Humans and Animals-Molecular Biology, Genetic Diversity, and Interspecies Transmissions. Infect. Genet. Evol. 2011, 11, 1529-1544. [CrossRef]

248. Bosch, A.; Pintó, R.M.; Guix, S. Human Astroviruses. Clin. Microbiol. Rev. 2014, 27, 1048. [CrossRef]

249. Vu, D.-L.; Bosch, A.; Pintó, R.M.; Guix, S. Epidemiology of Classic and Novel Human Astrovirus: Gastroenteritis and Beyond. Viruses 2017, 9, 33. [CrossRef] [PubMed]

250. Pérez-Rodriguez, F.J.; Vieille, G.; Turin, L.; Yildiz, S.; Tapparel, C.; Kaiser, L. Fecal Components Modulate Human Astrovirus Infectivity in Cells and Reconstituted Intestinal Tissues. Msphere 2019, 4. [CrossRef]

251. Prevost, B.; Lucas, F.S.; Ambert-Balay, K.; Pothier, P.; Moulin, L.; Wurtzer, S. Deciphering the Diversities of Astroviruses and Noroviruses in Wastewater Treatment Plant Effluents by a High-Throughput Sequencing Method. Appl. Environ. Microbiol. 2015, 81, 7215. [CrossRef] [PubMed]

252. Thongprachum, A.; Fujimoto, T.; Takanashi, S.; Saito, H.; Okitsu, S.; Shimizu, H.; Khamrin, P.; Maneekarn, N.; Hayakawa, S.; Ushijima, H. Detection of Nineteen Enteric Viruses in Raw Sewage in Japan. Infect. Genet. Evol. 2018, 63, 17-23. [CrossRef] [PubMed]

253. Van Zyl, W.B.; Zhou, N.A.; Wolfaardt, M.; Matsapola, P.N.; Ngwana, F.B.; Symonds, E.M.; Fagnant-Sperati, C.S.; Shirai, J.H.; Kossik, A.L.; Beck, N.K. Detection of Potentially Pathogenic Enteric Viruses in Environmental Samples from Kenya Using the Bag-Mediated Filtration System. Water Supply 2019, 19, 1668-1676. [CrossRef]

254. Kiulia, N.M.; Netshikweta, R.; Page, N.A.; Van Zyl, W.B.; Kiraithe, M.M.; Nyachieo, A.; Mwenda, J.M.; Taylor, M.B. The Detection of Enteric Viruses in Selected Urban and Rural River Water and Sewage in Kenya, with Special Reference to Rotaviruses. J. Appl. Microbiol. 2010, 109, 818-828. [CrossRef]

255. Victoria, M.; Tort, L.L.; García, M.; Lizasoain, A.; Maya, L.; Leite, J.P.G.; Miagostovich, M.P.; Cristina, J.; Colina, R. Assessment of Gastroenteric Viruses from Wastewater Directly Discharged into Uruguay River, Uruguay. Food Environ. Virol. 2014, 6, 116-124. [CrossRef]

256. Taylor, M.B.; Cox, N.; Vrey, M.A.; Grabow, W.O.K. The Occurrence of Hepatitis A and Astroviruses in Selected River and Dam Waters in South Africa. Water Res. 2001, 35, 2653-2660. [CrossRef]

257. Hata, A.; Kitajima, M.; Haramoto, E.; Lee, S.; Ihara, M.; Gerba, C.P.; Tanaka, H. Next-Generation Amplicon Sequencing Identifies Genetically Diverse Human Astroviruses, Including Recombinant Strains, in Environmental Waters. Sci. Rep. 2018, 8, 1-9. [CrossRef]

258. Miagostovich, M.P.; Ferreira, F.F.; Guimarães, F.R.; Fumian, T.M.; Diniz-Mendes, L.; Luz, S.L.B.; Silva, L.A.; Leite, J.P.G. Molecular Detection and Characterization of Gastroenteritis Viruses Occurring Naturally in the Stream Waters of Manaus, Central Amazonia, Brazil. Appl. Environ. Microbiol. 2008, 74, 375-382. [CrossRef] [PubMed]

259. Cioffi, B.; Ianiro, G.; Iaccarino, D.; D’Apice, F.; Ferraro, A.; Race, M.; Spasiano, D.; Esposito, E.; Monini, M.; Serra, F. A Potential Risk Assessment Tool to Monitor Pathogens Circulation in Coastal Waters. Environ. Res. 2021, 200, 111748. [CrossRef] 
260. Smith, A.; Reacher, M.; Smerdon, W.; Adak, G.K.; Nichols, G.; Chalmers, R.M. Outbreaks of Waterborne Infectious Intestinal Disease in England and Wales, 1992-2003. Epidemiol. Infect. 2006, 134, 1141-1149. [CrossRef] [PubMed]

261. He, X.Q.; Cheng, L.; Zhang, D.Y.; Xie, X.M.; Wang, D.H.; Wang, Z. One-Year Monthly Survey of Rotavirus, Astrovirus and Norovirus in Three Sewage Treatment Plants in Beijing, China and Associated Health Risk Assessment. Water Sci. Technol. 2011, 63, 191-198. [CrossRef] [PubMed]

262. Prevost, B.; Lucas, F.S.; Goncalves, A.; Richard, F.; Moulin, L.; Wurtzer, S. Large Scale Survey of Enteric Viruses in River and Waste Water Underlines the Health Status of the Local Population. Environ. Int. 2015, 79, 42-50. [CrossRef] [PubMed]

263. Espinosa, A.C.; Mazari-Hiriart, M.; Espinosa, R.; Maruri-Avidal, L.; Méndez, E.; Arias, C.F. Infectivity and Genome Persistence of Rotavirus and Astrovirus in Groundwater and Surface Water. Water Res. 2008, 42, 2618-2628. [CrossRef] [PubMed]

264. Zannella, C.; Mosca, F.; Mariani, F.; Franci, G.; Folliero, V.; Galdiero, M.; Tiscar, P.G.; Galdiero, M. Microbial Diseases of Bivalve Mollusks: Infections, Immunology and Antimicrobial Defense. Mar. Drugs 2017, 15, 182. [CrossRef]

265. Burge, C.A.; Closek, C.J.; Friedman, C.S.; Groner, M.L.; Jenkins, C.M.; Shore-Maggio, A.; Welsh, J.E. The Use of Filter-Feeders to Manage Disease in a Changing World. Integr. Comp. Biol. 2016, 56, 573-587. [CrossRef]

266. Hernroth, B.E.; Conden-Hansson, A.-C.; Rehnstam-Holm, A.-S.; Girones, R.; Allard, A.K. Environmental Factors Influencing Human Viral Pathogens and Their Potential Indicator Organisms in the Blue Mussel, Mytilus Edulis: The First Scandinavian Report. Appl. Environ. Microbiol. 2002, 68, 4523. [CrossRef]

267. Elbashir, S.; Parveen, S.; Schwarz, J.; Rippen, T.; Jahncke, M.; DePaola, A. Seafood Pathogens and Information on Antimicrobial Resistance: A Review. Food Microbiol. 2018, 70, 85-93. [CrossRef]

268. Vasickova, P.; Pavlik, I.; Verani, M.; Carducci, A. Issues Concerning Survival of Viruses on Surfaces. Food Environ. Virol. 2010, 2, 24-34. [CrossRef]

269. Polo, D.; Varela, M.F.; Romalde, J.L. Detection and Quantification of Hepatitis A Virus and Norovirus in Spanish Authorized Shellfish Harvesting Areas. Int. J. Food Microbiol. 2015, 193, 43-50. [CrossRef] [PubMed]

270. Shuval, H. Estimating the Global Burden of Thalassogenic Diseases: Human Infectious Diseases Caused by Wastewater Pollution of the Marine Environment. J. Water Health 2003, 1, 53-64. [CrossRef]

271. Adegoke, A.A.; Amoah, I.D.; Stenström, T.A.; Verbyla, M.E.; Mihelcic, J.R. Epidemiological Evidence and Health Risks Associated With Agricultural Reuse of Partially Treated and Untreated Wastewater: A Review. Front. Public Health 2018, 6. [CrossRef] [PubMed]

272. Bogler, A.; Packman, A.; Furman, A.; Gross, A.; Kushmaro, A.; Ronen, A.; Dagot, C.; Hill, C.; Vaizel-Ohayon, D.; Morgenroth, E. Rethinking Wastewater Risks and Monitoring in Light of the COVID-19 Pandemic. Nat. Sustain. 2020, 1-10. [CrossRef]

273. Wurtzer, S.; Marechal, V.; Mouchel, J.M.; Maday, Y.; Teyssou, R.; Richard, E.; Almayrac, J.L.; Moulin, L. Evaluation of Lockdown Effect on SARS-CoV-2 Dynamics through Viral Genome Quantification in Waste Water, Greater Paris, France, 5 March to 23 April 2020. Eurosurveillance 2020, 25, 2000776. [CrossRef]

274. Sharif, S.; Ikram, A.; Khurshid, A.; Salman, M.; Mehmood, N.; Arshad, Y.; Ahmed, J.; Safdar, R.M.; Rehman, L.; Mujtaba, G.; et al Detection of SARs-CoV-2 in Wastewater Using the Existing Environmental Surveillance Network: A Potential Supplementary System for Monitoring COVID-19 Transmission. PLoS ONE 2021, 16, e0249568. [CrossRef] [PubMed]

275. La Rosa, G.; Iaconelli, M.; Mancini, P.; Ferraro, G.B.; Veneri, C.; Bonadonna, L.; Lucentini, L.; Suffredini, E. First Detection of SARS-CoV-2 in Untreated Wastewaters in Italy. Sci. Total. Environ. 2020, 736, 139652. [CrossRef]

276. Medema, G.; Heijnen, L.; Elsinga, G.; Italiaander, R.; Brouwer, A. Presence of SARS-Coronavirus-2 RNA in Sewage and Correlation with Reported COVID-19 Prevalence in the Early Stage of the Epidemic in the Netherlands. Environ. Sci. Technol. Lett. 2020, 7, 511-516. [CrossRef]

277. Rimoldi, S.G.; Stefani, F.; Gigantiello, A.; Polesello, S.; Comandatore, F.; Mileto, D.; Maresca, M.; Longobardi, C.; Mancon, A.; Romeri, F. Presence and Infectivity of SARS-CoV-2 Virus in Wastewaters and Rivers. Sci. Total. Environ. 2020, $744,140911$. [CrossRef]

278. Ahmed, W.; Angel, N.; Edson, J.; Bibby, K.; Bivins, A.; O’Brien, J.W.; Choi, P.M.; Kitajima, M.; Simpson, S.L.; Li, J. First Confirmed Detection of SARS-CoV-2 in Untreated Wastewater in Australia: A Proof of Concept for the Wastewater Surveillance of COVID-19 in the Community. Sci. Total. Environ. 2020, 728, 138764. [CrossRef] [PubMed]

279. Wu, F.; Zhang, J.; Xiao, A.; Gu, X.; Lee, W.L.; Armas, F.; Kauffman, K.; Hanage, W.; Matus, M.; Ghaeli, N. SARS-CoV-2 Titers in Wastewater Are Higher than Expected from Clinically Confirmed Cases. Msystems 2020, 5, e00614-20. [CrossRef] [PubMed]

280. Nemudryi, A.; Nemudraia, A.; Wiegand, T.; Surya, K.; Buyukyoruk, M.; Cicha, C.; Vanderwood, K.K.; Wilkinson, R.; Wiedenheft, B. Temporal Detection and Phylogenetic Assessment of SARS-CoV-2 in Municipal Wastewater. Cell Rep. Med. 2020, 1, 100098. [CrossRef] [PubMed]

281. Kocamemi, B.A.; Kurt, H.; Sait, A.; Sarac, F.; Saatci, A.M.; Pakdemirli, B. SARS-CoV-2 Detection in Istanbul Wastewater Treatment Plant Sludges. MedRxiv 2020.

282. Randazzo, W.; Truchado, P.; Cuevas-Ferrando, E.; Simón, P.; Allende, A.; Sánchez, G. SARS-CoV-2 RNA in Wastewater Anticipated COVID-19 Occurrence in a Low Prevalence Area. Water Res. 2020, 181, 115942. [CrossRef]

283. Haramoto, E.; Malla, B.; Thakali, O.; Kitajima, M. First Environmental Surveillance for the Presence of SARS-CoV-2 RNA in Wastewater and River Water in Japan. Sci. Total. Environ. 2020, 737, 140405. [CrossRef] 
284. Kumar, M.; Patel, A.K.; Shah, A.V.; Raval, J.; Rajpara, N.; Joshi, M.; Joshi, C.G. First Proof of the Capability of Wastewater Surveillance for COVID-19 in India through Detection of Genetic Material of SARS-CoV-2. Sci. Total. Environ. 2020, 746, 141326. [CrossRef]

285. Guerrero-Latorre, L.; Ballesteros, I.; Villacrés-Granda, I.; Granda, M.G.; Freire-Paspuel, B.; Ríos-Touma, B. SARS-CoV-2 in River Water: Implications in Low Sanitation Countries. Sci. Total. Environ. 2020, 743, 140832. [CrossRef] [PubMed]

286. Westhaus, S.; Weber, F.-A.; Schiwy, S.; Linnemann, V.; Brinkmann, M.; Widera, M.; Greve, C.; Janke, A.; Hollert, H.; Wintgens, T. Detection of SARS-CoV-2 in Raw and Treated Wastewater in Germany-Suitability for COVID-19 Surveillance and Potential Transmission Risks. Sci. Total. Environ. 2021, 751, 141750. [CrossRef]

287. Rodríguez-Lázaro, D.; Cook, N.; Ruggeri, F.M.; Sellwood, J.; Nasser, A.; Nascimento, M.S.J.; D’Agostino, M.; Santos, R.; Saiz, J.C.; Rzeżutka, A. Virus Hazards from Food, Water and Other Contaminated Environments. FEMS Microbiol. Rev. 2012, 36, 786-814. [CrossRef]

288. Simmons, F.J.; Xagoraraki, I. Release of Infectious Human Enteric Viruses by Full-Scale Wastewater Utilities. Water Res. 2011, 45, 3590-3598. [CrossRef] [PubMed]

289. Barrella, K.M.; Garrafa, P.; Monezi, T.A.; Hársi, C.M.; Salvi, C.; Violante, P.A.B.C.; Mehnert, D.U. Longitudinal Study on Occurrence of Adenoviruses and Hepatitis A Virus in Raw Domestic Sewage in the City of Limeira, São Paulo. Braz. J. Microbiol. 2009, 40, 102-107. [CrossRef] [PubMed]

290. Masachessi, G.; Pisano, M.B.; Prez, V.E.; Martínez, L.C.; Michelena, J.F.; Martínez-Wassaf, M.; Giordano, M.O.; Isa, M.B.; Pavan, J.V.; Welter, A. Enteric Viruses in Surface Waters from Argentina: Molecular and Viable-Virus Detection. Appl. Environ. Microbiol. 2018, 84, e02327-17. [CrossRef] [PubMed]

291. Sherchan, S.P.; Shahin, S.; Ward, L.M.; Tandukar, S.; Aw, T.G.; Schmitz, B.; Ahmed, W.; Kitajima, M. First Detection of SARS-CoV-2 RNA in Wastewater in North America: A Study in Louisiana, USA. Sci. Total. Environ. 2020, 743, 140621. [CrossRef] [PubMed]

292. Bonadonna, L.; La Rosa, G. A Review and Update on Waterborne Viral Diseases Associated with Swimming Pools. Int. J. Environ. Res. Public Health 2019, 16, 166. [CrossRef] [PubMed]

293. Wen, X.; Chen, F.; Lin, Y.; Zhu, H.; Yuan, F.; Kuang, D.; Jia, Z.; Yuan, Z. Microbial Indicators and Their Use for Monitoring Drinking Water Quality-A Review. Sustainability 2020, 12, 2249. [CrossRef]

294. Bitton, G. Wastewater Microbiology; John Wiley \& Sons: Hoboken, NJ, USA, 2005.

295. Xagoraraki, I.; Yin, Z.; Svambayev, Z. Fate of Viruses in Water Systems. J. Environ. Eng. 2014, 140, 04014020. [CrossRef]

296. Jurzik, L.; Hamza, I.A.; Puchert, W.; Überla, K.; Wilhelm, M. Chemical and Microbiological Parameters as Possible Indicators for Human Enteric Viruses in Surface Water. Int. J. Hyg. Environ. Health 2010, 213, 210-216. [CrossRef] [PubMed]

297. Ahmed, W.; Payyappat, S.; Cassidy, M.; Besley, C. Enhanced Insights from Human and Animal Host-Associated Molecular Marker Genes in a Freshwater Lake Receiving Wet Weather Overflows. Sci. Rep. 2019, 9, 1-13. [CrossRef] [PubMed]

298. Malla, B.; Makise, K.; Nakaya, K.; Mochizuki, T.; Yamada, T.; Haramoto, E. Evaluation of Human-and Animal-Specific Viral Markers and Application of Crassphage, Pepper Mild Mottle Virus, and Tobacco Mosaic Virus as Potential Fecal Pollution Markers to River Water in Japan. Food Environ. Virol. 2019, 11, 446-452. [CrossRef] [PubMed]

299. Crank, K.; Petersen, S.; Bibby, K. Quantitative Microbial Risk Assessment of Swimming in Sewage Impacted Waters Using CrAssphage and Pepper Mild Mottle Virus in a Customizable Model. Environ. Sci. Technol. Lett. 2019, 6, 571-577. [CrossRef]

300. Boehm, A.B.; Graham, K.E.; Jennings, W.C. Can We Swim yet? Systematic Review, Meta-Analysis, and Risk Assessment of Aging Sewage in Surface Waters. Environ. Sci. Technol. 2018, 52, 9634-9645. [CrossRef]

301. Symonds, E.M.; Young, S.; Verbyla, M.E.; McQuaig-Ulrich, S.M.; Ross, E.; Jiménez, J.A.; Harwood, V.J.; Breitbart, M. Microbial Source Tracking in Shellfish Harvesting Waters in the Gulf of Nicoya, Costa Rica. Water Res. 2017, 111, 177-184. [CrossRef]

302. Law, I.B. Rouse Hill-Australia'n9s First Full Scale Domestic Non-Potable Reuse Application. Water Sci. Technol. 1996, $33,71-78$. [CrossRef]

303. Kayaalp, N.M. Regulatory Framework in South Australia and Reclaimed Water Reuse Options and Possibilities. Desalination 1996, 106, 317-322. [CrossRef]

304. EPA. Guidelines for Water Reuse; EPA/625/R-04/108; US Environmental Protection Agency: Washington, DC, USA, 2004.

305. WHO. World Health Organization Guidelines for the safe use of wastewater and excreta in agriculture and aquaculture. In Guidelines for the Safe Use of Wastewater and Excreta in Agriculture and Aquaculture; WHO: Geneva, Switzerland, 1989 ; pp. 7-187.

306. Elbana, T.A.; Bakr, N.; Elbana, M. Reuse of treated wastewater in Egypt: Challenges and opportunities. In Unconventional Water Resources and Agriculture in Egypt; Springer: Berlin, Germany, 2017; pp. 429-453.

307. Ouda, O.K. Treated Wastewater Use in Saudi Arabia: Challenges and Initiatives. Int. J. Water Resour. Dev. 2016, 32, 799-809. [CrossRef]

308. Kalavrouziotis, I.K.; Kokkinos, P.; Oron, G.; Fatone, F.; Bolzonella, D.; Vatyliotou, M.; Fatta-Kassinos, D.; Koukoulakis, P.H.; Varnavas, S.P. Current Status in Wastewater Treatment, Reuse and Research in Some Mediterranean Countries. Desalination Water Treat. 2015, 53, 2015-2030. [CrossRef]

309. EPA. Guidelines for Water Reuse; EPA/600/R-12/618; EPA: Washington, DC, USA, 2012.

310. Pedrero, F.; Kalavrouziotis, I.; Alarcón, J.J.; Koukoulakis, P.; Asano, T. Use of Treated Municipal Wastewater in Irrigated Agriculture-Review of Some Practices in Spain and Greece. Agric. Water Manag. 2010, 97, 1233-1241. [CrossRef]

311. Elbana, T.A.; Ramadan, M.A.; Gaber, H.M.; Bahnassy, M.H.; Kishk, F.M.; Selim, H.M. Heavy Metals Accumulation and Spatial Distribution in Long Term Wastewater Irrigated Soils. J. Environ. Chem. Eng. 2013, 1, 925-933. [CrossRef] 
312. Ouda, O.K. Impacts of Agricultural Policy on Irrigation Water Demand: A Case Study of Saudi Arabia. Int. J. Water Resour. Dev. 2014, 30, 282-292. [CrossRef]

313. Van der Hoek, J.P.; de Fooij, H.; Struker, A. Wastewater as a Resource: Strategies to Recover Resources from Amsterdam's Wastewater. Resour. Conserv. Recycl. 2016, 113, 53-64. [CrossRef]

314. Lefebvre, O. Beyond NEWater: An Insight into Singapore's Water Reuse Prospects. Curr. Opin. Environ. Sci. Health 2018, 2, 26-31. [CrossRef]

315. Vuppaladadiyam, A.K.; Merayo, N.; Prinsen, P.; Luque, R.; Blanco, A.; Zhao, M. A Review on Greywater Reuse: Quality, Risks, Barriers and Global Scenarios. Rev. Environ. Sci. Bio/Technol. 2019, 18, 77-99. [CrossRef]

316. Oh, K.S.; Leong, J.Y.C.; Poh, P.E.; Chong, M.N.; Von Lau, E. A Review of Greywater Recycling Related Issues: Challenges and Future Prospects in Malaysia. J. Clean. Prod. 2018, 171, 17-29. [CrossRef]

317. Abrantes, S.; Silva, F.; Albuquerque, A. Technical Solutions for Water Reuse in a Social and Cultural Center. In Proceedings of the 5th Water Efficiency Conference 2018, Aveiro, Portugal, 5-7 September 2018.

318. Jumat, M.R.; Hasan, N.A.; Subramanian, P.; Heberling, C.; Colwell, R.R.; Hong, P.-Y. Membrane Bioreactor-Based Wastewater Treatment Plant in Saudi Arabia: Reduction of Viral Diversity, Load, and Infectious Capacity. Water 2017, 9, 534. [CrossRef]

319. Capocelli, M.; Prisciandaro, M.; Piemonte, V.; Barba, D. A Technical-Economical Approach to Promote the Water Treatment \& Reuse Processes. J. Clean. Prod. 2019, 207, 85-96.

320. Avni, N.; Eben-Chaime, M.; Oron, G. Optimizing Desalinated Sea Water Blending with Other Sources to Meet Magnesium Requirements for Potable and Irrigation Waters. Water Res. 2013, 47, 2164-2176. [CrossRef] [PubMed]

321. Ghermandi, A.; Minich, T. Analysis of Farmers' Attitude toward Irrigation with Desalinated Brackish Water in Israel's Arava Valley. Desalin. Water Treat. 2017, 76, 328-331. [CrossRef]

322. Al-Seekh, S.H.; Mohammad, A.G. The Effect of Water Harvesting Techniques on Runoff, Sedimentation, and Soil Properties. Environ. Manag. 2009, 44, 37-45. [CrossRef] [PubMed]

323. Van Lier, J.B.; Huibers, F.P. From Unplanned to Planned Agricultural Use: Making an Asset out of Wastewater. Irrig. Drain. Syst. 2010, 24, 143-152. [CrossRef]

324. Chien, S.-S.; Hong, D.-L.; Lin, P.-H. Ideological and Volume Politics behind Cloud Water Resource Governance-Weather Modification in China. Geoforum 2017, 85, 225-233. [CrossRef]

325. Molinos-Senante, M.; Hernandez-Sancho, F.; SalA-Garrido, R. Tariffs and Cost Recovery in Water Reuse. Water Resour. Manag. 2013, 27, 1797-1808. [CrossRef]

326. AATSE. Water Recycling in Australia; Australian Academy of Technological Sciences and Engineering: Melbourne, VIC, Australia, 2004.

327. Iglesias, R.; Ortega, E.; Batanero, G.; Quintas, L. Water Reuse in Spain: Data Overview and Costs Estimation of Suitable Treatment Trains. Desalination 2010, 263, 1-10. [CrossRef]

328. WSAA. WSAA Facts 2005. Pricing for Recycled Water; Occasional Paper No. 12; Water Services Association of Australia: Melbourne, VIC, Australia, 2005.

329. Huang, X.; Zhao, Z.; Hernandez, D.; Jiang, S.C. Near Real-Time Flow Cytometry Monitoring of Bacterial and Viral Removal Efficiencies during Water Reclamation Processes. Water 2016, 8, 464. [CrossRef]

330. Brady, N.C.; Weil, R.R.; Weil, R.R. The Nature and Properties of Soils; Prentice Hall: Upper Saddle River, NJ, USA, 2008 ; Volume 13.

331. Sparks, D.L. Environmental Soil Chemistry; Elsevier: Amsterdam, The Netherlands, 2003; ISBN 978-0-08-049480-7.

332. Bloom, P. Soil pH and pH Buffering. In Handbook of Soil Science; CRC Press: Boca Raton, FL, USA, $2000 ;$ pp. B333-B352.

333. Barker, S.F.; O’Toole, J.; Sinclair, M.I.; Leder, K.; Malawaraarachchi, M.; Hamilton, A.J. A Probabilistic Model of Norovirus Disease Burden Associated with Greywater Irrigation of Home-Produced Lettuce in Melbourne, Australia. Water Res. 2013, 47, 1421-1432. [CrossRef]

334. Rice, J.; Wutich, A.; Westerhoff, P. Assessment of de Facto Wastewater Reuse across the US: Trends between 1980 and 2008. Environ. Sci. Technol. 2013, 47, 11099-11105. [CrossRef] [PubMed]

335. Rice, J.; Westerhoff, P. Spatial and Temporal Variation in de Facto Wastewater Reuse in Drinking Water Systems across the USA. Environ. Sci. Technol. 2015, 49, 982-989. [CrossRef]

336. National Research Council. Water Reuse: Potential for Expanding the Nation's Water Supply through Reuse of Municipal Wastewater; National Academies Press: Washington, DC, USA, 2012.

337. Lim, K.-Y.; Wu, Y.; Jiang, S.C. Assessment of Cryptosporidium and Norovirus Risk Associated with de Facto Wastewater Reuse in Trinity River, Texas. Microb. Risk Anal. 2017, 5, 15-24. [CrossRef]

338. Soller, J.A.; Eftim, S.E.; Nappier, S.P. Comparison of Predicted Microbiological Human Health Risks Associated with de Facto, Indirect, and Direct Potable Water Reuse. Environ. Sci. Technol. 2019, 53, 13382-13389. [CrossRef]

339. Milly, P.C.; Dunne, K.A.; Vecchia, A.V. Global Pattern of Trends in Streamflow and Water Availability in a Changing Climate. Nature 2005, 438, 347-350. [CrossRef]

340. WHO. Water Safety Plans. Available online: https://www.euro.who.int/en/health-topics/environment-and-health/water-andsanitation/water-safety-plans (accessed on 1 June 2021).

341. Bryan, J.J. Hazard Analysis and Critical Control Points and Their Application to the Drinking Water Treatment Process. In Proceedings of the AWWA Water Quality Technology Conference, Miami, FL, USA, 7-11 November 1993; pp. $169-176$.

342. Havelaar, A.H. Application of HACCP to Drinking Water Supply. Food Control 1994, 5, 145-152. [CrossRef] 